\title{
BUKU AJAR MATA KULIAH KALKULUS
}

\author{
Oleh \\ Nuril Lutvi Azizah, S.Si., M.Si. \\ Novia Ariyanti, S.Si., M.Pd.
}

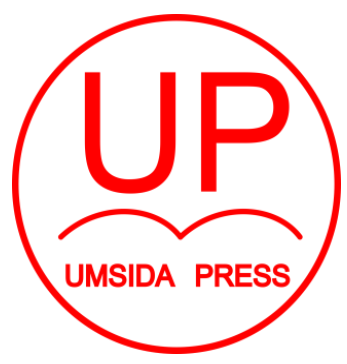

Diterbitkan oleh UMSIDA PRESS 
BUKU AJAR

\section{KALKULUS}

\section{Penulis :}

Nuril Lutvi Azizah, S.Si., M.Si.

Novia Ariyanti, S.Si., M.Pd.

\section{ISBN :}

\section{Editor :}

Septi Budi Sartika, M.Pd

M. Tanzil Multazam, S.H., M.Kn.

\section{Copy Editor :}

Fika Megawati, S.Pd., M.Pd.

\section{Design Sampul dan Tata Letak :}

Mochamad Nashrullah, S.Pd

\section{Penerbit :}

UMSIDA Press

\section{Redaksi :}

Universitas Muhammadiyah Sidoarjo

Jl. Mojopahit No 666B

Sidoarjo, Jawa TImur

\section{Cetakan pertama, Agustus 2019}

(C) Hak cipta dilindungi undang-undang

Dilarang memperbanyak karya tulis ini dengan suatu apapun tanpa ijin tertulis dari penerbit. 


\section{KATA PENGANTAR}

Puji Syukur kami panjatkan kehadirat Tuhan yang Maha Esa karena atas rahmat dan hidayah-Nya, kami dapat menyelesaikan Buku Kalkulus ini dengan baik.

Buku Kalkulus ini sengaja ditulis untuk dipergunakan sebagai acuan bagi pembaca dan mahasiswa tingkat sarjana pada program studi Teknik. Selain itu, di dalam buku ini diberikan permasalahan berupa contoh soal dan penyelesaian permasalahan, sehingga diharapkan dapat membantu dalam memberikan wawasan dan pemahaman yang lebih baik dari sebelumnya. Sementara dalam hal kedalaman dan ketajaman materi, penulis masih mengharapkan pembaca untuk membuka teks yang asli serta lebih banyak waktu untuk diskusi dan latihan soal.

Penyusun menyampaikan banyak terimakasih kepada pihak-pihak yang berkenan memberikan kritik dan saran untuk penyempurnaan buku ajar ini pada edisi berikutnya. Semoga apa yang tertuang disini akan bisa memberikan kontribusi di lingkup UMSIDA dan berperan didalam Pembangunan Nasional umumnya dan sektor industri khususnya. 


\section{DAFTAR ISI}

KATA PENGANTAR

V

DAFTAR ISI

vi

CAPAIAN PEMBELAJARAN

viii

1. BAB 1 : SISTEM BILANGAN RIIL 1

1.1. Pendahuluan Sistem Bilangan Riil 2

1.2. Bilangan Real, Selang, dan Pertidaksamaan 3

1.3. Nilai Mutlak, Akar Kuadrat, Kuadrat 10

1.4. Bidang Koordinat 16

1.5. Garis 20

1.6. Grafik dan Persamaan 23

2. BAB 2 : FUNGSI dan LIMIT 27

2.1. Fungsi 28

2.2. Operasi-Operasi Pada Fungsi 36

2.3. Grafik Fungsi 39

2.4. Pengantar Limit 44

2.5. Teknik Perhitungan Limit 47

2.6. Limit Sebagai Suatu Pendekatan 55

2.7. Kontinuitas 58

3. BAB 3 : TURUNAN 63

3.1. Laju Perubahan 64

3.2. Turunan Fungsi Aljabar 66

3.3. Turunan Fungsi Trigonometri 69

3.4. Teknik Turunan 71

3.5. Aturan Rantai 77

3.6. Turunan Fungsi Implisit $\quad 81$ 
4. BAB 4 : APLIKASI TURUNAN 85

4.1. Laju yang Berkaitan 86

4.2. Selang Naik, Selang Turun, dan Kecekungan Fungsi 93

4.3. Nilai Ekstrim 100

4.4. Nilai Maksimum dan Minimum Fungsi 102

4.5. Aplikasi Masalah Maksimum \& Minimum 105

5. BAB 5 : INTEGRASI 115

5.1. Konsep Dasar Integral 116

5.2. Integral Tak Tentu 119

5.3. Integral dengan Subsitusi 127

5.4. Integral Tertentu 131

5.5. Teorema Fundamental Kalkulus Pertama 134

5.6. Teorema Fundamental Kalkulus Kedua 136

$\begin{array}{ll}\text { DAFTAR PUSTAKA } & 138\end{array}$

$\begin{array}{ll}\text { BIODATA PENULIS } & 139\end{array}$ 


\section{CP-MK :}

1. Mahasiswa dapat mengidentifikasi permasalahan dalam bentuk system bilangan riil

2. Mahasiswa mampu memahami dan menyelesaikan fungsi dan operasi-opersi yang berkaitan dengan fungsi

3. Mahasiswa dapat menerapkan operasi fungsi pada pembahasan limit suatu fungsi

4. Mahasiswa dapat memahami, menyelesaikan dan mengidentifikasi persoalan dalam bentuk turunan fungsi

5. Mahasiswa dapat menganalisis dan menerapkan aplikasi turunan dalam permasalahan teknik.

6. Mahasiswa mampu memahami dan menyelesaikan persoalan yang berkaitan dengan integral tak tentu

7. Mahasiswa dapat menerapkan aplikasi integral dalam kaitannya dengan permasalahan teknik. 


\section{BAB 1:}

\section{SISTEM BILANGAN RIIL}

Capaian Pembelajaran Mata Kuliah :

- Mahasiswa dapat mengidentifikasi permasalahan dalam bentuk system bilangan riil 
Kalkulus merupakan cabang ilmu matematika yang mencakup masalah bilangan riil, limit, turunan, integral, dan lainnya. Istilah lain Kalkulus berarti "batu kecil" untuk menghitung. Kalkulus membahas mengenai pengertian sistem bilangan Real, klasifikasi bilangan real, dan persoalan yang berkaitan dengan sistem bilangan real. Apakah Bilangan Riil itu?

\subsection{PENDAHULUAN SISTEM BILANGAN RIIL}

Bilangan merupakan konsep di dalam matematika yang digunakan untuk perhitungan, pengukuran, dan pencacahan. Himpunan bilangan terbagi ke dalam beberapa kelompok, dan himpunan bilangan terbesar adalah bilangan kompleks $(C)$, yang memuat di dalamnya himpunan bilangan riil $(R)$. Ternyata di dalam himpunan bilangan riil juga memuat himpunan bilangan lain, seperti himpunan bilangan irrasional $(I)$, bilangan rasional $(Q)$, bilangan bulat $(Z)$, dan bilangan asli $(N)$. Berikut pada bagan dibawah ini merupakan himpunan bilangan berdasarkan kelompok bilangan.

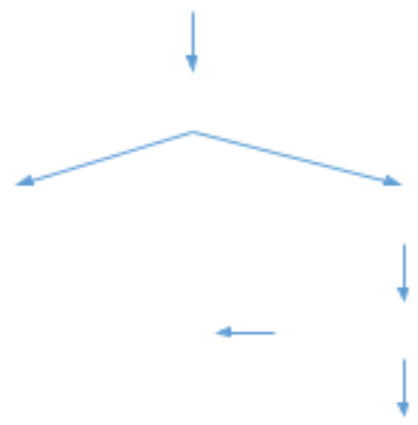

Bilangan Kompleks

Bilangan Riil 


\section{Bilangan Irrasional \\ Bilangan Rasional \\ Bilangan Bulat \\ Bilangan Asli \\ Bulat Positif \\ Bulat Negatif}

\section{Gambar 1.1. Himpunan Bilangan Riil}

\subsection{BILANGAN RIIL, SELANG, dan PERTIDAKSAMAAN}

Dari Gambar 1 diatas, bilangan Riil merupakan bilangan yang cakupan nilainya banyak dibawah bilangan kompleks. Akan tetapi kenapa disebut bilangan riil? Karena sebelumnya bilangan riil belum memiliki nama, namun setelah bilangan imajiner dipelajari, barulah muncul nama bilangan riil (nyata). Himpunan bilangan riil ini dinotasikan dengan $R$. Bilangan riil terbagi ke dalam dua bagian, yaitu bilangan rasional dan irrasional. Bilangan rasional adalah bilangan yang dapat dituliskan ke dalam bentuk $\frac{p}{q}$ dengan $q \neq 0$, sedangkan bilangan yang tidak dapat dituliskan ke dalam bentuk $\frac{p}{q}$ disebut sebagai bilangan irrasional, seperti bilangan $\pi$, konstanta $e, \sqrt{2}$ dan lain sebagainya. Himpunan bilangan rasional dinotasikan dengan $Q$, dan himpunan bilangan irrasional dinotasikan dengan $I$. Di dalam himpunan bilangan rasional juga terdapat himpunan bilangan bulat yang dinotasikan dengan $Z$, contohnya ..., $-5,-4,-3,-2,-1,0,1,2,3,4,5, \ldots$ dan di dalam himpunan bilangan bulat terdapat himpunan bilangan asli yang dinotasikan dengan $N$. Bilangan asli merupakan himpunan bilangan bulat positif tak nol, yakni $1,2,3,4,5, \ldots$

\section{BILANGAN RIIL}


Sifat Aljabar. Operasi penjumlahan dan perkalian pada himpunan bilangan riil memenuhi sifat-sifat berikut:

1. $a+b=b+a$ (Sifat komutatif terhadap penjumlahan)

2. $(a+b)+c=a=(b+c)$. (Sifat asosiatif terhadap penjumlahan)

3. Terdapat 0 di $R$ memenuhi $a+0=0+a=a$ untuk setiap $a$ di $R$. (Memiliki identitas terhadap penjumlahan)

4. Untuk setiap $a$ di $R$ terdapat $-a$ di $R$ sehingga $a+(-a)=(-a)+a=0 \quad$ (Memiliki invers terhadap penjumlahan)

5. $a \cdot b=b . a$ (Sifat komutatif terhadap perkalian)

6. (a. b). $c=a \cdot(b . c)$ (Sifat asosiatif terhadap perkalian)

7. Terdapat 1 di $R$ sehingga 1. $a=a \cdot 1=a$ untuk setiap $a \operatorname{di} R$. (Memiliki identitas terhadap perkalian)

8. Untuk setiap $a$ di $R$ terdapat $1 / a$ di $R$ sehingga a. $\frac{1}{a}=1 \cdot \frac{a}{a}=1$. (Memiliki invers terhadap perkalian)

9. $a \cdot(b+c)=a b+a c$ untuk setiap $a, b, c$ di $R$. (Sifat distributif)

Sedangkan pengurangan dan pembagian didefinisikan sebagai

$$
x-y=x+(-y)
$$

Dan

$$
\frac{x}{y}=x \div y=x \cdot y^{-1}
$$

Dengan syarat $y \neq 0$. pembagian dengan 0 tidak didefinisikan.

Bilangan real bukan nol dibedakan menjadi bilangan real positif dan negative. Kenyataan ini memungkinkan kita memperkenalkan bentuk 
hubungan lebih kecildari atau kurang dari(<) dan lebih besar dari atau lebih dari(>). Hubungan ini masing-masing didefinisikkan sebagai berikut.

didefinisikkan sebagai berikut.

Selanjutnya hubungan kurang dari atau sama dengan $(\leq)$ dan lebih dari atau sama dengan $(\geq)$ didefinisikan sebagai berikut.

\section{DEFINISI}

jika dan hanya jika negative atau nol; jika dan hanya jika positif atau nol;

Ungkapan yang mengandung $>,<, \geq$, dan $\leq$ disebut pertidaksamaan. Pertidak samaan yang melibatkan $>$ dan $<$ disebut pertidaksamaan murni, sedangkan yang melibatkan $\geq$, dan $\leq$ disebut pertidaksamaan tidak murni.

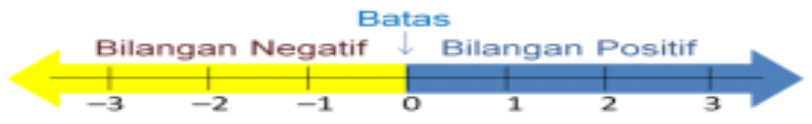

Gambar 1.2. Garis Bilangan Riil

Berdasarkan definisi, $x>0$ menyatakan bahwa $x$ merupakan bilangan positif dan, sebaliknya, $x<0$ menyatakan bahwa $x$ merpakan bilangan negative. Padagaris bilangan real, seperti pada gambar, bilangan-bilangan positif berada disebelah kanan titik 0 dan bilangan negative berada disebelah kiri titik 0 . Titik 0 disebut titik asal. Semakin ke kanan, bilangan semakin besar. Sebaliknya, semakin ke kiri bilangan semakin kecil. 
Sifat-sifat pertidaksamaan sebagai berikut.

(1) Trikotomi: Jika $x$ dan $y$ adalah bilangan, salah satu dari berikut ini akan dipenuhi: $x<y$ atau $x=y$ atau $x>y$.

(2) Transitif: Jika $x<y$ dan $y<z$ maka $x<z$.

(3) Penjumlahan: $x<y x+z<y+z$.

(4) Perkalian: Jika $z>0, x<y x z<y z$. Sebaliknya, jika $z<0, x<y x z>y z$.

\section{Selang dan Pertidaksamaan}

Perlu dipahami pula tentang intervalatau selang pada garis bilangan. Apakah yang dimaksud dengan interval atau selang? Selang merupakan himpunan bilangan real yang dibatasi oleh satu atau dua batas bilangan. Adapun beberapa selang, diantaranya adalah :

\section{a. Selang Terbuka}

Misalkan $2<\mathrm{x}<6$ ditulis $(2,6)$ artinya himpunan semua bilangan real yang lebih dari 2 dan kurang dari 6. Bilangan 2 dan 6 yang merupakan batas interval termasuk ke dalam exterior point. Interval ini apabila digambarkan pada garis bilangan akan menjadi sebagai berikut :

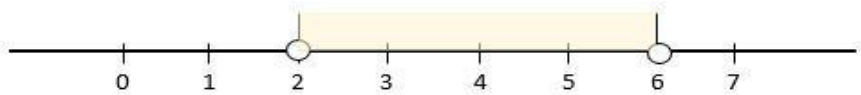

Gambar 1.3. Garis Pada Interval Terbuka

Tanda pada batas angka 2 dan 6 berupa lingkaran tanpa isi karena 2 dan 6 tidak termasuk dalam himpunan bilangan real pada interval. Tahukah kalian contoh interval terbuka yang lainnya?

\section{b. Selang Tertutup}

Misalkan interval tertutup $0 \leq x \leq \frac{7}{2}$ yaitu ditulis menjadi $\left[0, \frac{7}{2}\right]$ artinya yaitu himpunan bilangan real yang nilainya lebih dari sama dengan 0 dan kurang dari sama dengan $\frac{7}{2}$. Perbedaan dengan 
interval terbuka yaitu batas interval termasuk dalam interior point. Apabila gambarkan pada garis bilangan akan menjadi sebagai berikut.

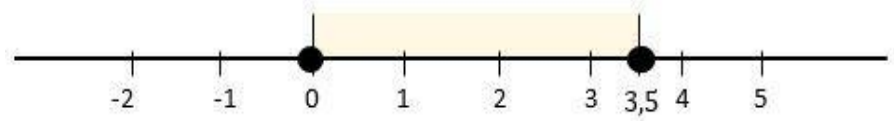

Gambar 1.4. Garis Pada Interval Tertutup

Secara umum, Suatu bilangan $x$ yang berada di antara $a$ dan $b$, yakni $a<x$ dan $x<b$, dapat dituliskan dalam pertidaksamaan bersambung sebagai berikut: $a<x<b$. Himpunan semua bilangan $x$ yang memenuhi pertidaksamaan bersambung ini disebut selang atau interval. Secara umum selang dibedakan menjadi selang terbuka, selang tertutup, dan kombinasi keduanya. Ungkapan $a<x<b$ menyatakan selang terbuka yang terdiri dari semua bilangan real antara $a$ dan $b$, tidak termasuk titik ujung $a$ dan $b$ dan lambingkan oleh $(a, b)$. Sementara itu, ungkapan $a \leq x \leq b$ menyatakan selang tertutup yang terdiri darisemua bilangan real antara $a$ dan $b$, termasuk $a$ dan $b$ itu sendiri dan dilambangkan oleh $[a, b]$. berikut ini adalah berbagai kemungkinan selang dan lambangnya.

Tabel 1. Selang dan Himpunannya 


\begin{tabular}{|c|c|c|}
\hline Lambang Himpunan & Lambang Selang & Gambar \\
\hline$\{x: a<x<b\}$ & $(a, b)$ & $\epsilon$ \\
\hline$\{x: a \leq x \leq b\}$ & {$[a, b]$} & $\underset{\mathrm{a}}{E}$ \\
\hline$\{x: a \leq x<b\}$ & {$[a, b)$} & $\underset{a}{E}$ \\
\hline$\{x: a<x \leq b\}$ & $(a, b]$ & $\epsilon_{a}$ \\
\hline$\{x: x \leq b\}$ & $(-\infty, b]$ & \\
\hline$\{x: x<b\}$ & $(-\infty, b)$ & \\
\hline$\{x: x \geq a\}$ & {$[a, \infty)$} & $E_{n}$ \\
\hline$\{x: x>a\}$ & $(a, \infty)$ & ${ }_{a}$ \\
\hline $\mathbf{R}$ & $(-\infty, \infty)$ & \\
\hline
\end{tabular}

Jenis-jenis pertidaksamaan antara lain :

1. Pertidaksamaan Linier, dan Nilai Mutlak

2. Pertidaksamaan Kuadrat

3. Pertidaksamaan Tingkat Tinggi

4. Pertidaksamaan Pecahan

5. Pertidaksamaan Bentuk Akar (Irrasional)

\section{Contoh 1.1 :}

Selesaikan pertidaksamaan dari $2+5 x<3 x-6$ !

\section{Penyelesaian :}


Dengan mengumpulkan $x$ pada salah satu sisi pertidaksamaan menjadi

$$
\begin{gathered}
2+5 x<3 x-6 \\
5 x-3 x<-6-2 \\
2 x<-8 \\
x<-4
\end{gathered}
$$

Jadi himpunan penyelesaian berupa selang $(-\infty,-4)$ yang ditunjukkan dalam gambar berikut :

$-4$

$$
\text { Gambar 1. 5. Selang }(-\infty, 4)
$$

\section{Contoh 1.2 :}

Selesaikan pertidaksamaan $4<2 x+7 \leq 3$ !

\section{Penyelesaian :}

Pertidaksamaan yang diberikan merupakan kombinasi dari dua pertidaksamaan yaitu

$4<2 x+7$ dan $2 x+7 \leq 3$

Dua pertidaksamaan tersebut dapat dikerjakan secara terpisah, kemudian ditentukan nilai $x$ yang memenuhi keduanya dengan mengambil dua irisan dua himpunan penyelesaiannya. Akan tetapi juga bisa mengkombinasikan dua dari pertidaksamaan tersebut. 
$4<2 x+7 \leq 3$

$4-7<2 x \leq 3-7 \quad$ Dikalikan dengan $\frac{1}{2}$

$-\frac{3}{2}<x \leq-\frac{4}{2} \quad$ Dibagi dengan (-1), tanda

pertidaksamaan dibalik $\frac{3}{2}>x \geq 2$

Jadi himpunan penyelesaiannya berupa selang $\left(-\infty, \frac{3}{2}\right)$ atau $[2,+\infty)$ yang ditunjukkan dalam gambar berikut :

$3 / 2$

2

Gambar 1.6. Selang $\left(-\infty, \frac{3}{2}\right)$ atau $[2,+\infty)$

\section{SOAL LATIHAN}

Selesaikan pertidaksamaan berikut dan buatlah sketsa penyelesaiannya pada garis koordinat!
a. $2+8 x \leq 2 x-10$
b. $7 \leq 3-4 x<9$
c. $-2 \geq 3-8 x \geq-11$
d. $\frac{x-3}{4+x}<2$
e. $x^{2}>16$
f. $x^{2} \leq 25$
g. $2-3 x+x^{2} \geq 0$
h. $\frac{1}{x+1}>\frac{3}{x-1}$ 


$$
\text { i. } x^{3}-3 x+2 \leq 0
$$

\subsection{NILAI MUTLAK, AKAR KUADRAT, dan KUADRAT NILAI MUTLAK}

Nilai mutlak dari bilangan real $x$, dilambangkan oleh $|x|$, didefinisikan sebagai berikut :

$$
|x|=\{x, x \geq 0-x, x<0
$$

Definisi tersebut menyatakan bahwa $|x|$ selalu bernilai taknegatif. Sebagai contoh, $|4|=4,|-3|=3,|0|=0$, dan $|-x|=|x|$.

\section{Contoh 1.3 :}

Nyatakan $|3 x-2|$ tanpa menggunakan lambang nilai mutlak!

Penyelesaian :

$|3 x-2|=\{3 x-2$ jika $3 x-2 \geq 0-(3 x-2)$, jika $3 x-2<0$

Sehingga

$$
|3 x-2|=\left\{3 x-2 \text { jika } x \geq \frac{2}{3} 2-3 x, \text { jika } x<\frac{2}{3}\right.
$$

Nilai mutlak dapat dipahami sebagai sebuah jarak. $|x|$ adalah jarak antara $x$ dan titik asal (titik nol). Dengan pemahaman yang sama, $\mid x-$ a| adalah jarak antara $x$ dan titik a.

\section{SIFAT SIFAT NILAI MUTLAK}

Misalkan $a$ dan $b$ bilangan real sembarang, dan $n$ bilangan bulat, maka :

1.

$$
\begin{array}{ll}
\text { 1. } & |a b|=|a||b| \\
\text { 2. } & \left|\frac{a}{b}\right|=\frac{|a|}{|b|},|b| \neq 0
\end{array}
$$


3. $\left|a^{n}\right|=|a|^{n}$

Misalkan $a>0$, maka :

4. $|x|=a$ jika dan hanya jika $x= \pm a$

5. $|x|<a$ jika dan hanya jika $-a<x<a$

6. $|x|>a$, jika dan hanya jika $x>a$ atau $x<-a$

Pertaksamaan $|x|<a$ mengatakan bahwa jarak dari $x$ ke titik asal adalah lebih kecil daripada $a$.

\section{Contoh 1.4 :}

Carilah himpunan penyelesaian dan ketaksamaan yang diberikan dari fungsi $\left|\frac{x}{2}-3\right|<5$ !

Penyelesaian :

$$
\left|\frac{x}{2}-3\right|<5
$$

Setara dengan,

$$
-5<\frac{x}{2}-3<5
$$

Sehingga,

$$
\begin{gathered}
-5+3<\frac{x}{2}<5+3 \\
-2(2)<x<8(2) \\
-4<x<16
\end{gathered}
$$

Jadi penyelesaiannya adalah $-4<x<16$ atau dalam selang terbuka $(-4,16)$

Contoh 1.5 :

Selesaikan $|3 x+3| \geq 1$ ! 


\section{Penyelesaian :}

$|3 x+3| \geq 1$ setara dengan $3 x+3 \geq 1$ atau

$3 x+3 \leq-1$.

Pada kasus pertama $3 x \geq-2$, memberikan penyelesaian $x \geq-\frac{2}{3}$. Dan pada kasus kedua $3 x \leq-4$, memberikan penyelesaian $x \leq-\frac{4}{3}$. Jadi himpunan penyelesaiannya adalah $\left\{x \mid x \leq-\frac{4}{3}\right.$ atau $\left.x \geq-\frac{2}{3}\right\}$ atau dengan menggunakan tanda kurung adalah $\left(-\infty,-\frac{4}{3}\right] \cup\left[-\frac{2}{3},+\infty\right)$.

\section{SOAL LATIHAN}

1. Tentukan semua nilai $x$ yang benar untuk pernyataan yang diberikan!
a. $|x-3|=3-x$
b. $\sqrt{(x+5)^{2}}=x+5$
c. $|8-2 x|=2|x-4|$

2. Carilah nilai $x$ yang memenuhi!
a. $|x-6|=5$
b. $|3 x+2|=7$
c. $|7 x+5|=|3+2 x|$
d. $2 x-7=|x+1|$
e. $\left|\frac{x+5}{3-x}\right|=5$

\section{AKAR KUADRAT}

Setiap bilangan positif memiliki dua akar kuadrat. Sebagai contoh, dua akar kuadrat dari 64 adalah 8 dan -8 dan kadang-kadang dinyatakan sebagai \pm 8 . Untuk $a \geq 0, \sqrt{a}$ disebut akar kuadrat taknegatif dari $a$. Jadi, $\sqrt{4}=2$ dan $\sqrt{225=15}$. Penulisan $\sqrt{9}= \pm 3$ 
adalah tidak benar karena $\sqrt{9}$ berarti akar kuadrat taknegatif dari 9 , yakni 3. Bilangan 3 memiliki dua akar kuadrat, yang ditulis $\pm \sqrt{3}$, tetapi $\sqrt{3}$ menyatakan bilangan real positif.

Secara umum, bentuk akar kuadrat definisikan sebagai berikut:

$$
\sqrt{x^{2}}=|x|
$$

Ingat kembali bahwa penyelesaian persamaan kuadrat $a x^{2}+b x+c=0$ diberikan oleh rumus abc sebagai berikut :

$$
x_{1,2}=\frac{-b \pm \sqrt{b^{2}-4 a c}}{2 a}
$$

Bilangan $D=b^{2}-4 a c$ disebut diskriminan dari persamaan kuadrat. Persamaan ini memiliki dua penyelesaian real jika $D=b^{2}-4 a c>0$, satu penyelesaian real jika jika $D=b^{2}-4 a c=0$, dan tak ada penyelesaian real (imajiner) jika jika $D=b^{2}-4 a c<0$.

\section{Contoh 1.6 :}

Cari penyelesaian dari $x^{2}-3 x-4=0$ !

\section{Penyelesaian :}

Apabila soal dapat dikerjakan dengan cara pemfaktoran untuk mempercepat proses penghitungan, sebagai berikut :

$$
\begin{gathered}
x^{2}-3 x-4=0 \\
(x-4)(x+1)=0
\end{gathered}
$$


Dengan demikian nilai $x=4$ atau $x=-1$, atau dengan menggunakan rumus abc :

$$
\begin{gathered}
x_{1,2}=\frac{-b \pm \sqrt{b^{2}-4 a c}}{2 a} \\
x_{1,2}=\frac{-(-3) \pm \sqrt{(-3)^{2}-4 \cdot 1 \cdot(-4)}}{2 \cdot 1}=\frac{3 \pm \sqrt{25}}{2} \\
x_{1}=\frac{3+5}{2}=4,
\end{gathered}
$$

dan

$$
x_{2}=\frac{3-5}{2}=-1
$$

Jadi penyelesaian dari persamaan diatas adalah $x=4$ dan $x=-1$.

\section{Contoh 1.7 :}

Carilah himpunan penyelesaian dari $x^{2}-3 x-4 \leq 0$ !

\section{Penyelesaian :}

Dua penyelesaian dari fungsi diatas adalah $x=4$ dan $x=-1$ seperti pengerjaan pada contoh 4. Akan tetapi perbedaan penyelesaian antara pertidaksamaan dan persamaan adalah seperti dibawah ini :

Titik pemecahan selang dibagi menjadi 3 bagian yaitu selang $(-\infty,-1],[-1,4]$, dan $[4,+\infty)$. Kemudian ambil titik uji coba diantara ketiga selang tersebut.

Pada selang $(-\infty,-1]$, ambil titik uji coba misalkan -2 , kemudian masukkan titik kedalam peersamaan awal $x^{2}-3 x-4 \leq 0$, dihasilkan nilai $(-2)^{2}-3(-2)-4=6$, didapatkan nilai 6 dan 6 
merupakan nilai yang lebih besar $\geq 0$, sehingga selang pertama tidak memenuhi.

Pada selang $[-1,4]$, ambil titik uji coba misalkan 0 , kemudian masukkan titik kedalam persamaan awal $x^{2}-3 x-4 \leq 0$, dihasilkan nilai -4 , dan -4 merupakan nilai yang lebih kecil dari $\leq 0$, sehingga selang kedua memenuhi.

Pada selang $[4,+\infty)$, ambil titik uji coba misalkan 5 , kemudian masukkan kedalam persamaan awal $x^{2}-3 x-4 \leq 0$, dihasilkan nilai 6 , dan nilai $6 \geq 0$, sehingga selang ketiga tidak memenuhi.

Dari hasil uji coba selang diatas, maka hasil yang memenuhi adalah pada himpunan $[-1,4]$ atau dengan menuliskan pada himpunan penyelesaian sebagai berikut $\{x \mid-1 \leq x \leq 4, x \in R\}$.

\section{KUADRAT}

Operasi pengkuadratan secara umum tidak mempertahankan ketaksamaan. Sebagai contoh, $-4<1$ akan tetapi $(-4)^{2}>1$, tetapi apabila yang dilakukan adalah untuk bilangan positif (tak negatif), maka operasi kuadarat tetap mempertahankan ketaksamaan $a<b \Leftrightarrow a^{2}<b^{2}$.

Salah satu bentuk lain dari persamaan kuadrat ini adalah sebagai berikut :

$$
|x|<|y| \Leftrightarrow x^{2}<y^{2}
$$

\section{Contoh 1.8:}

Selesaikan pertidaksamaan $\frac{1}{2}|3 x+12|>|x-6|$ ! 
Penyelesaian :

$$
\begin{gathered}
\frac{1}{2}|3 x+12|>|x-6| \\
|3 x+12|>2|x-6| \\
|3 x+12|>|2 x-12| \\
(3 x+12)^{2}>(2 x-12)^{2} \\
9 x^{2}+72 x+144>4 x^{2}-48 x+144 \\
5 x^{2}+120 x>0 \\
5 x(x+60)>0
\end{gathered}
$$

Titik pemecahan untuk pertidaksamaan kuadrat ini adalaha $x=-60$, dan $x=0$. Titik ini membagi garis menjadi tiga selang $(-\infty,-60),(-60,0)$, dan $(0,+\infty)$. Setelah diuji ditemukan bahwa titik-titik dalam selang $(-\infty,-60)$ dan $(0,+\infty)$ yang memenuhi pertidaksamaan tersebut.

\section{SOAL LATIHAN}

Selesaikan nilai $\mathrm{x}$, dan nyatakan penyelesaiannya dalam bentuk selang!
a. $\mid 2 x+3\}<5$
b. $|7 x+1| \geq 3$
c. $\left|\frac{1}{2} x-1\right| \leq 2$
d. $\frac{2}{|x+3|}<2$
e. $\frac{1}{|3 x+3|} \geq 4$ 


\subsection{BIDANG KOORDINAT}

Untuk menggambarkan kedudukan dari suatu titik, diperlukan suatu acuan yaitu sistem koordinat yang biasa disebut koordinat Cartesius, yang namanya diambil dari nama penggagasnya yaitu Rene Descartes. Kemudian ilmuwan lain yaitu Pierre de Fermat menggagas lebih dalam mengenai koordinat ini.

Dalam Geometri analitik, bilangan real dinyatakan dngan titik pada sebuag garis, hal ini dilakukan dengan menandai salah satu dari dua arah sepanjang garis sebagai arah positif dan arah negatif. Arah positif biasanya diberi anak panah, seperti pada gambar berikut ini :

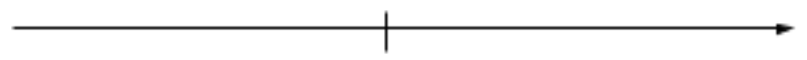

Arah negatif (-)

Arah negatif $(+)$

Titik Awal

Gambar 1.7. Garis Dalam Geometri Analitik Koordinat Cartesius

Sumbu diagram terdiri dari dua garis yang berpotongan tegak lurus. Garis yang mendatar disebut sumbu $x$ dan yang tegak disebut sumbu $y$. Titik potong sumbu $x$ dan $y$ disebut titik asal. Titik ini dinyatakan sebagai titik nol. Pada sumbu $x$ dan sumbu y terletak titik yang berjarak sama. 
Pada sumbu $\mathrm{x}$ dari titik nol ke kanan dan seterusnya merupakan bilangan positif, sedangkan dari titik nol ke kiri dan seterusnya merupakan bilangan negatif. Pada sumbu y, dari titik nol ke atas merupakan bilangan positif, dan dari titik nol ke bawah merupakan bilangan negatif.

Setiap titik pada bidang cartesius dihubungkan pada jarak tertentu ke sumbu $x$ yang disebut absis, sedangkan jarak tertentu ke sumbu $y$ disebutordinat. Absis dan ordinat mewakili pasangan bilangan (pasangan berurut) yang disebut koordinat. Penulisan koordinat ditulis dalam tanda kurung. Koordinat $x$ selalu ditulis terlebih dahulu diikuti tanda koma dan kemudian koordinat $y$.

Garis tegak lurus pada bidang cartesius, membagi bidang menjadi empat bagian, yang dinamakan kuadran, yaitu kuadran 1, kuadran 2, kuadran 3, dan kuadran 4. Pada kuadran 1 nilai $x$ dan y positif, pada kuadran 2 nilai $x$ negatif dan nilai y positif, pada kuadran 3 nilai $x$ negatif dan nilai y negatif, dan pada kuadran 4 nilai $x$ positif dan nilai y negative.

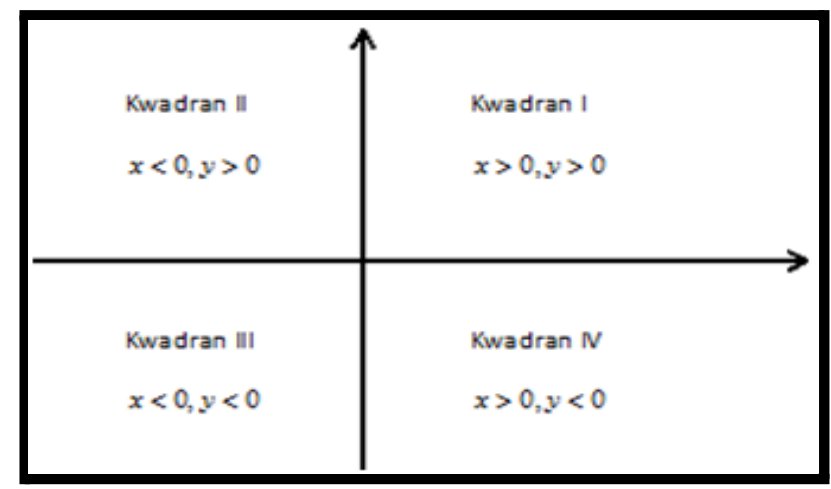

Gambar 1.8. Empat Bagian Bidang Koordinat Cartesius

Berikut ini merupakan contoh Titik-titik dalam koordinat Cartesius : 


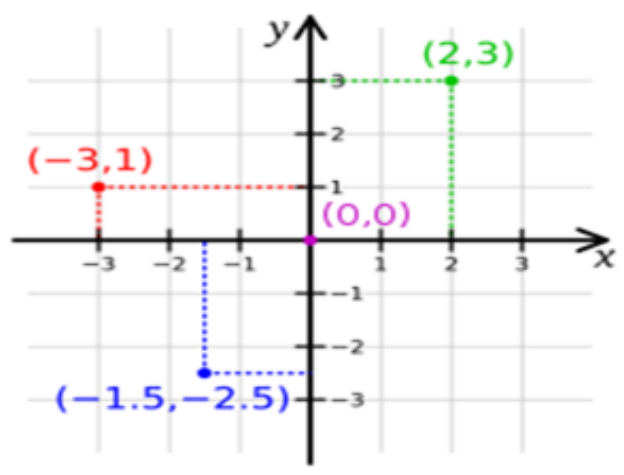

Gambar 1.9. Titik Dalam Koordinat Cartesius

Dengan memakai bidang koordinat, letak suatu titik atau benda akan ditentukan oleh pasangan koordinatnya. Misalnya pada gambar diatas :

Titik warna merah terletak pada koordinat $(-3,1)$.

Titik warna biru terletak pada koordinat $(-1.5,-2.5)$.

Titik warna hijau terletak pada koordinat $(2,3)$

Berikut contoh cara menggambar garis lurus atau grafik fungsi linier Pertama dibuat daftar terlebih dahulu.

Tabel 2. Ploting Titik-Titik Untuk Membuat Garis

\begin{tabular}{|c|c|c|c|}
\hline$X$ & $Y$ & $(X, Y)$ & Titik \\
\hline 2 & 3 & $(2,3)$ & $U$ \\
\hline 1 & 2 & $(1,2)$ & $T$ \\
\hline 0 & 1 & $(0,1)$ & $S$ \\
\hline-1 & 0 & $(-1,0)$ & $R$ \\
\hline-2 & -1 & $(-2,-1)$ & $Q$ \\
\hline-3 & -2 & $(-3,-2)$ & $P$ \\
\hline
\end{tabular}


Dari daftar di atas ini tampak bahwa titik-titik yang menghubungkan satu garis lurus adalah titik-titik $P(-3,-2), Q(-2,-1), R(-1,0), S(0,1)$, $\mathrm{T}(1,2), \mathrm{U}(2,3)$, sehingga tampak pada Gambar 10 berikut:
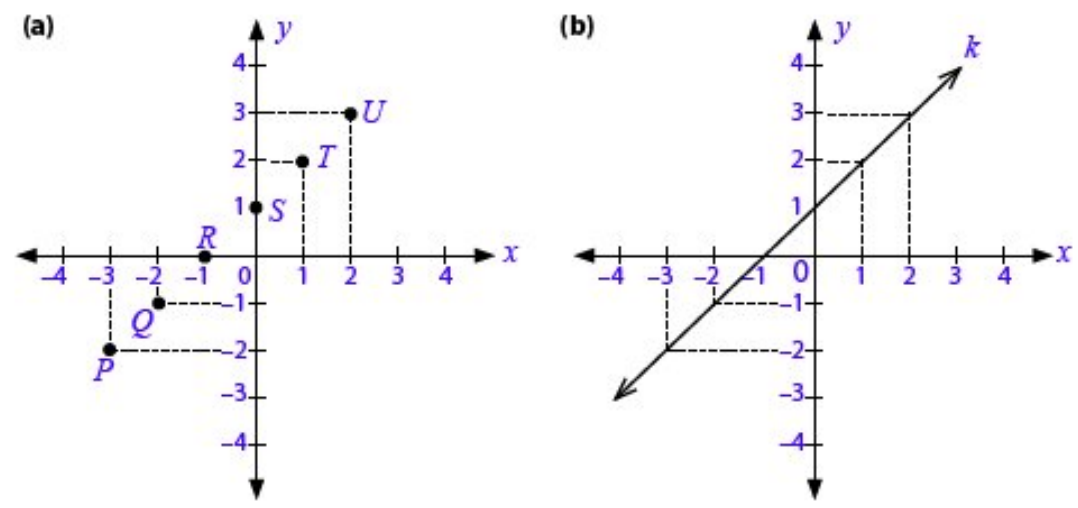

Gambar 1.10. Garis Pada Bidang Koordinat Cartesius

\subsection{GARIS}

\section{GARIS LURUS}

Garis lurus merupakan kurva sederhana yang merupakan objek dimensi 2 (objek geometri). Garis dibentuk oleh minimal 2 titik pada bidang koordinat. Dan apabila ditempatkan pada suatu koordinat bidang, garis tersebut mempunyai persamaan. Misalkan titik $A\left(x_{1}, y_{1}\right)$ dan $B\left(x_{2}, y_{2}\right)$, maka untuk menentukan suatu garis lurus hanya dengan menghubungkan titik-titik tersebut. Dengan demikian tidak ada dua garis yang berimpit yang memiliki persamaan yang sama.

\section{Contoh 1.9 :}


Pada bidang koordinat gambarlah titik-titik $(x, y)$, yaitu pada titik-titik yang koordinat $\mathrm{x}$ dan koordinat $\mathrm{y}$ yang memenuhi persamaan $\mathrm{x}+\mathrm{y}=$ 4 dengan $x=-2,1,0,1,2$, dan 3 .

\section{Penyelesaian :}

Titik-titik $(x, y)$ yang koordinat $x$ dan koordinat $y$ nya memenuhi persamaan $x+y=4$ dengan $x=-2,-1,0,1,2$ dan 3 dapat diperoleh dengan lebih dulu membuat daftar berikut:

Tabel 3. Ploting Garis

\begin{tabular}{|c|c|c|c|c|}
\hline $\begin{array}{c}\text { Persamaan } \\
x+y=4\end{array}$ & $\begin{array}{c}\text { Koordinat } \\
X\end{array}$ & $\begin{array}{c}\text { Koordinat } \\
Y\end{array}$ & $\begin{array}{c}\text { Titik-titi } \\
\mathrm{k} \\
(x, y)\end{array}$ & $\begin{array}{c}\text { Nama } \\
\text { Titik }\end{array}$ \\
\hline$-2+6=4$ & -2 & 6 & $(-2,6)$ & $\mathrm{F}$ \\
\hline$-1+5=4$ & -1 & 5 & $(-1,5)$ & $\mathrm{E}$ \\
\hline $0+4=4$ & 0 & 4 & $(0,4)$ & $\mathrm{D}$ \\
\hline $1+3=4$ & 1 & 3 & $(1,3)$ & $\mathrm{C}$ \\
\hline $2+2=4$ & 2 & 2 & $(2,2)$ & $\mathrm{B}$ \\
\hline $3+1=4$ & 3 & 1 & $(3,1)$ & $\mathrm{A}$ \\
\hline
\end{tabular}

Dari daftar di atas ini tampak bahwa titik-titik $(x, y)$ yang koordinat $x$ dan koordinat y nya memenuhi persamaan $x+y=4$, dengan $x=-2,-1$, $0,1,2$, dan 3 adalah titik-titik $F(-2,6), E(-1,5), D(0,4), C(1,3), B(2$, $2), A(3,1)$, sehingga gambarnya tampak dalam gambar berikut:
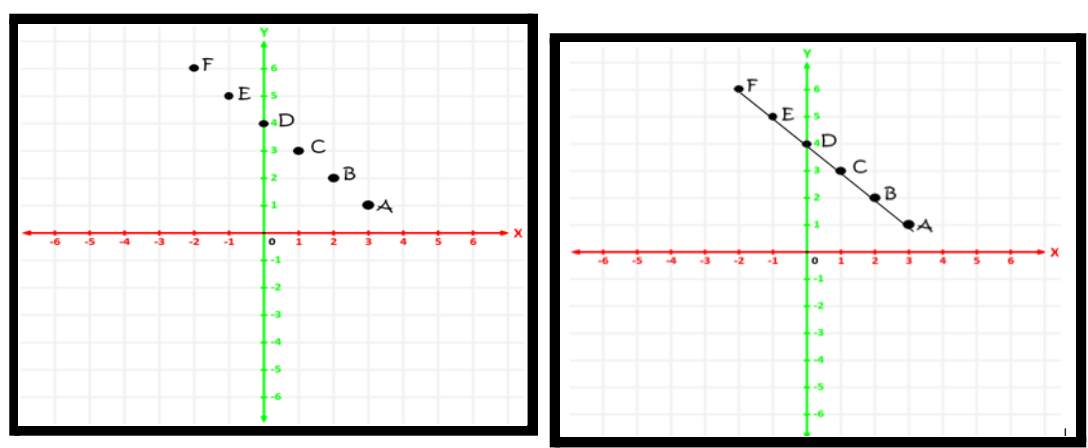
Pada umumnya, untuk membentuk suatu garis hanya dibutuhkan dua titik saja. Seperti pada Gambar 6., garis dapat dibentuk melalui titik $A\left(x_{1}, y_{1}\right)$ dan $B\left(x_{2}, y_{2}\right)$, atau $B\left(x_{2}, y_{2}\right)$ dan $C\left(x_{3}, y_{3}\right)$, dan lainnya. Kemiringan $m$ dari garis itu didefinisakn oleh :

$$
m=\frac{\Delta y}{\Delta x}=\frac{y_{2}-y_{1}}{x_{2}-x_{1}}
$$

Kemiringan atau gradien merupakan ukuran kecuraman suatu garis. Seperti pada Gambar 6 diatas, kemiringan garis tersebut adalah misalkan kita ambil titik misalnya titik $A(3,1)$ dan titik $F(-2,6)$, dengan demikian :

$$
m=\frac{\Delta y}{\Delta x}=\frac{y_{2}-y_{1}}{x_{2}-x_{1}}=\frac{6-1}{-2-3}=\frac{5}{-5}=-1
$$

Kemiringan garis menghadap kanan adalah positif, untuk kemiringan garis yang menghadap ke kiri adalah negatif. Dengan melihat kembali Gambar 6, garis menghadap ke kiri sehingga kemiringannya adalah negatif atau $m=-1$. Berikut pada Tabel 3 merupakan tabel yang membentuk persamaan garis :

Tabel 4. Bentuk-Bentuk Persamaan Garis

\begin{tabular}{|l|c|c|}
\hline \multicolumn{1}{|c|}{ Bentuk Garis } & Persamaan Umum & Keterangan \\
\hline Bentuk Standart & $\mathrm{A} x+\mathrm{B} y+\mathrm{C}=0$ & $\mathrm{~A}, \mathrm{~B}$, Konstanta tak Nol \\
\hline Kemiringan Garis & $\mathrm{y}=\mathrm{m} \mathrm{x}+\mathrm{b}$ & $\begin{array}{c}\mathrm{m}=\text { kemiringan, } \\
\text { memotong sumbu } \mathrm{y} d \mathrm{di} \\
(0, \mathrm{~b})\end{array}$ \\
\hline Kemiringan Titik & $\mathrm{y}=\mathrm{m}(\mathrm{x}-\mathrm{h})+\mathrm{k}$ & $\begin{array}{c}\mathrm{m}=\text { kemiringan, melalui } \\
\text { titik }(\mathrm{h}, \mathrm{k})\end{array}$ \\
\hline $\begin{array}{l}\text { Garis horizontal } \\
\text { (mendatar) }\end{array}$ & $\mathrm{x}=\mathrm{k}$ & \begin{tabular}{c} 
Kemiringannya $=0$ \\
\hline
\end{tabular} \\
\hline
\end{tabular}




\begin{tabular}{|l|c|c|}
\hline Garis Vertikal (tegak) & $\mathrm{x}=\mathrm{h}$ & $\begin{array}{c}\text { Tidak mempunyai } \\
\text { kemiringan (tak } \\
\text { terdefinisi) }\end{array}$ \\
\hline
\end{tabular}

\subsection{GRAFIK DAN PERSAMAAN}

Pengunaan koordinat Cartesius untuk mendeskripsikan titik-titik pada bidang ternyata memungkinkan kita untuk mendeskripsikan juga suatu kurva dengan menggunakan suatu persamaan. Nah, grafik persamaan dalam bentuk dan ini terdiri atas titik-titik yang koordinatnya memenuhi persamaan tersebut. Sebagaimana pertidaksamaan, grafik suatu persamaan dapat digambarkan. Sebelum kita mencoba menggambarkan suatu persamaan dalam koordinat Cartesius, ada tiga langkah yang akan memudahkan kita menggambarkan grafik. Apa saja?

1. Buatlah tabel nilai dari koordinat-koordinat titik yang memenuhi persamaan

2. Plotkan titik-titik tersebut

3. Hubungkan titik-titik tersebut sehingga menjadi suatu kurva yang mulus

\section{Contoh 1.10 :}

Buatlah sketsa grafik dari $y=-x^{2}+4 x-3$ !

\section{Penyelesaian :}

- Titik potong grafik dengan sumbu $x \rightarrow y=0$

Bagi semua fungsi dengan (-1), sehingga persamaan menjadi :

$$
x^{2}-4 x+3=0
$$

Dengan mencari nilai $x_{1}$ dan $x_{2}$ menggunakan pemfaktoran atau rumus abc didapatkan nilai :

$$
(x-3)(x-1)=0
$$


$x=3$ atau $x=1$

Pada koordinat Cartesius bisa dituliskan dengan $(1,0)$ dan $(3,0)$

- Titik potong grafik dengan sumbu $\mathrm{y} \rightarrow \mathrm{x}=0$

$y=-3 \rightarrow(0,-3)$

Persamaan sumbu simetri:

$x=-\frac{b}{2 a}$

$x=-\frac{(-4)}{2(1)}=2$

Koordinat titik puncak $P\left(-\frac{b}{2 a}, \frac{-D}{4 a}\right)$,

$D=b^{2}-4 a c$

$D=(-4)^{2}-4 \cdot(-1)(-3)=16-12=4$

Sehingga koordinat titik puncak grafik persamaan kuadrat ini adalah : $\frac{-D}{4 a}=1 \rightarrow P(2,1)$

Gambar grafik Persamaan :

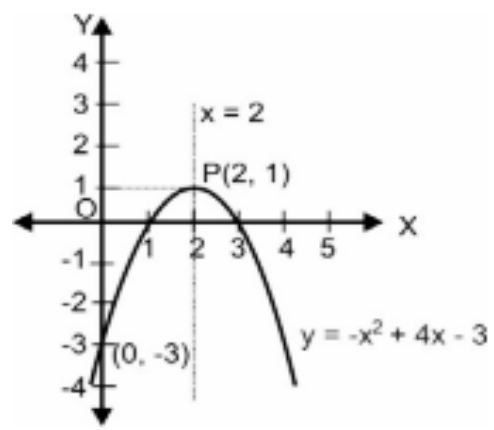

Gambar 1.12. Grafik Persamaan Kuadat $y=-x^{2}+4 x-3$

\section{Contoh 1.11 :}

Buatlah sketsa grafik persamaan $y=\sqrt{4-x^{2}}$ ! 


\section{Penyelesaian :}

Persamaan diatas dapat diubah kedalam persamaan $x^{2}+y^{2}=4$, yang merupakan persamaan dari suatu lingkaran dengan titik pusat di $(0,0)$ dan jari-jari lingkaran 2.

Persamaan umum lingkaran sebagai berikut :

$$
(x-a)^{2}+(y-b)^{2}=r^{2}
$$

Sehingga gambar lingkaran yang dimaksud sebagai berikut :

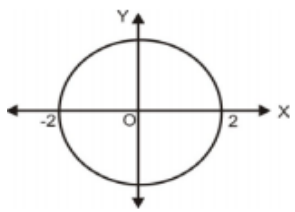

Gambar 1.13. Grafik Persamaan Lingkaran dengan jari-jari 2

\section{Contoh 1.12 :}

Buatlah sketsa grafik persamaan $\frac{x^{2}}{16}+\frac{y^{2}}{9}=1$ !

\section{Penyelesaian :}

Jika dilihat lagi, persamaan merupakan ellips dengan setengah sumbu panjang 4 , dan setengah sumbu pendek 3 , dan dengan titik pusat $(0,0)$. Berikut ini merupakan gambar ellips yang dimaksud :

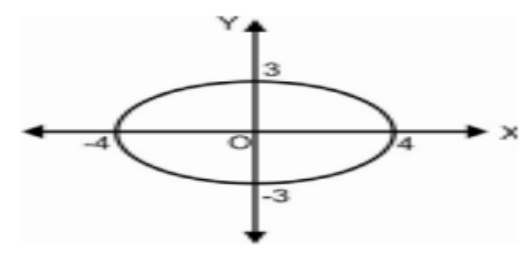

Gambar 1.14.

Persamaan Ellips

\section{Contoh 1.13 :}

Buatlah sketsa grafik persamaan $y=2 x$ ! 


\section{Penyelesaian :}

Pasangan nilai $x$ dan y yang memenuhi persamaan $y=2 x$.

Tabel 5. Ploting Titik $y=2 x$

\begin{tabular}{|l|l|l|}
\hline$X$ & $Y$ & Koordinat \\
\hline 0 & 0 & $(0,0)$ \\
\hline 1 & 2 & $(1,2)$ \\
\hline 2 & 4 & $(2,4)$ \\
\hline-1 & -2 & $(-1,-2)$ \\
\hline-2 & -4 & $(-2,-4)$ \\
\hline
\end{tabular}

Titik-titik $(0,0),(1,2)$, dan $(2,4)$

- Dua garis tegak dikatakan sejajar jika dan hanya jika keduanya mempunyai kemiringan yang sama.

- Dua garis dengan kemiringan $m_{1}$ dan $m_{2}$ dikatakan tegak lurus, jika dan hanya jika $m_{1} m_{2}=-1$, yaitu kemiringan yang satu merupakan negatif kebalikan yang lain yaitu $m_{2}=\frac{1}{m_{1}}$.

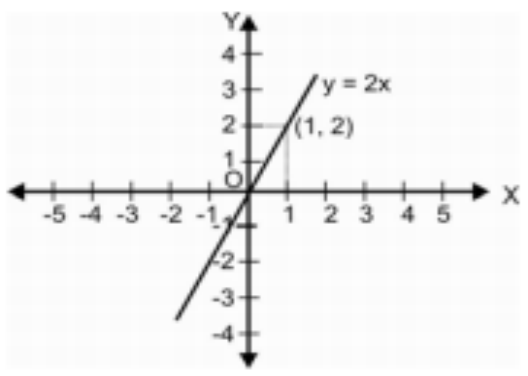

Gambar 1.15. Grafik Persamaan Linier $y=2 x$

Seperti pada Gambar 13 diatas, kemiringan garis tersebut dapat diketahui dari rumus kemiringan yaitu $y=m x+b$ yaitu 2. Berikut merupakan beberapa contoh sketsa grafik linier :

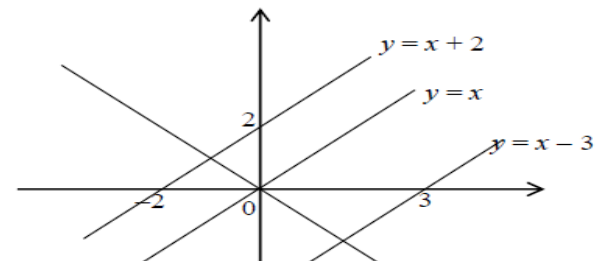


Gambar 1.16. Grafik Linier Lainnya

\section{BAB 2 :}

FLIFIESI

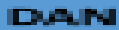

LIPMIT

Capaian Pembelajaran Mata Kuliah :

Mahasiswa

mampu

memahami dan

menyelesaikan fungsi dan

operasi-opersi yang

berkaitan dengan fungsi

Mahasiswa dapat

menerapkan operasi

fungsi pada permbahasan

limit suatu fungsi 


\subsection{FUNGSI}

Apa itu fungsi? Pengertian "fungsi" pertama kali digunakan oleh Leibniz tahun 1673 untuk menyatakan ketergantungan suatu besaran pada besaran yang lainnya, berikut ini merupakan beberapa contohnya :

1. Luas lingkaran adalah $A=\pi r^{2}$, sehingga dapat dikatakan bahwa "A adalah fungsi dari $r$ ".

2. Ada himpunan $A$ dan B bila setiap elemen dari A dikaitkan dengan suatu kaitanyang khusus dengan setiap elemen di $B$ dan kaitan tersebut mempunyai syarat atauaturan-aturan yang khusus, maka kaitan tersebut disebut "Fungsi".

Jika $f$ adalah fungsi yang memetakan dari $A$ ke $B$, maka dapat ditulis $f: A \rightarrow B$ yang artinya $f$ memetakan dari A ke B. A disebut daerah asal (domain) dan B disebut daerah hasil (Kodomain) dari $f$.

Konsep fungsi, erat kaitannya dengan relasi suatu fungsi. Relasi merupakan himpunan pasangan terurut yang merupakan himpunan dari produk kartesius antara grup dan sub grup. Fungsi juga merupakan suatu relasi, akan tetapi konsep fungsi lebih sempit daripada relasi. Syarat Fungsi antara lain : 
a. Unsur dari A harus seluruhnya muncul dalam pasangan terurut

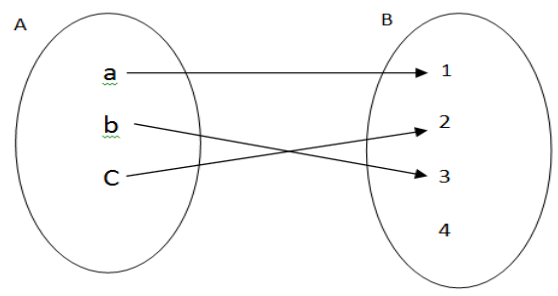

Gambar 2.1. Fungsi A B

Unsur A tidak seluruhnya muncul maka tidak bisa disebut sebagai fungsi :

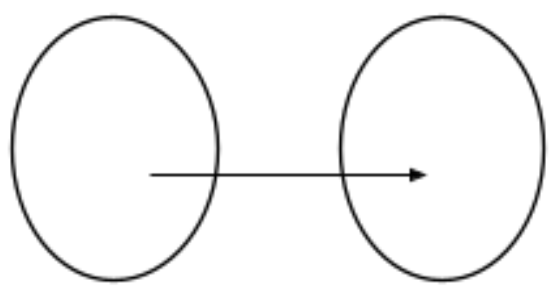

a

b

1

2

3

A

B

Gambar 2.2. Bukan Fungsi 
b. Unsur A tidak boleh muncul dua kali atau lebih dari satu kali dalam pasangan terurut

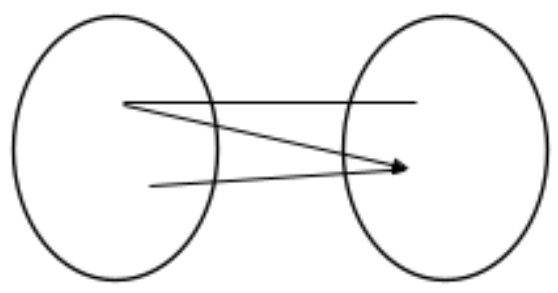

a

b

1

2

3

A

B

Gambar 2.3. Bukan Fungsi

c. Berikut merupakan relasi dan fungsi

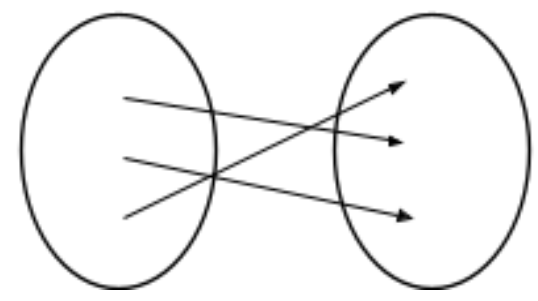

a

b 
B

Gambar 2.4. Fungsi dan Relasi

\section{Contoh 2.1. :}

Manakah relasi dibawah ini yang merupakan fungsi, jika relasi dari $\mathrm{A}$ ke B!
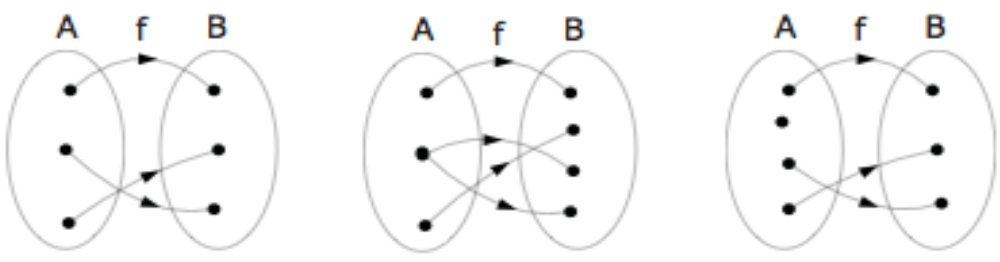

Gambar 2.5. Relasi dari A ke B

\section{Penyelesaian :}

Relasi pertama merupakan fungsi, karena setiap anggota domain A berelasi tunggal terhadap anggota kodomain B

Relasi kedua bukan merupakan fungsi, karena ada anggota domain A yang berelasi tidak tunggal terhadap anggota kodomain $B$ 
Relasi ketiga bukan merupakan fungsi, karena ada anggota domain A yang tidak berelasi dengan anggota kodomain $\mathrm{B}$

\section{DOMAIN FUNGSI (DAERAH ASAL)}

Apa yang dimaksud daerah asal fungsi atau domain fungsi? Domain sebuah fungsi merupakan sekumpulan angka yang dapat dimasukkan ke dalam suatu fungsi, atau biasa disebut sebagai daerah asal fungsi. Atau bisa jadi sekumpulan nilai $x$ yang dapat dimasukkan ke dalam fungsi apapun yang diberikan. Daerah asal dinotasikan dengan $D_{f}$. Lalu bagaimana cara menentukan domain suatu fungsi? Ada dua cara untuk menentukan domain suatu fungsi, yaitu dengan menggunakan grafik, dan tidak menggunakan grafik. Untuk lebih jelasnya, perhatikan contoh berikut:

\section{Contoh 2.2. :}

Sketsa grafik fungsi dari $f(x)=\sqrt{x+4}$. Kemudian berdasarkan grafik tersebut tuliskan domain fungsi dari $f(x)$ !

\section{Penyelesaian :}

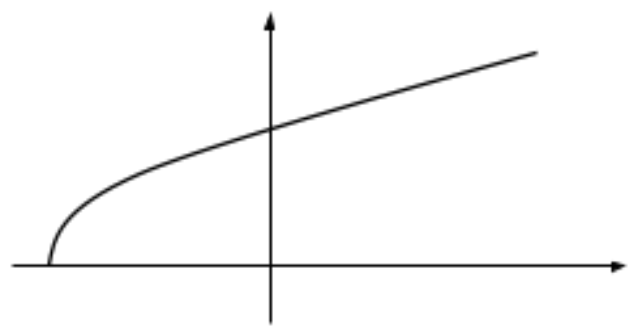


Gambar 2.6. Grafik Fungsi $f(x)=\sqrt{x+4}$

Sekarang kita fokus terhadap sumbu-x, terlihat bulatan penuh di titik $(-4,0)$, yang artinya, di titik tersebut grafik $f(x)=\sqrt{x+4}$ 'dimulai'. Oleh karena itu, daerah asalnya adalah semua nilai $x$ yang lebih besar atau sama dengan 4 , dituliskan $D=\{x \mid x \geq 4, x \in R\}$. Apa yang terjadi jika kita menginputkan nilai $x$ yang bukan anggota dari daerah asalnya ke dalam fungsi $f(x)$ ? Misal kita coba ambil nilai $x=-5$, maka jika kita substitusikan nilai tersebut ke dalam fungsi $f(x)=\sqrt{x+4}$ didapat :

$$
f(-5)=\sqrt{-5+1}=\sqrt{-1}=\text { ? }
$$

jika kita hitung nilai dari $\sqrt{-1}$ ke dalam kalkulator, maka hasilnya adalah syntax error! Jadi fungsi $f(x)=\sqrt{x+4}$ tidak dapat terdefinisikan di titik $x=-5$, begitupun untuk setiap nilai $x<4$.

Beberapa macam domain dan penyelesaiannya sebagai berikut :
a. Domain Alami (Natural)
b. Domain Fungsi Rasional
c. Domain Fungsi Irrasional

\section{a. Domain Alami (Natural)}

Domain alami merupakan domain yang muncul secara akami dari fungsi atau objek matematika, dan tidak muncul karena persoalan geometri atau fisis. Untuk domain seperti ini terjadi karena pembatasan pada fungsi matematika sudah didefinisikan terlebih dahulu sehingga domain secara alami muncul atau biasanya dari rumus yang digunakan pada fungsi atau soal.

\section{Contoh 2.3. :}

Dapatkan domain dari fungsi berikut ini :

$$
f(x)=\frac{1}{(x-2)(x+3)}
$$




\section{Penyelesaian :}

Fungsi $x$ tidak terdefinisi di $x=2$ atau $x=-3$, sebab pembagian oleh nol menyebabkan nilai fungsi tidak terdefinisi. Sedangkan untuk nilai yang lainnya, fungsi $f$ terdefinisi dan mempunyai nilai real. Jadi Domain $f$ adalah semua nilai atau bilangan real $x$ kecuali $x=2$ atau $x=-3$. Dalam notasi selang domainnya adalah :

$$
(-\infty,-3) \cup(-3,2) \cup(2,+\infty)
$$

Dapat dinyatakan dengan garis bilangan sebagai berikut :

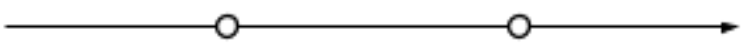

Gambar 2.7. Selang $x \neq-3,2$

\section{b. Fungsi Rasional}

Fungsi rasional $(Q)$ adalah fungsi yang dituliskan dalam bentuk pecahan $f(x)=\frac{P(x)}{Q(x)}$ dengan $P(x)$, dan $Q(x)$ merupakan polinomial, dan $Q(x) \neq 0$ (syarat agar fungsi Rasional terdefinisi adalah penyebut tidak boleh bernilai nol).

\section{Contoh 2.4. :}

Tentuka domain dari $f(x)=\frac{x^{2}-2}{x^{2}-1}$ !

\section{Penyelesaian :}

Perhatikan bahwa $f(x)=\frac{x^{2}-2}{x^{2}-1}$ dapat dibentuk kedalam $f(x)=\frac{x^{2}-2}{x^{2}-1}=\frac{x^{2}-2}{(x+1)(x-1)}$. Untuk melihat nilai domain dari fungsi tersebut, kita hanya perlu melihat bagian penyebut. 
Penyebut akan bernilai nol jika nilai $x=-1$ dan $x=1$. Jadi kita harus mengecualikan nilai $x=-1$ dan $x=1$ dari domain (daerah asal), sehingga domainnya adalah

$$
D=\{x \mid x \neq-1 \cap x \neq 1, x \in R\}
$$

Atau dengan menggunakan notasi selang, domainnya adalah :

$$
(-\infty,-1) \cup(-1,1) \cup(1,+\infty)
$$

Dapat dinyatakan dengan garis bilangan sebagai berikut :

Gambar 2.8. Selang $x \neq-1,1$

c. Domain Fungsi Irrasional

Fungsi Irrasional adalah fungsi yang berbentuk $f(x)=\sqrt[n]{g(x)}, n \in N$. Misalkan diberikan fungsi $f(x)=\sqrt{x-4}$ atau $f(x)=\sqrt[5]{2 x^{3}-2 x+1}$, jika $n=$ genap, maka syarat agar fungsi Irrasional tersebut terdefinisi adalah $g(x) \geq 0$, dan jika $n=$ ganjil, maka domain dari fungsi $f(x)$ adalah untuk setiap $x \in R$.

\section{Contoh 2.5 :}

Dapatkan Domain dari fungsi $G(x)=\sqrt{x^{2}-2 x-3}$ !

\section{Penyelesaian :}

Ingat bahwa $f(x)=\sqrt{x^{2}-2 x-3}=\sqrt[2]{x^{2}-2 x-3}$

Karena $n=2$ (genap), maka syarat agar fungsi $f(x)=\sqrt{x^{2}-2 x-3}$ terdefinisi adalah $x^{2}-2 x-3 \geq 0$. 
Kemudian kita tentukan penyelesaian nilai $x$ yang memenuhi pertidaksamaan tersebut,

$$
x^{2}-2 x-3 \geq 0
$$

$$
\begin{aligned}
& (x-3)(x+1) \geq 0 \\
& \quad x \geq 3 \text { atau } x \leq-1 \\
& \quad \text { Jadi Domain dari fungsi } f(x) \text { adalah } \\
& D=\{x \mid x \geq 3, \text { atau } x \leq-1\}
\end{aligned}
$$

Atau dengan menggunakan selang himpunan sebagai berikut :

$$
(-\infty,-1] \cup[3,+\infty)
$$

Dengan menggunakan garis bilangan sebagai berikut :

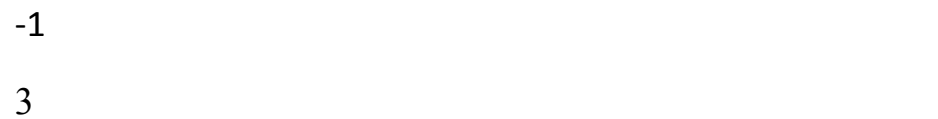

Gambar 2.9. Selang Contoh 2.5

\section{RANGE FUNGSI (DAERAH HASIL)}

Setalah kita mengetahui arti dari domain fungsi, lalu apa yang dimaksud range suatu fungsi? Range suatu fungsi merupakan nilai atau hasil yang diperoleh ketika nilai yang berada pada cakupan domain dimasukkan kedalam fungsi, atau biasa disebut sebagai daerah hasil fungsi. Kumpulan nilai y disebut sebagai range fungsi. Range suatu fungsi dinotasikan dengan $R_{f}$. 
Untuk memahami range suatu fungsi, Anda perlu memasukkan beberapa koordinat $x$ lainnya sehingga Anda memahami gambaran fungsi sebelum mulai mencari range. Karena fungsinya parabola dan koordinat $x^{2}$ positif, kurvanya menghadap ke atas. Misalkan masukkan beberapa nilai (domain) terhadap fungsi $f(x)=x^{2}$.

- $f(-2)=(-2)^{2}=4$. Koordinat pada grafik adalah $(-2,4)$

- $f(0)=(0)^{2}=0$. Koordinat lain pada grafik adalah $(0,0)$

- $f(2)=(2)^{2}=4$. Koordinat lain pada grafik adalah $(2,4)$

Sehingga yang dimaksud range disini adalah semua hasil ketika domain dimasukkan kedalam fungsi. Domain dari $f(x)=x^{2}$ adalah semua nilai $x \in R$, atau dengan notasi selang $(-\infty,+\infty)$. Dengan demikian Range dari fungsi $f(x)=x^{2}$,

- $f(x)=(-\infty)^{2}=+\infty$, tanda negatif dikuadratkan menjadi positif

- $f(x)=(+\infty)^{2}=+\infty$, tanda positif dikuadratkan tetap positif

- $f(x)=(0)^{2}=0$, mencari batas paling bawah range fungsi, yaitu titik 0

Sehingga dengan menggunakan selang, range fungsi $f(x)=x^{2}$ adalah $[0,+\infty)$.

\section{SOAL LATIHAN}

1. Diberikan fungsi $f(x)=x^{2}+3 x-4$, dapatkan :
a. $f(-2)$
b. $f(a-1)$ 

c. $f(0)$
d. $f(2 t)$
e. $f(-\sqrt{3})$

2. Diberikan fungsi $f(x)=\left\{\frac{1}{x}, x>44 x x \leq 4\right.$, dapatkan :
a. $f(-5)$
b. $f(3)$
c. $f(10)$
d. $f\left(t^{2}-1\right)$
e. $f(\pi)$

3. Dapatkan domain alami dari fungsi-fungsi yang diberikan :
a. $f(x)=\frac{1}{x-3}$
b. $f(s)=\frac{1}{2 s-4}$
c. $f(x)=\frac{1}{1-\sin \sin x}$
d. $g(x)=\sqrt{x^{2}-9}$
e. $g(x)=\sqrt{x^{2}-3 x+4}$
f. $\quad h(x)=\sqrt{\frac{x-2}{x+1}}$

4. Dapatkan domain dan range dari fungsi-fungsi yang diberikan :
a. $F(x)=x^{2}+5$
b. $F(s)=\frac{1}{2+\sqrt{x}}$
c. $H(x)=\frac{2}{x^{2}-4}$
d. $H(x)=\sqrt{\frac{x^{2}-9}{x-3}}$
e. $F(x)=4 \sin \sin 2 x$

\subsection{OPERASI-OPERASI PADA FUNGSI}


Seperti halnya bilangan yang dapat dijumlahkan, dikurangkan, dikalikan dan dibagi, fungsi-fungsi juga dapat dilakukan hal yang sama seperti halnya operasi pada bilangan. Fungsi dapat dijumlahkan, dikurangkan, dikalikan dan dibagi. Secara umum, fungsi dapat didefinisikan sebagai berikut :

Jika ada dua fungsi $f(x)$ dan $g(x)$, maka berlaku rumus-rumus yang didefinisikan oleh :

1. $(f+g)(x)=f(x)+g(x)$

2. $(f-g)(x)=f(x)-g(x)$

3. $(f \cdot g)(x)=f(x) \cdot g(x)$

4. $\left(\frac{f}{g}\right)(x)=\frac{f(x)}{g(x)}$

5. $f^{n}(x)=[f(x)]^{n}$

6. $(f \circ g)(x)=f(g(x))$

Fungsi-fungsi $f+g, f-g$ dan $f \cdot g$ didefinisikan sebagai irisan dari domain-domain masing-masing $f$ dan $g$. Sedangkan nomor 6 merupakan komposisi fungsi $f$ dan $g$.

\section{Contoh 2.6 :}

Misalkan $f(x)=2 x$ dan $g(x)=x^{2}+1$, tentukan :

a. $(f+g)(x)$

b. $(f \cdot g)(x)$

c. $\left(\frac{f}{g}\right)(x)$

d. $(f \circ g)(x)$

Beserta domain masing-masing $f(x)$ dan $g(x)$ !

Penyelesaian :

a. $(f+g)(x)=f(x)+g(x)=2 x+\left(x^{2}+1\right)=x^{2}+2 x+1$

b. $(f \cdot g)(x)=f(x) \cdot g(x)=(2 x) \cdot\left(x^{2}+1\right)=2 x^{3}+2 x$

c. $\left(\frac{f}{g}\right)(x)=\frac{f(x)}{g(x)}=\frac{2 x}{x^{2}+1}$ 
d. $(f \circ g)(x)=f(g(x))=f\left(x^{2}+1\right)=2\left(x^{2}+1\right)=2 x^{2}+2$ Dengan menggunakan selang, diketahui bahwa domain dari $f(x)=2 x$ adalah $(-\infty,+\infty)$, dan domain dari $g(x)=x^{2}+1$ adalah $[-\infty,+\infty)$.

\section{KLASIFIKASI FUNGSI}

Banyak sekali fungsi yang dapat dibuat, fungsi-fungsi yang paling sederhana adalah fungsi yang mempunyai domain sama, misalkan $f(1)=3, f(0)=3, f(-1)=3$ dan seterusnya. Fungsi sederhana dalam Kalkulus 1 dibagi kedalam beberapa, diantaranya adalah :

1. Polinomial atau suku banyak, antara lain Polinomial linier, polinomial Kuadratik, dan Polinomial Kubik. Polinomial derajat pertama, kedua, ketiga berturut-turut disebut linier, kuadratik, dan kubik.

a. Polinomial Linier

Polinomial Linier bentuknya adalah $a_{0}+a_{1} x$ dengan $a_{1} \neq 0$.

b. Polinomial Kuadratik

Polinonial Kuadratik mempunyai pangkat paling tinggi (derajat) dua pada fungsinya, rumus umumnya dalah $a_{0}+a_{1} x+a_{2} x^{2}$ dengan $a_{2} \neq 0$.

c. Polinomial Kubik

Polinomial kubik mempunyai derajat paling tinggi tiga, dengan rumus umum sebagai berikut $a_{0}+a_{1} x+a_{2} x^{2}+a_{3} x^{3}$ dengan $a_{3} \neq 0$.

2. Fungsi rasional 
Suatu fungsi dapat dinyatakan sebagai rasio dua polinomial, yaitu fungsi rasional. Secara umum, $f$ terdiri dari semua $x$ dan dapat dinyatakan sebagai berikut:

$$
f(x)=\frac{a_{0}+a_{1} x+a_{2} x^{2}+\cdots+a_{n} x^{n}}{b_{0}+b_{1} x+b_{2} x^{2}+\cdots+b_{n} x^{n}}
$$

3. Fungsi trigonometri

4. Fungsi eksponensial

5. Fungsi sepotong - sepotong

\section{SOAL LATIHAN}

1. Misalkan $f(x)=\frac{3}{2 x}$, tentukan :
a. $f\left(\frac{1}{x}\right)+\frac{1}{f(x)}$
b. $f\left(x^{2}\right)+f^{2}(x)$

2. Diketahui $f(x)=\frac{x}{x+1}, g(x)=\frac{1}{x^{2}}$, tentukan operasi fungsi berikut, dan dapatkan pula domainnya :
a. $(f+g)(x)$
b. $(f \cdot g)(x)$
c. $(f \circ g)(x)$

3. Diketahui $f(x)=\sqrt{x-4}$ dan $g(x)=\sqrt{x-5}$, dapatkan domain untuk masing-masing soal, dan tentukan operasinya :
a. $(f-g)(x)$
b. $\left(\frac{f}{g}\right)(x)$
c. $(g \circ f)(x)$

4. Misalkan $h(x)=2 x+10$. Dapatkan domain untuk masing-masing soal, dan tentukan operasinya :
a. $(h \circ h)(x)$
b. $h^{2}(x)$ 


\subsection{GRAFIK FUNGSI}

Jika diberikan fungsi $f$. Himpunan $\left\{(x, y): y=f(x), x \in D_{f}\right\}$ disebut grafik fungsi $f$. Ada beberapa macam fungsi sebagaimana telah dijelaskan pada sub-bab sebelumya, diantaranya yang sering kita jumpai adalah fungsi linier, fungsi kuadrat, fungsi persamaan kubik. Untuk mengetahui persamaan garis dari grafik suatu fungsi, yaitu

$$
\frac{y-y_{1}}{y_{2}-y_{1}}=\frac{x-x_{1}}{x_{2}-x_{1}}
$$

A. Fungsi linier

Fungsi Linier adalah fungsi yang mempunyai pangkat tertinggi pada fungsi adalah satu, grafiknya berupa garis lurus (bukan berkelok). Fungsi Linier bentuknya adalah $a_{0}+a_{1} x$ dengan $a_{1} \neq 0$. Contoh fungsi linier pada gambar A, B, C dan D berikut ini. Pada Gambar A merupakan fungsi linier $y=-2 x+6$ atu $y=-x+3$

A.

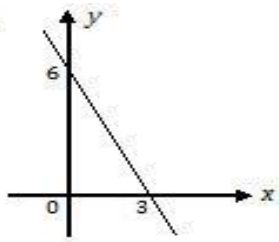

B.

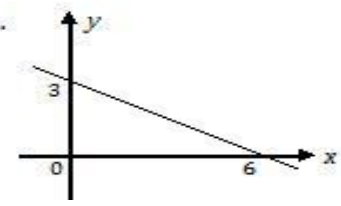

Gambar 2.10. Grafik Fungsi Linier c.

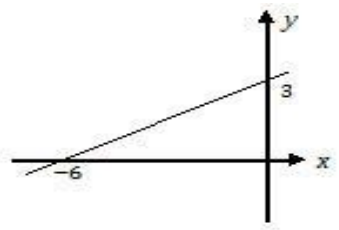

D.

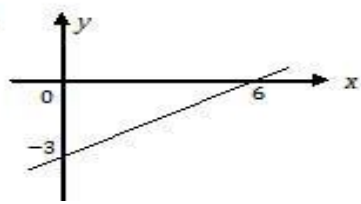

B. Fungsi Kuadrat 
Fungsi Kuadrat adalah fungsi yang mempunyai pangkat tertinggi pada suatu fungsi atau persamaan sebanyak dua (pasti mempunyai titik belok satu buah), rumus umumnya dalah $a_{0}+a_{1} x+a_{2} x^{2}$ dengan $a_{2} \neq 0$. Sebenarnya ada cara yang dapat digunakan untuk menentukan gambaran umum dari grafik sebuah persamaan kuadrat dengan cara melihat nilai determinannya. Nilai Determinan dari sebuah fungsi kuadrat adalah $D=b^{2}-4 a c$. Determinan dapat digunakan untuk menyelidiki berapa banyak akar yang dimiliki sebuah persamaan kuadrat. Selain itu, determinan dapat digunakan untuk menentukan jenis akar yang dimiliki suatu persamaan kuadrat.

Karakteristik grafik berdasarkan nilai determinan:

1. Jika $D>0$ maka persamaan kuadrat memiliki dua akar real berbeda (artinya, grafik akan memotong sumbu $x$ pada dua titik).

2. Jika $D=0$ maka persamaan kudrat memiliki dua akar real kembar (artinya, grafik akan memotong sumbu $\mathrm{x}$ pada satu titik).

3. Jika $D<0$ maka persamaan kuadrat memiliki akar yang imaginer/tidak real/akar negatif (artinya, grafik tidak memotong sumbu $x)$.

Nilai $a$ (koefisien dari $x^{2}$ ) dapat memberi gambaran grafik fungsi kuadrat tersebut terbuka ke atas atau ke bawah. Karakteristik grafik berdasarkan nilai $a$ :

1. Jika $a>0$ maka grafik akan terbuka ke atas.

2. Jika $a<0$ maka grafik akan terbuka ke bawah.

Gambaran umum Grafik fungsi kuadrat jika dilihat dari nilai $a$ dan $D$ : 


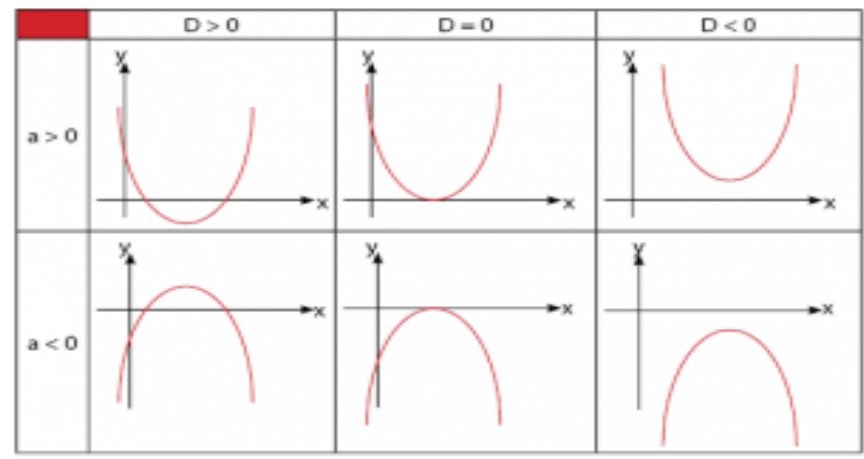

Gambar 2.11. Grafik Fungsi Kuadrat

C. Fungsi Kubik

Polinomial kubik mempunyai derajat paling tinggi tiga, dengan rumus umum sebagai berikut $a_{0}+a_{1} x+a_{2} x^{2}+a_{3} x^{3}$ dengan $a_{3} \neq 0$.

\section{Contoh 2.7 :}

Buatlah sketsa grafik fungsi $f(x)=x^{3}$ dan fungsi $f(x)=(x-1)^{3}$ !

\section{Penyelesaian :}

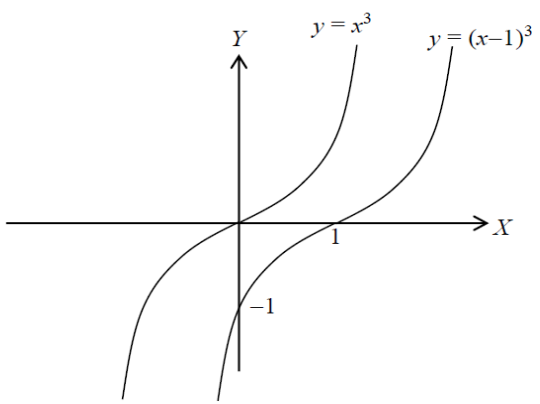

Gambar 2.12.Grafik Fungsi Kubik 
D. Fungsi Rasional

Suatu fungsi dapat dinyatakan sebagai rasio dua polinomial, yaitu fungsi rasional. Secara umum, $f$ terdiri dari semua $x$ dan dapat dinyatakan sebagai berikut :

$$
f(x)=\frac{a_{0}+a_{1} x+a_{2} x^{2}+\cdots+a_{n} x^{n}}{b_{0}+b_{1} x+b_{2} x^{2}+\cdots+b_{n} x^{n}}
$$

\section{Contoh 2.8 :}

Buatlah sketsa grafik fungsi berikut dalam satu koordinat cartesius :
a. $f(x)=\frac{x}{x-1}$
b. $y=\frac{1}{x}$
c. $y=1$
d. $x=1$

\section{Penyelesaian :}

Untuk proses belajar, menggambar grafik bisa dimulai dengan plotting titik-titik kedalam bentuk tabel seperti dalam subbab sebelumnya.

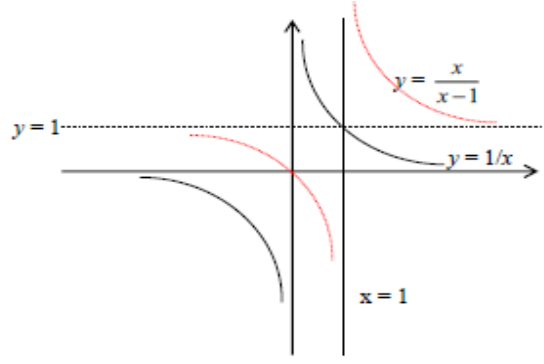

Gambar 2.13. Grafik Fungsi Rasional

\section{E. Fungsi Trigonometri}

Fungsi Trigonometri merupakan fungsi dari sebuah sudut yang digunakan untuk menghubungkan antara sudut-sudut dalam segitiga dengan sisi-sisi segitiga tersebut. Apabila $r$ menyatakan jarak titik $P$ ke $O$ dan $\theta$ menyetakan besar sudut antara $O P$ dengan sumbu $x$ 
(arah berlawanan dengan jarum jam), maka berturut-turut didefinisikan pada Tabel sebagai berikut :

Tabel 6. Bentuk Trigonometri dalam Koordinta Cartesius

\begin{tabular}{|c|c|}
\hline Sin & $\operatorname{Cos}$ \\
\hline $\sin \sin \theta=y / r$ & $\cos \cos \theta=x / r$ \\
\hline $\sin \sin \theta=y / x$ & $\cos \cos \theta=x / y$ \\
\hline $\sin \sin \theta=r / x$ & $\cos \cos \theta=r / y$ \\
\hline
\end{tabular}

Ditinja titik sebarang $p(x, y)$ pada bidang koordinat seperti terlihat dalam gambar berikut ini.

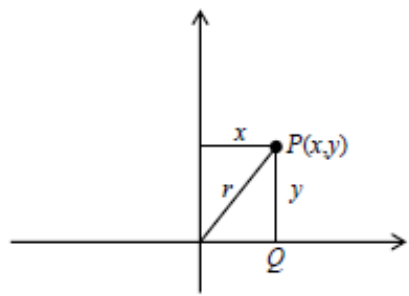

Gambar 2.14. Grafik Fungsi Trigonometri Dalam Koordinat $x$ dan $y$ Berikut merupakan contoh beberapa grafik fungsi trigonometri fungsi $y=\sin \sin x$ dan $y=\cos \cos x$.

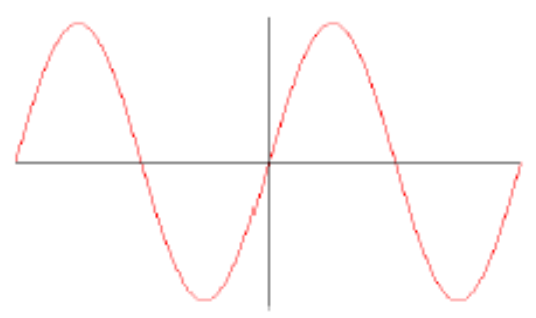

Gambar 2.15. Grafik Fungsi $y=\sin \sin x$

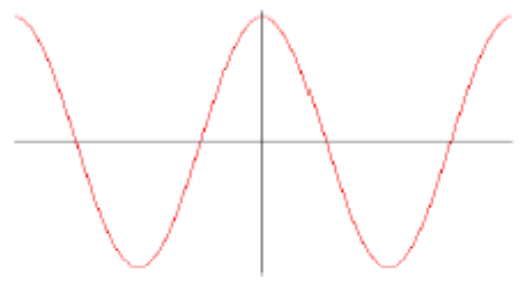


Gambar 2.16. Grafik Fungsi $y=\cos \cos x$

\subsection{PENGANTAR LIMIT}

Perkembangan Kalkulus seringkali diilhami oleh dua permasalahan goemetri yaitu mencari luas daerah bidang, dan garis singgung (tangent) pada kurva. Pada bagian ini akan ditunjukkan bahwa masalah-masalah tersebut berkaitan erat dengan konsep dasar kalkulus yang dikenal dengan "Ilimit".

\section{MASALAH LUAS DAN GARIS SINGGUNG}

Kalkulus mengarah pada dua permasalahan dasar yaitu mengenai masalah garis singgung dan masalah luas.

Masalah Garis Singgung. Diberikan fungsi $f$ dan titik $P\left(x_{0}, y_{0}\right)$ pada grafiknya. Dapatkan persamaan garis singgung grafik $P$.

Masalah Luas. Diberikan fungsi $f$, dapatkan luas antara grafik $f$ dan suatu selang $[a, b]$ pada sumbu- $x$.

\section{MASALAH GARIS SINGGUNG DAN LIMIT}

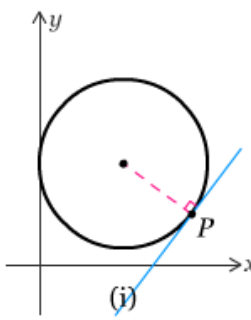

(i)

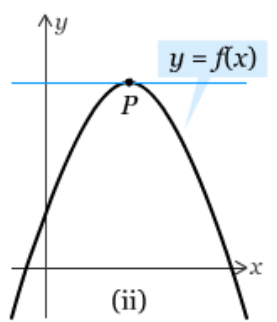

(ii)
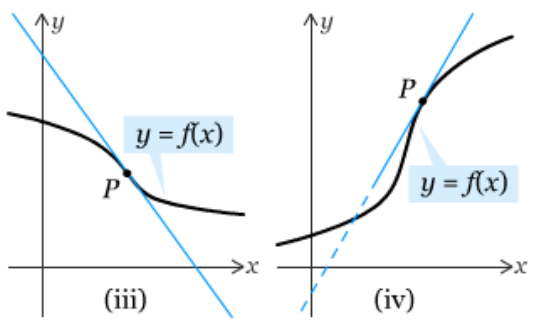

Gambar 2.17. Masalah Garis Singgung

Untuk mendefinisikan konsep garis singgung sehingga berlaku untuk kurva selain lingkaran, harus dipandang dengan cara yang lain. 
Perhatikan kurva pada bidang-xy, jika $Q$ adalah titik pada kurva yang berbeda dengan $\mathrm{P}$, maka garis yang melalui $\mathrm{P}$ dan $\mathrm{Q}$ disebut garis potong kurva. Jika titik $Q$ digerakkan sepanjang kurva menuju titik $P$, garis potong akan memutar menuju ke posisi "limit". Garis dalam posisi limit ini dipandang sebagai garis singgung.

\section{MASALAH LUAS SEBAGAI SUATU LIMIT}

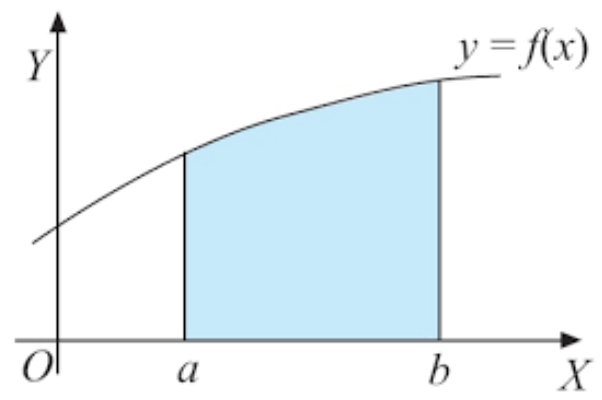

Gambar 2.18. Masalah Luas Sebagai Suatu Limit

Luas area pada Gambar 2.18 diatas, dapat didekati menggunakan konsep "limit". Apabila luasan dibagi menjadi beberapa bagian bidang/sekat/pias kemudian pada setiap bidang dihitung menggunakan pendekatan rumus geometri trapesium, atau segiempat, kemudian hasil tiap bidang dijumlahkan sampai luasan yang diperoleh mendekati hasil luasan yang sebenarnya. Akan tetapi, agar memperoleh error yang semakin kecil dan semakin mendekati hasil yang sebenarnya, bidang/sekat/pias dibagi menjadi berhingga semakin kecil, kemudian dengan cara yang sama yaitu menjumlahkan setiap luas bidang. Penghampiran yang dilakukan ini akan "mendekati" luas sebenarnya dibawah kurva tersebut, sehingga hal ini merupakan suatu "nilai limit".

\section{LIMIT}


Suatu fungsi memetakan keluaran $f(x)$ untuk setiap masukan $x$. Fungsi tersebut memiliki limit $L$ pada titik masukan $p$ bila $f(x)$ "dekat" pada $L$ ketika $x$ juga mendekat menuju $p$. Lebih jauh lagi, bila $f$ diterapkan pada tiap masukan yang cukup dekat pada $p$, hasilnya adalah keluaran yang (secara sembarang) dekat dengan $L$. Bila masukan yang dekat pada $p$ ternyata dipetakan pada keluaran yang sangat berbeda, fungsi $f$ dikatakan tidak memiliki limit.

Limit. Limit suatu fungsi merupakan salah satu konsep mendasar dalam kalkulus dan analisis, tentang kelakuan suatu fungsi mendekati titik masukan tertentu.

$$
f(x)=+\infty
$$

Atau

$$
f(x)=-\infty
$$

Dapat dilihat pada Gambar 2.17 berikut ini :

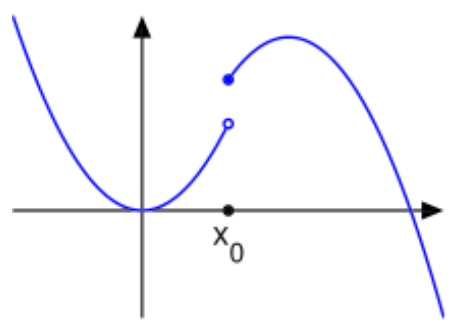

Gambar 2.19. Gambar grafik limit fungsi

Limit saat: $\mathrm{x} \rightarrow \mathrm{x} 0+\neq \mathrm{x} \rightarrow \mathrm{x} 0-$. Maka, limit $\mathrm{x} \rightarrow \mathrm{x} 0$ tidak ada.

( $214 \times 153$ piksel, ukuran berkas: $6 \mathrm{~KB}$, tipe MIME: image/png) 


\subsection{TEKNIK PERHITUNGAN LIMIT}

Pada bagian sebelumnya, pembahasan limit ditekankan pada interpretasi limit melalui grafik. Pada bagian ini akan dibahas mengenai teknik-teknik untuk mendapatkan limit secara langsung dari rumus suatu fungsi. Berikut ini merupakan beberapa limit dasar yang akan membentuk dasar untuk mendapatkan beberapa limit yang lebih kompleks. Berikut pada Tabel 7. Memperlihatkan fungsi limit pada sisi kiri dan contohnya pada tabel sebelah kanan.

Tabel 7. Limit Dasar

\begin{tabular}{|c|c|}
\hline Limit & Contoh \\
\hline 1. $k=k$ & $2=2, \quad 2=2$ \\
\hline 2. $\quad k=k$ & $2=2$ \\
\hline 3. $k=k$ & $2=2$ \\
\hline 4. $x=a$ & $x=3$ \\
\hline 5. $x=+\infty$ & $x=+\infty$ \\
\hline 6. $x=-\infty$ & $x=-\infty$ \\
\hline
\end{tabular}

\section{Sifat-sifat Limit}

1. $c=c$ 
2. $x^{n}=a^{n}$

3. $c f(x)=c f(x)$

4. $(f(x) \pm g(x))=f(x) \pm g(x)$

5. $(f(x) \times g(x))=f(x) \times g(x)$

6. $\frac{f(x)}{g(x)}=\frac{f(x)}{g(x)}$

7. $f(x)^{n}=(f(x))^{n}$

8. $\sqrt[n]{f(x)}=\sqrt[n]{f(x)}$

\section{LIMIT DARI POLINOMIAL UNTUK $x \rightarrow a$}

Untuk sebarang polinomial

$$
p(x)=c_{0}+c_{1} x+\ldots+c_{n} x^{n}
$$

Dan sebarang bilangan real $a$

$$
p(x)=c_{0}+c_{1} x+\ldots+c_{n} x^{n}=p(a)
$$

\section{Contoh 2.9:}

Dapatkan $x^{3}-3 x^{2}+3 x-1$ dengan langkah-langkah yang jelas!

Penyelesaian :

$x^{3}-3 x^{2}+3 x-1=x^{3}-\lim _{x \rightarrow 3} 3 x^{2}+\lim _{x \rightarrow 3} 3 x-\lim _{x \rightarrow 3} 1$

$=x^{3}-3 \lim _{x \rightarrow 3} x^{2}+3 \lim _{x \rightarrow 3} x-\lim _{x \rightarrow 3} 1$

$=(3)^{3}-3\left(3^{2}\right)+3(3)-1$

$=27-27+9-1$ 
Atau dengan menggunakan limit polinomial, dapat dituliskan sebagai $x^{3}-3 x^{2}+3 x-1=(3)^{3}-3\left(3^{2}\right)+3(3)-1=8$

\section{LIMIT YANG MEMUAT $1 / x$}

Limit suatu fungsi $f(x)=1 / x$ yang didekati nilai 0 dari arah kiri atau arah kanan, dan yang didekati nilai $+\infty$ maupun $-\infty$ adalah sebagai berikut :

$$
\frac{1}{x}=+\infty, \quad \frac{1}{x}=-\infty, \quad \frac{1}{x}=0, \quad \frac{1}{x}=0
$$

Untuk setiap bilangan real a pada grafik fungsi $1 /(x-a)$ merupakan pergeseran dari grafik $1 / x$. Sehingga limit-limit berikut dapat disimpulkan dengan menganalisis secara mudah hasil dari limit sebagai berikut :

$$
\begin{aligned}
\frac{1}{x-a} & =+\infty, & \frac{1}{x-a} & =-\infty, \\
\frac{1}{x-a} & =0, & \frac{1}{x-a} & =0
\end{aligned}
$$

LIMIT DARI POLINOMIAL UNTUK $x \rightarrow+\infty$ atau $x \rightarrow-\infty$

Grafik polinomial berbentuk $x^{n}$, dengan $n$ adalah bilangan asli genap dan ganjil untuk $x \rightarrow+\infty$ dan $x \rightarrow-\infty$, didapatkan bentuk umum sebagai berikut :

$$
x^{n}=+\infty, \quad n=1,2,3, \ldots
$$




$$
x^{n}=\{+\infty n=2,4,6, \ldots-\infty n=1,3,5, \ldots
$$

\section{Contoh 2.10 :}

$$
\begin{aligned}
2 x^{7} & =+\infty & 2 x^{7} & =-\infty \\
2 x^{4} & =-\infty & -2 x^{7} & =+\infty
\end{aligned}
$$

Demikian pula untuk polinomial berbentuk $f(x)=c_{0}+c_{1} x+\ldots+c_{n} x^{n}$, apabila didekati dengan limit maka derajat tertinggi yang mempunyai peran dalam penghitungan.

$$
\begin{aligned}
& \left(c_{0}+c_{1} x+\ldots+c_{n} x^{n}\right)=c_{n} x^{n} \\
& \left(c_{0}+c_{1} x+\ldots+c_{n} x^{n}\right)=c_{n} x^{n}
\end{aligned}
$$

\section{Contoh 2.11 :}

$$
\begin{aligned}
& 5 x^{9}-3 x^{7}+2 x+7=\lim _{x \rightarrow+\infty} 5 x^{9}=+\infty \\
& -5 x^{10}+2 x^{8}+3 x+6=\lim _{x \rightarrow-\infty}-5 x^{10}=-\infty
\end{aligned}
$$

\section{LIMIT DARI FUNGSI RASIONAL UNTUK $x \rightarrow+\infty$ atau $x \rightarrow-\infty$}

Fungsi Rasonal merupakan pembagian dari fungsi polinomial. Limit dari pembagian sama dengan masing-masing pembilang dan penyebut dilimitkan. Konsep ini sama dengan konsep limit pada limit $1 / x$ dengan pendekatan $+\infty$ dan $-\infty$. 


\section{Contoh 2.12 :}

Dapatkan $\frac{2 x+5}{3 x-6}$

\section{Penyelesaian :}

Bagilah pembilang dan penyebut dengan $x$ pangkat tertinggi penyebut, yaitu pada soal pangkat tertingginya yaitu 1 , sehingga dibagi dengan $x$.

$\frac{2 x+5}{3 x-6}=\lim _{x \rightarrow+\infty} \frac{2+5 / x}{3-6 / x}=\frac{\lim _{x \rightarrow+\infty} 2+5 / x}{\lim _{x \rightarrow+\infty} 3-6 / x}=\frac{\lim _{x \rightarrow+\infty} 2+\lim _{x \rightarrow+\infty} 5 / x}{\lim _{x \rightarrow+\infty} 3-\lim _{x \rightarrow+\infty} 6 / x}=\frac{2+5 \lim _{x \rightarrow+\infty} 1 / x}{3-6 \lim _{x \rightarrow+\infty} 1 / x}=\frac{2+(5 .}{3-(6 .}$

Metode cepat mendapatkan limit fungsi rasional untuk $x \rightarrow+\infty$ atau $x \rightarrow-\infty$ adalah dengan cara menghilangkan semua suku polinomial kecuali suku dengan pangkat tertinggi sesuai dengan rumus limit polinomial untuk $x \rightarrow+\infty$ atau $x \rightarrow-\infty$.

$$
\begin{aligned}
& \lim _{x \rightarrow+\infty} \frac{c_{0}+c_{1} x+\ldots+c_{n} x^{n}}{d_{0}+d_{1} x+\ldots+d_{m} x^{m}}=\lim _{x \rightarrow+\infty} \frac{c_{n} x^{n}}{d_{m} x^{m}} \\
& \lim _{x \rightarrow-\infty} \frac{c_{0}+c_{1} x+\ldots+c_{n} x^{n}}{d_{0}+d_{1} x+\ldots+d_{m} x^{m}}=\lim _{x \rightarrow-\infty} \frac{c_{n} x^{n}}{d_{m} x^{m}}
\end{aligned}
$$

\section{Contoh 2.13 :}

Gunakan cara cepat untuk mendapatkan :
a. $\lim _{x \rightarrow+\infty} \frac{2 x+6}{6 x+2}$
b. $\lim _{x \rightarrow-\infty} \frac{2 x^{2}+2}{3 x^{3}-5}$
c. $\lim _{x \rightarrow+\infty} \frac{2-5 x^{5}}{x^{2}+1}$ 


\section{Penyelesaian :}

Penyelesaian (a).

$$
\lim _{x \rightarrow+\infty} \frac{2 x+6}{6 x+2}=\lim _{x \rightarrow+\infty} \frac{2 x}{6 x}=\lim _{x \rightarrow+\infty} \frac{2}{6}=\frac{2}{6}=\frac{1}{3}
$$

Penyelesaian (b).

$$
\lim _{x \rightarrow-\infty} \frac{2 x^{2}+2}{3 x^{3}-5}=\lim _{x \rightarrow-\infty} \frac{2 x^{2}}{3 x^{3}}=\lim _{x \rightarrow-\infty} \frac{2}{3 x}=0
$$

Penyelesaian (c).

$$
\lim _{x \rightarrow+\infty} \frac{2-5 x^{5}}{x^{2}+1}=\lim _{x \rightarrow+\infty} \frac{-5 x^{5}}{x^{2}}=\lim _{x \rightarrow+\infty}-5 x^{3}=-\infty
$$

Note : Rumus ini hanya berlaku untuk $x \rightarrow+\infty$ atau $x \rightarrow-\infty$, akan tetapi tidak berlaku untuk $x \rightarrow a$.

\section{LIMIT YANG MEMUAT AKAR}

Sama halnya dengan limit fungsi rasional, limit yang memuat akar juga mempunyai pengerjaan yang sama yaitu limit diletakkan setelah fungsi akar.

\section{Contoh 2.14 :}

Gunakan cara cepat untuk mendapatkan nilai limit berikut :

a. $\lim _{x \rightarrow+\infty} \sqrt{\frac{2 x+6}{6 x-2}}$ 

b. $\lim _{x \rightarrow+\infty} \frac{\sqrt{x^{2}-4}}{2 x-3}$
C. $\lim _{x \rightarrow-\infty} \frac{3 x-6}{\sqrt{x^{2}-4}}$

\section{Penyelesaian :}

Penyelesaian (a).

$$
\lim _{x \rightarrow+\infty} \sqrt{\frac{2 x+6}{6 x-2}}=\sqrt{\lim _{x \rightarrow+\infty} \frac{2 x+6}{6 x-2}}=\sqrt{\lim _{x \rightarrow+\infty} \frac{2 x}{6 x}}=\sqrt{\lim _{x \rightarrow+\infty} \frac{2}{6}}=\frac{1}{3}
$$

Penyelesaian (b).

$$
\begin{gathered}
\lim _{x \rightarrow+\infty} \frac{\sqrt{x^{2}-4}}{2 x-3}=\lim _{x \rightarrow+\infty} \frac{\sqrt{x^{2}-4} /|x|}{2 x-3 /|x|}=\lim _{x \rightarrow+\infty} \frac{\sqrt{x^{2}-4} / \sqrt{x^{2}}}{2 x-3 / x} \\
=\lim _{x \rightarrow+\infty} \frac{\sqrt{x^{2}-4 / x^{2}}}{(2 x-3) / x}=\lim _{x \rightarrow+\infty} \frac{\sqrt{1-4 / x^{2}}}{(2 x-3) / x}=\frac{\lim _{x \rightarrow+\infty} \sqrt{1-4 / x^{2}}}{\lim _{x \rightarrow+\infty}(2 x-3) / x} \\
=\frac{\sqrt{\lim _{x \rightarrow+\infty} 1-4 / x^{2}}}{\lim _{x \rightarrow+\infty}(2 x-3) / x}=\frac{\sqrt{\lim _{x \rightarrow+\infty} 1-\lim _{x \rightarrow+\infty} 4 / x^{2}}}{\lim _{x \rightarrow+\infty} 2-\lim _{x \rightarrow+\infty} 3 / x}=\frac{\sqrt{1-(4.0)}}{2-(3.0)}=\frac{\sqrt{1}}{2}=\frac{1}{2}
\end{gathered}
$$

Penyelesaian (c).

Untuk $x \rightarrow-\infty$, nilai dari $x$ selalu negatif $(-x)$, sehingga dapat mengganti $|x|$ dengan $-x$ apabila diperlukan.

$$
\lim _{x \rightarrow-\infty} \frac{3 x-6}{\sqrt{x^{2}-4}}=\frac{\lim _{x \rightarrow-\infty}(3 x-6) /|x|}{\lim _{x \rightarrow-\infty} \sqrt{x^{2}-4} /|x|}=\frac{\lim _{x \rightarrow-\infty}(3 x-6) /(-x)}{\lim _{x \rightarrow-\infty} \sqrt{x^{2}-4} / \sqrt{x^{2}}}=\frac{\lim _{x \rightarrow-\infty} \frac{6}{x}-3}{\lim _{x \rightarrow-\infty} \sqrt{1-4 / x^{2}}}=\frac{\lim _{x \rightarrow-\infty} \frac{6}{x}-}{\sqrt{\lim _{x \rightarrow-\infty} 1-}}
$$

\section{SOAL LATIHAN}

Dapatkan limit-limit untuk soal no 1-5 berikut : 
1. (a) -10
(b) 0
(c) $\pi$

(d) $-5 y$

(e) $-12 a$

(f) $5 x^{2}$

2. (a) $\sqrt{x^{3}-3 x-1}$

(b) $\left(-x^{5}+2 x^{3}-x+3\right)$

(c) $\frac{x^{2}-2 x}{x+1}$

(d) $\frac{(y-1)(y-2)}{(y+1)}$

3. (a) $\frac{1}{x-12}$

(b) $\frac{3}{y+4}$

(c) $\frac{5 x^{2}+7}{3 x^{2}-x}$

(d) $\frac{x-2}{3 x^{2}-2 x+1}$

4. (a) $\frac{\sqrt{5 x^{2}-2}}{x+3}$

(b) $\frac{2-y}{\sqrt{7+6 y^{2}}}$

(c) $\sqrt[3]{\frac{3 s^{7}-4 s^{5}}{2 s^{7}+1}}$

(d) $\frac{\sqrt{3 x^{4}+x}}{x^{2}-8}$

5. (a) $\frac{y+6}{y^{2}-3 y}$

(b) $\frac{y+6}{y^{2}-3 y}$

\subsection{LIMIT SEBAGAI SUATU PENDEKATAN}

Limit pada dasarnya merupakan suatu pendekatan terhadap fungsi pada nilai tertentu. Dengan mengintepretasikan suatu limit, misalkan $f(x)$ didefinisikan untuk semua $x$ pada suatu selang terbuka yang memuat bilangan $a$, kecuali mungkin $f(x)$ tidak terdefinisi di $x=a$, dapat ditulis sebagai berikut :

$$
f(x)=L
$$

Yaitu nilai-nilai dari $f(x)$ mendekati $L$. Untuk $x$ mendekati $a$ dari salah satu sisi, yaitu bisa dari kiri $a$ atau dari kanan $a$, atau biasa 
disebut dengan limit kiri dan limit kanan (yang artinya didekati dari arah kiri, dan limit didekati dari arah kanan).

Jika diberikan sebarang bilangan $\varepsilon>0$, maka dapat ditemukan suatu interval terbuka $\left(x_{0}, x_{1}\right)$ yang memuat titik a sedemikian hingga $f(x)$ memenuhi

$$
L-\varepsilon<f(x)<L+\varepsilon
$$

Untuk setiap $x$ dalam suatu selang $\left(x_{0}, x_{1}\right)$, kecuali mungkin $x=a$.

\section{KEBERADAAN LIMIT}

Secara umum tidak ada jaminan bahwa setiap fungsi yang didekati menggunakan limit mempunyai nilai limit misal untuk $x \rightarrow x_{0}^{+}, x \rightarrow x_{0}^{-}$, atau $x \rightarrow x_{0}$. Jika tidak mempunyai limit, maka dikatakan limit tersebut tidak ada. Dua penyebab umum limit suatu fungsi tidak ada yaitu :

a. Osilasi

b. Naik dan turun tak terbatas 


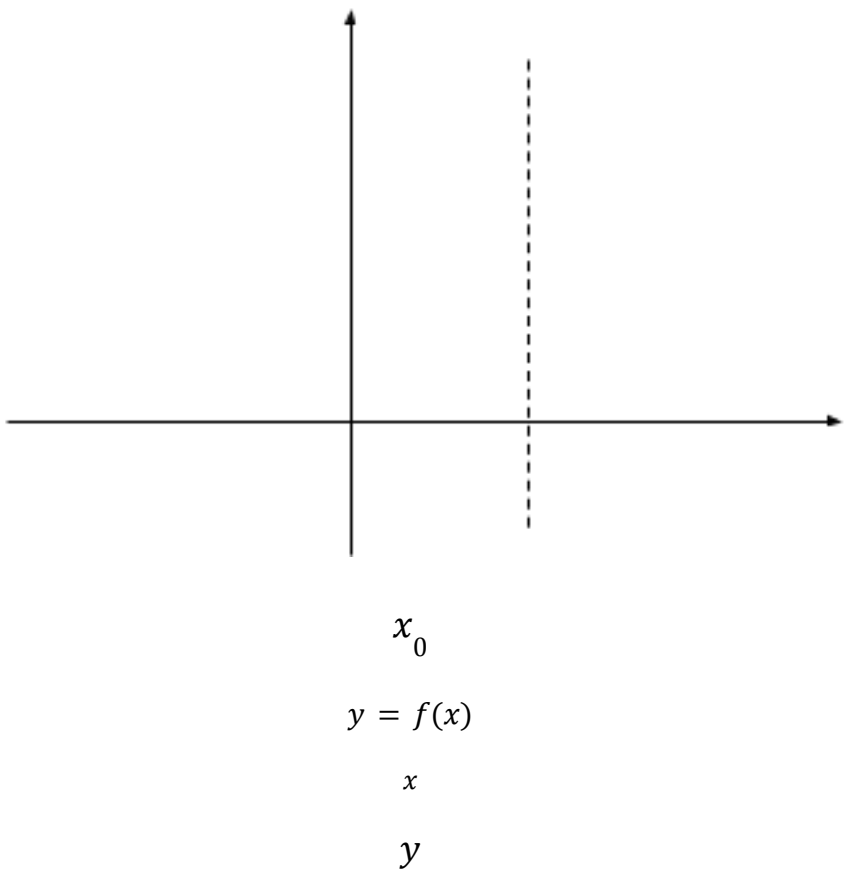

Gambar 2.20. Eksistensi Limit

Untuk menyatakan limit-limit pada gambar diatas dapat ditulis :

$$
f(x)=+\infty \operatorname{dan} f(x)=+\infty
$$

Dua ekspresi limit kiri dan limit kanan diatas biasanya dinyatakan dalam bentuk limit dua sisi dengan menuliskan

$$
f(x)=+\infty
$$

\section{Contoh 2.15 :}

Pandang $f$ suatu fungsi yang grafiknya tampak pada Gambar 2.21, dari Gambar tersebut ddidapatkan 


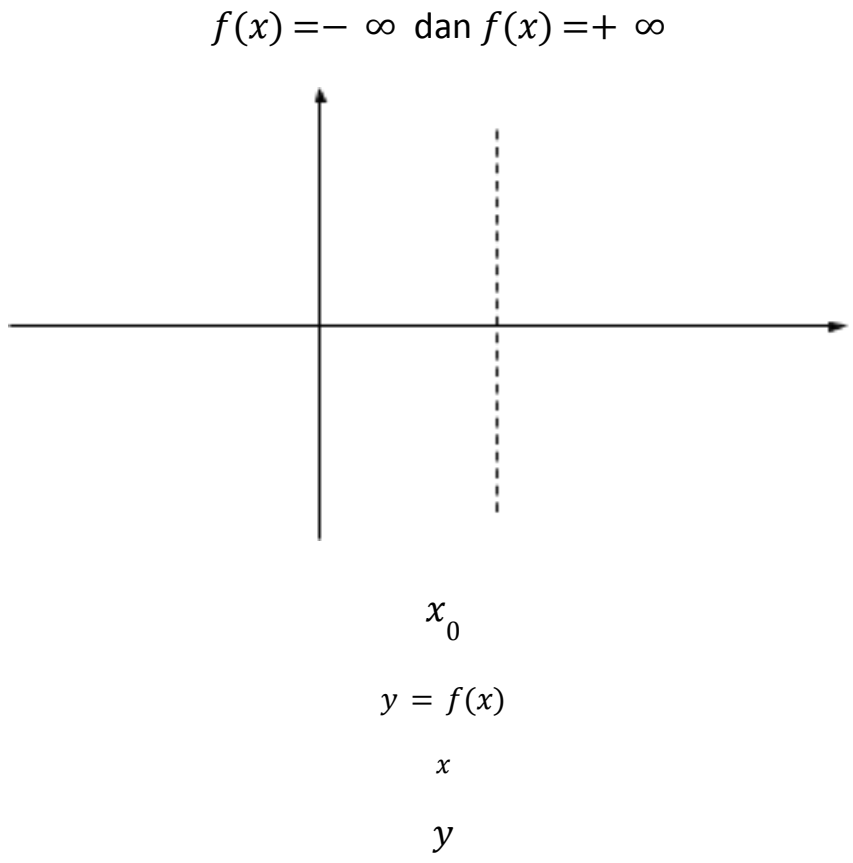

Gambar 2.21. Limit fungsi Tidak ada

Akan tetapi, dua ekspresi ini mempunyai dua tanda berlainan, tidak ada notasi khusus untuk menggabungkan keduanya dalam bentuk dua sisi.

$$
f(x)=f(x)=L
$$

Jika salah satu limit tidak ada, atu jika limit-limit satu sisikeduanya ada tetapi nilainya berbeda, maka disimpulkan bahwa limit dua sisi tidak ada, dan apabila ditulis

$$
f(x) \text { tidak ada }
$$

\section{Contoh 2.16 :}


Dimisalkan $f$ adalah fungsi dengan grafik seperti yang ditunjukkan pada Gambar 2.22. untuk $x \rightarrow+\infty$ grafik $f(x)$ mendekati garis $y=1$ sehingga nilai $f(x)$ mendekati 1 . Hal ini dinyatakan dengan

$$
f(x)=1
$$

Untuk $x \rightarrow-\infty$ grafik $f$ cenderung menuju $y=-1$, sehingga nilai $f(x)$ mendekati nilai -1 dan dapat dituliskan

$$
f(x)=-1
$$

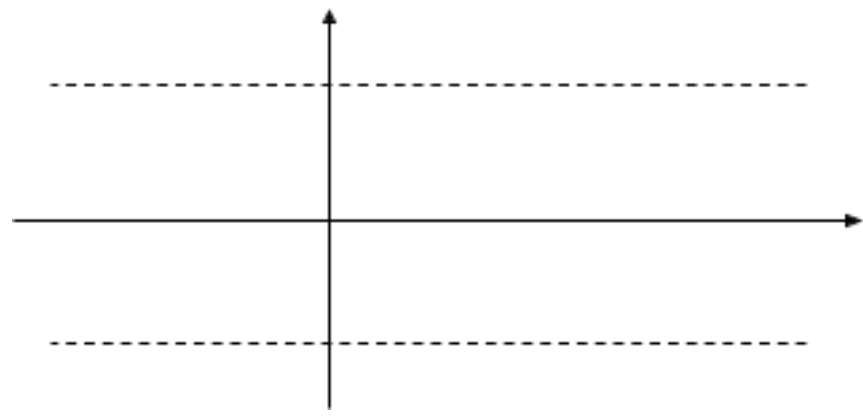

$$
y=f(x)
$$

$x$

$y$

$-1$

1

Gambar 2.22. Limit $x \rightarrow+\infty$ dan $x \rightarrow-\infty$

\subsection{KONTINUITAS}

Kontinuitas sering banyak dikaitkan dengan sebuah grafik suatu fungsi. Grafik $f$ dikatakan kontinu di suatu selang apabila secara harafiah grafik tersebut tidak terpotong-potong atau dengan kata lain grafik $f$ tersebut berupa garis mulus yang tidak terpisahkan satu dengan yang lain oleh perpotongan titik. Sebaliknya dikatakan $f$ 
diskontinu apabila garis terpotong oleh suatu titik sehingga garis mejadi garis yang tidak mulus lagi, dengan kata lain garis $f$ terputus dibagian tertentu menjadi beberap bagian dan tidak bisa tersambung lagi mejadi suatu fungsi $f$ yang mulus. Berdasarkan uraian ini, diskontinuitas terjadi pada kondisi-kondisi berikut ini yang akan digambarkan pada suatu grafik fungsi $f(x)$.

suatu fungsi $f$ dikatakan kontinu di titik $p$ jika syarat-syarat berikut terpenuhi :

a. $f(p)$ terdefinisi

b. $f(x)$ ada

c. $f(x)=f(p)$

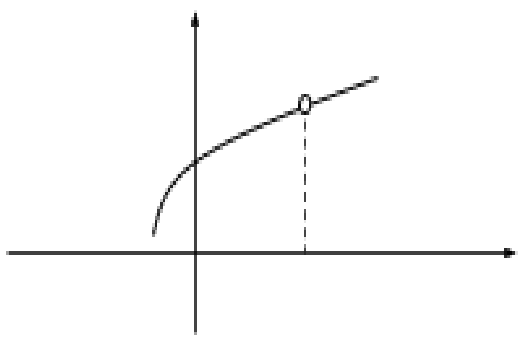

$$
\begin{gathered}
p \\
y=f(x) \\
x \\
y
\end{gathered}
$$

(a) 


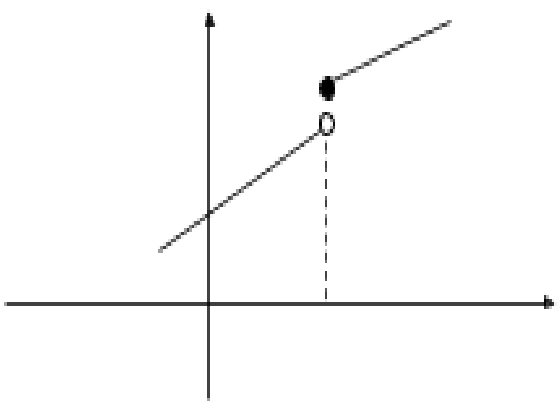

$$
\begin{gathered}
p \\
y=f(x) \\
x \\
y
\end{gathered}
$$

(b)

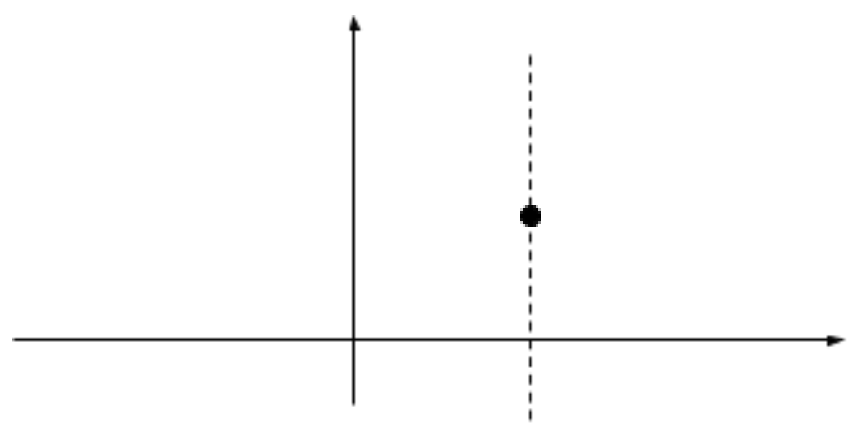

$$
\begin{gathered}
p \\
y=f(x) \\
x \\
y \\
\text { (c) }
\end{gathered}
$$


Gambar 2.23. (a) fungsi $f$ tidak terdefinisi di titik $p$, (b) dan (c) fungsi $f$ terdefinisi di $p$ tetapi $f(x)$ tidak ada

\section{Contoh 2.17 :}

Diberikan fungsi

$$
f(x)=\frac{x^{2}-9}{x-3} \text { dan } g(x)=\left\{\frac{x^{2}-9}{x-3} \quad x \neq 3 \quad 4 \quad x=3\right.
$$

\section{Penyelesaian :}

Kedua fungsi $f$ dan $g$ diskontinu di $x=3$, untuk fungsi $f$ disebabkan $f(3)$ tidak terdefinisi, untuk fungsi $g$ disebabkan $g(3)=4$, dan

$$
g(x)=\frac{x^{2}-9}{x-3}=(x+3)=6
$$

Sehingga

$$
g(x) \neq g(3)
$$

Yang dapat digambarkan dalam grafik berikut :
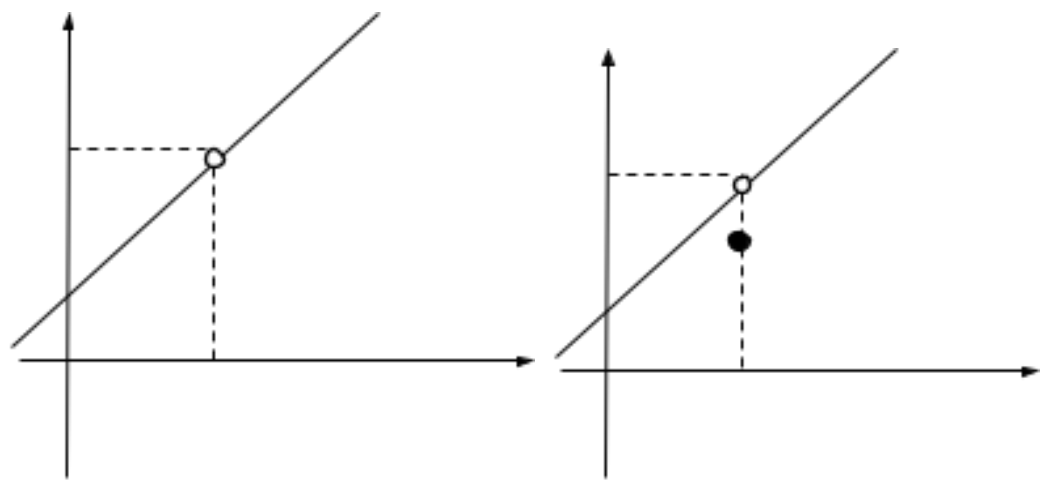

$$
y=f(x)
$$




$x$
$y$
6
3
$y=f(x)$
$x$
$y$
6
4

(a)

(b)

Gambar 2.24. Grafik Fungsi $f(x)=\frac{x^{2}-9}{x-3}$

\section{KONTINUITAS DARI KANAN DAN KIRI}

Definisi 2.7.1. Suatu fungsi $f$ dikatakan kontinu dari sebelah kiri titik c jika syarat-syarat pada kolom kiri berikut dipenuhi, dan dikatakan kontinu dari sebelah kanan titik c jika syarat-syarat pada kolom kanan berikut dipenuhi.

1. $f(c)$ terdefinisi

1'. $f(c)$ terdefinisi

2. $f(x) a d a$

2'. $f(x)$ ada

3. $f(x)=f(c)$

3'. $f(x)=f(c)$

Definisi 2.7.2. Suatu fungsi $f$ dikatakan kontinu pada suatu selang tertutup $[\mathbf{a}, \mathbf{b}]$ jika syarat-syarat berikut ini dipenuhi :

1. $f$ kontinu di $(a, b)$

2. $f$ kontinu dari kanan di $a$ 
3. $f$ kontinu dari kiri di $b$

Contoh 2.18 : Tunjukkan bahwa $f(x)=\sqrt{4-x^{2}}$ kontinu pada selang tertutup $[-2,2]$.

\section{Penyelesaian :}

Berdasarkan definisi 2.7.2. untuk nilai $c$ didalam selang $(-2,2)$, diperoleh

$$
f(x)=\sqrt{4-x^{2}}=\sqrt{\lim \left(x_{x \rightarrow c} 4-x^{2}\right)}=\sqrt{4-c^{2}}=f(c)
$$

Sehingga $f$ kontinu pada $(-2,2)$, dan juga

$$
\begin{aligned}
& f(x)=\lim _{x \rightarrow 2^{-}} \sqrt{4-x^{2}}=\sqrt{\lim _{x \rightarrow 2^{-}}\left(4-x^{2}\right)}=0=f(2) \\
& f(x)=\lim _{x \rightarrow 2^{+}} \sqrt{4-x^{2}}=\sqrt{\lim _{x \rightarrow 2^{+}}\left(4-x^{2}\right)}=0=f(-2)
\end{aligned}
$$

Sehingga $f$ kontinu pada $[-2,2]$

\section{SOAL LATIHAN}

Untuk soal a-u, dapatkan limit-limit dari fungsi yang diberikan!
a. 1000
b. $\sqrt{8}$
c. $\pi$
d. $3 x$
e. $3 x$
f. $(-3 y)$
g. $\sqrt{y^{2}-3 y-5}$
h. $\left(x^{4}+3 x^{2}-1\right)$
i. $\frac{x^{2}-2 x}{x^{2}-4}$
j. $\frac{1}{x-100}$
k. $\frac{3 x+1}{2 x-7}$
I. $\frac{\sqrt{5 x^{2}-2}}{x+2}$ 

m. $\frac{2-s}{\sqrt{5+2 s^{2}}}$
n. $\frac{y}{y-2}$
o. $\frac{y}{y-2}$
p. $\frac{x}{x^{2}-4}$
q. $\frac{x}{x^{2}-4}$
r. $\frac{x}{x^{2}-4}$
S. $\frac{5-5 x^{5}}{x+2}$
t. $\frac{2-3 t^{3}}{t^{2}+1}$
บ. $\frac{8-3 t^{3}}{5 t^{3}+3}$

\section{BAB 3 :}

\section{DIFERE}

\section{NSIASI}

Capaian Pembelajaran Mata Kuliah :
Mahasiswa
dapat
memahami,
menyelesaikan
dan
mengidentifikasi persoalan
dalam bentuk turunan
fungsi 
Dalam bab ini dibahas mengenai bagaimana suatu besaran berubah dalam hubungannya terhadap besaran lain. Konsep utama kalkululus diferensial ini adalah "turunan" yang merupakan pengembangan dari masalah kecepatan (laju perubahan) serta kemiringan suatu garis singgung kurva.

\subsection{LAJU PERUBAHAN}

Kecepatan dapat dipandang sebagai "laju perubahan". Laju perubahan merupakan laju yang nilainya bisa berisifat positif maupun negatif tergantung dari peningkatan atau penurunan nilai antara dua titik data. Misalkan laju perubahan terhadap waktu, atau dalam istilah lain dapat dikatakan laju perubahan jarak $(s)$ terhadap waktu $(t)$. Laju perubahan dibagi mejadi dua, yaitu laju perubahan rata-rata, dan laju perubahan sesaat.

\section{LAJU PERUBAHAN RATA-RATA}

Definisi 3.1 Jika $y=f(x)$ merupakan laju perubahan rata-rata, maka laju perubahan rata-rata dari $y$ terhadap $x$ pada selang $\left[x_{0}, x_{1}\right]$ adalah kemiringan $m_{P Q}$ dari garis potong yang menghubungkan titik $P\left(x_{0}, f\left(x_{0}\right)\right)$ dan $Q\left(x_{1}, f\left(x_{1}\right)\right)$ pada grafik dan $f$ yaitu 


$$
m_{P Q}=\frac{f\left(x_{1}\right)-f\left(x_{0}\right)}{x_{1}-x_{0}}
$$

\section{Contoh 3.1.}

Diketahui fungsi $f(x)=2 x^{2}+5 x+3$ dengan daerah asal yaitu $\{x \mid x \leq 3\}$. Jika -2 tentukanlah laju perubahan rata-rata fungsi $f(x)$ terhadap $x$ !

\section{Penyelesaian :}

$f(x)=2 x^{2}+5 x+3$

Jika $x=-2$ maka $f(-2)=2(-2)^{2}+5(-2)+3=1$

Jika $x=3$ maka $f(3)=2(3)^{2}+5(3)+3=36$

$m=\frac{f(3)-f(2)}{3-(-2)}=\frac{36-1}{5}=7$

\section{LAJU PERUBAHAN SESAAT}

Definisi 3.2 Jika $y=f(x)$, maka laju perubahan sesaat dari $y$ terhadap $x$ dititik $x_{0}$, adalah kemiringan $m_{\text {tan }}$ dari garis singgung untuk grafik $f$ di titik $x_{0}$ yaitu

$$
m_{\text {tan }}=\frac{f\left(x_{1}\right)-f\left(x_{0}\right)}{x_{1}-x_{0}}
$$

\section{Contoh 3.2 :}

Diketahui suatu persegi panjang dengan panjang $5 x \mathrm{~cm}$ dan lebar $2 x$ $\mathrm{cm}$. tentukan perubahan luas persegi panjang terhadap panjang sisi $x$ ketika $x=4 \mathrm{~cm}$

\section{Penyelesaian :}

Luas persegi panjang adalah $L=p . l=5 x .2 x=10 x^{2}$ 
Fungsi $y=f(x)=L=10 x^{2}$

Dengan menganggap bahwa perubahan panjang sisi persegi berubah pada saat $x=4 \mathrm{~cm}$, maka perubahan sisi persegi panjang menjadi $(x+4)$. Dengan demikian luas perubahan sesaat $L=f(x)$ adalah :

$$
\begin{aligned}
& m_{\tan }=\frac{f(4+x)-f(4)}{x}=\lim _{x \rightarrow 0} \frac{10(4+x)^{2}-10\left(4^{2}\right)}{x} \\
& =\lim _{x \rightarrow 0} \frac{10\left(16+8 x+x^{2}\right)-160}{x}=\lim _{x \rightarrow 0} 80+10 x \\
& =\lim _{x \rightarrow 0} 80+\lim _{x \rightarrow 0} 10 x \\
& =80+0 \\
& =80
\end{aligned}
$$

Jadi perubahan luas terhadap sisi persegi panjang adalah $80 \mathrm{~cm}^{2}$.

\subsection{Turunan Fungsi Aljabar}

Telah dibahas bahwasanya laju perubahan dan kecepatan sesaat merupakan salah satu dari penerapan turunan fungsi.

$$
m_{\text {tan }}=\frac{f\left(x_{1}\right)-f\left(x_{0}\right)}{x_{1}-x_{0}}
$$

Jika $h=x_{1}-x_{0}$, maka untuk $x_{1} \rightarrow x_{0}$ berakibat $h \rightarrow 0$, sehingga dapat dituliskan

$$
m_{\text {tan }}=\frac{f\left(x_{0}+h\right)-f\left(x_{0}\right)}{h}
$$

Fungsi $f^{\prime}$ yang didefinisikan dengan rumus

$$
f^{\prime}=\frac{f\left(x_{0}+h\right)-f\left(x_{0}\right)}{h}
$$


Disebut turunan terhadap $x$ dari fungsi $f$. Domain dari $f^{\prime}$ terdiri dari semua $x$ sehingga limit diatas ada.

\section{NOTASI LAIN}

Fungsi $f^{\prime}$ didefinisikan sebagai turunan suatu fungsi $f$, sedangkan notasi yang lain untuk turunan adalah

$$
f^{\prime}(x)=y^{\prime}=\frac{d y}{d x}=\frac{d f}{d x}=\frac{d}{d x} f(x)=D f(x)=D_{x} f(x)
$$

Lambang $D$ dan $\frac{d}{d x}$ disebut sebagai operator-operator diferensiasi yang menunjukkan proses penghitungan turunan.

Lambang $\frac{d y}{d x}$, diperkenalkan olehGottfriend Leibniz (1646-1716) yang merupakan seorang matematikawan Jerman. Notasi turunan dalam bentuk notasi Leibniz adalah

$$
\frac{d y}{d x}=\frac{\Delta y}{\Delta x}
$$

Yang merupakan notasi lain dalam bentuk $f^{\prime}(x)$. Notasi $f^{\prime}(x)$ diperkenalkan oleh Joseph Louis Lagrange (1736-1813), yang merupakan seorang matematikawan Perancis.

Proses mendapatkan turunan disebut diferensiasi . Diferensiasi dapat dipandang sebagai suatu operasi yang dilakukan pada fungsi $f$ dan menghasilkan $f^{\prime}$.

\section{Contoh 3.3 :}

Andaikan $f(x)=2 x^{2}+3$. Berapakah nilai $f^{\prime}(1)$ !

\section{Penyelesaian :}


$f^{\prime}(x)=\frac{f\left(x_{0}+h\right)-f\left(x_{0}\right)}{h}=\lim _{h \rightarrow 0} \frac{\left(2\left(x_{0}+h\right)^{2}+3\right)-\left(2 x_{0}^{2}+3\right)}{h}=\lim _{h \rightarrow 0} \frac{\left(2\left(x_{0}^{2}+2 x_{0} h+h^{2}\right)+3\right)-2 x_{0}^{2}-2}{h}$ Yang berarti $f^{\prime}\left(x_{0}\right)=4 x_{0}$, dengan demikian $f^{\prime}(x)=4 x$. Nilai dari $f^{\prime}(1)=4$.

\section{HUBUNGAN ANTARA DIFERENSIABILITAS DAN KONTINUITAS}

Menurut definisi turunan merupakan konsep dari limit suatu fungsi. Sehingga turunan pun dapat dilihat dari sisi sebelah kanan $f_{+}^{\prime}$ dan dari sisi sebelah kiri $f_{-}^{\prime}$ yang masing-masing definisinya sesuai dengan definisi turunana.

$$
f_{-}^{\prime}=\frac{f\left(x_{0}+h\right)-f\left(x_{0}\right)}{h} \operatorname{dan} f_{+}^{\prime}=\frac{f\left(x_{0}+h\right)-f\left(x_{0}\right)}{h}
$$

Selanjutnya apabila kemiringan garis didekati $x$ dari arah kanan dan apabila garis potong $x$ didekati dari arah kiri, maka dapat dituliskan secara umum sebagai

$$
f^{\prime}=\frac{f\left(x_{0}+h\right)-f\left(x_{0}\right)}{h}
$$

Perhatikan grafik fungsi berikut 

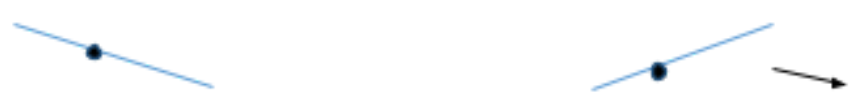

a

b

Kemiringan $=f_{-}^{\prime}$

$$
y=f(x)
$$

Kemiringan $=f_{+}^{\prime}$

Gambar 3.1. Kemiringan Grafik

Definisi 3.3 Fungsi $f$ dikatakan terdeferensial pada selang tertutup $[\mathbf{a}, \mathbf{b}]$ jika syarat-syarat berikut dipenuhi :

a. $f$ terdeferensial pada $(a, b)$

b. $f$ terdeferensial kanan di $a$

c. $f$ terdeferensial kiri di $b$

Diferensiabilitas fungsi terletak pada selang $[a,+\infty),(-\infty, b],(a, b]$.

\subsection{TURUNAN FUNGSI TRIGONOMETRI}


Turunan fungsi Trigonometri digunakan untuk perhitungan dalam dunia nyata, seperti pada bidang Teknik, Fisika dan kehidupan sehari-hari. Sebagaimana pada contoh roda yang berputar, kecepatan titik pada roda tersebut, dll. Oleh karena itu perlu dirumuskan pula turunan untuk fungsi Trigonometri.

\section{TURUNAN FUNGSI SINUS DAN COSINUS}

Jika $f(x)=\sin \sin x$, maka dengan menggunakan rumus turunan dengan rumus definisi turunan sebagai berikut :

$f^{\prime}(x)=\frac{f(x)-f\left(x_{0}\right)}{x-x_{0}}=\lim _{x \rightarrow x_{0}} \frac{\sin \sin (x)-\sin \sin x_{0}}{x-x_{0}}$

$=\lim _{x \rightarrow x_{0}} \frac{2 \cos \cos \left(\frac{x+x_{0}}{2}\right) \sin \sin \left(\frac{x-x_{0}}{2}\right)}{x-x_{0}}$

$=2 \lim _{x \rightarrow x_{0}} \cos \cos \left(\frac{x+x_{0}}{2}\right) \lim _{x \rightarrow x_{0}} \frac{\sin \sin \left(\frac{x-x_{0}}{2}\right)}{x-x_{0}}$

$=2 \cos \cos x_{0} \cdot\left(\frac{1}{2}\right)=\cos \cos x_{0}$

Untuk $f^{\prime}\left(x_{0}\right)=f^{\prime}\left(\sin \sin x_{0}\right)=\cos x_{0}$, maka

$f^{\prime}(x)=f^{\prime}(\sin \sin x)=\cos \cos x$.

Jika $f(x)=\sin \sin x$ dan $g(x)=\cos \cos x, \quad$ keduanya terdefensialkan, maka $f^{\prime}(x)=\cos \cos x$ dan $g^{\prime}(x)=-\sin \sin x$, yaitu :

$$
\frac{d}{d x}(\sin \sin x)=\cos \cos x
$$


Dalam aturan ini dengan mengambil konsep bahwa $\frac{\sin \sin x}{x}=1$ yaitu sehingga dalam pembuktian $\sin \sin x$ diatas adalah $\lim _{x \rightarrow x_{0}} \frac{\sin \sin \left(\frac{x-x_{0}}{2}\right)}{x-x_{0}}=\frac{1}{2}$.

Jika $f(x)=\cos \cos x$, maka dengan menggunakan rumus turunan dengan rumus definisi turunan sebagai berikut :

$f^{\prime}(x)=\frac{f(x)-f\left(x_{0}\right)}{x-x_{0}}=\lim _{x \rightarrow x_{0}} \frac{\cos \cos x-\cos \cos x_{0}}{x-x_{0}}$

$=\lim _{x \rightarrow x_{0}} \frac{-2 \sin \sin \left(\frac{x+x_{0}}{2}\right) \sin \sin \left(\frac{x-x_{0}}{2}\right)}{x-x_{0}}$

$=-2 \lim _{x \rightarrow x_{0}} \sin \sin \left(\frac{x+x_{0}}{2}\right) \lim _{x \rightarrow x_{0}} \frac{\sin \sin \left(\frac{x-x_{0}}{2}\right)}{x-x_{0}}$

$=-2 \sin \sin x_{0} \cdot\left(\frac{1}{2}\right)=x_{0}$

Untuk $\quad f^{\prime}\left(x_{0}\right)=f^{\prime}\left(\cos \cos x_{0}\right)=-\sin x_{0}$,

maka

$f^{\prime}(x)=f^{\prime}(\cos \cos x)=x$

Sama halnya dengan pembuktian fungsi $\sin \sin x$, pada fungsi $\cos \cos x$ juga menerapkan konsep yang sama, bahwasanya $\frac{\sin \sin x}{x}=1$.

Jika $f(x)=\cos \cos x$ dan $g(x)=\sin \sin x, \quad$ keduanya terdefensialkan, maka $f^{\prime}(x)=x$ dan $g^{\prime}(x)=\cos \cos x$, yaitu : $\frac{d}{d x}(\cos \cos x)=x$ 


\section{ATURAN TURUNAN TANGEN, COTANGEN, SECAN, COSECAN}

$\frac{d}{d x} \tan \tan x=\sec ^{2} x \quad \frac{d}{d x} \cot \cot x=-\csc ^{2} x$

$\frac{d}{d x} \sec \sec x=\sec \sec x \tan \tan x$

$\frac{d}{d x} \csc \csc x=-\csc c s c x \cot \cot x$

\subsection{TEKNIK TURUNAN}

Pada bagian ini, akan dibicarakan beberapa Teorema dan teknik turunan untuk beberapa fungsi tertentu yang sudah umum digunakan.

Rumus-Rumus Turunan dan bukti turunannya disajikan dalam teorema berikut :

\section{Teorema 3.4.1.}

$$
\frac{d}{d x}[c]=0
$$

Bukti.

$$
f^{\prime}(x)=\frac{f(x+h)-f(x)}{h}=\lim _{h \rightarrow 0} \frac{c-c}{h}=\lim _{h \rightarrow 0} 0=0
$$

\section{Contoh 3.4 :}

Jika $f(x)=100$, maka $f^{\prime}(x)=0$ untuk semua nilai $x$, yaitu $\frac{d}{d x}[100]=0$

2. Teorema 3.4.2.

$$
\frac{d}{d x}\left[x^{n}\right]=n x^{n-1}
$$

Bukti.

Misalkan $f(x)=x^{n}$, maka

$$
f^{\prime}(x)=\frac{f(x+h)-f(x)}{h}=\lim _{h \rightarrow 0} \frac{(x+h)^{n}-x^{n}}{h}
$$


Dengan menggunakan Teoream Binomial pada $(x+h)^{n}$ diperoleh :

$$
\begin{aligned}
& f^{\prime}(x)=\frac{\left[x^{n}+n x^{n-1} h+n \frac{n-1}{2 !} x^{n-2} h^{2}+\cdots+n x h^{n-1}+h^{n}\right]-x^{n}}{h} \\
& =\frac{\left[n x^{n-1} h+\frac{n(n-1)}{2 !} x^{n-2} h^{2}+\cdots+n x h^{n-1}+h^{n}\right]}{h} \\
& =\lim _{h \rightarrow 0}\left[n x^{n-1} h+\frac{n(n-1)}{2 !} x^{n-2} h^{2}+\cdots+n x h^{n-2}+h^{n-1}\right] \\
& =n x^{n-1}
\end{aligned}
$$

\section{Contoh 3.5 :}

Dapatkan Turunan dari :
a. $f(x)=x^{-5}$
b. $f(x)=x^{10}$
c. $f(x)=x$

\section{Penyelesaian :}
a. $\frac{d}{d x}\left[x^{-5}\right]=-5 x^{-6}$
b. $\frac{d}{d x}\left[x^{10}\right]=10 x^{9}$
c. $\frac{d}{d x}[x]=1 \cdot x^{0}=1$

3. Teorema 3.4.3.

$$
\frac{d}{d x}[c f(x)]=c \frac{d}{d x}[f(x)]
$$

Bukti.

$$
\begin{aligned}
& f^{\prime}(x)=\frac{c f(x+h)-c f(x)}{h}=\lim _{h \rightarrow 0} c\left[\frac{f(x+h)-f(x)}{h}\right] \\
& =c \lim _{h \rightarrow 0} \frac{f(x+h)-f(x)}{h} \\
& =c \frac{d}{d x}[f(x)]
\end{aligned}
$$




\section{Contoh 3.6 :}

Dapatkan Turunan dari fungsi berikut :
a. $f(x)=4 x^{-8}$
b. $f(x)=\frac{1}{2} x^{\frac{1}{2}}$

$$
f(x)=-x^{-2}
$$

c.

\section{Penyelesaian :}
a. $\frac{d}{d x}\left[4 x^{-8}\right]=4 .(-8) x^{-9}=-32 x^{-9}$
b. $\frac{d}{d x}\left[\frac{1}{2} x^{\frac{1}{2}}\right]=\frac{1}{2}\left(\frac{1}{2}\right) x^{-\frac{1}{2}}=\frac{1}{4 x^{2}}$
c. $\frac{d}{d x}\left[-x^{-2}\right]=(-1)(-2) x^{-3}=2 x^{-3}$

\section{Teorema 3.4.4}

$$
\frac{d}{d x}[f(x) \pm g(x)]=\frac{d}{d x}[f(x)] \pm \frac{d}{d x}[g(x)]
$$

Bukti.

$$
\begin{gathered}
\frac{d}{d x}[f(x)+g(x)]=\frac{[f(x+h)+g(x+h)]-[f(x)+g(x)]}{h} \\
=\lim _{h \rightarrow 0} \frac{[f(x+h)-f(x)]+[g(x+h)-g(x)]}{h} \\
=\lim _{h \rightarrow 0} \frac{f(x+h)-f(x)}{h}+\lim _{h \rightarrow 0} \frac{f(x+h)-g(x)}{h} \\
=\frac{d}{d x}[f(x)]+\frac{d}{d x}[g(x)]
\end{gathered}
$$

\section{Contoh 3.7 :}

Dapatkan turunan berikut ini :
a. $\frac{d}{d x}\left[x^{6}+x^{-2}\right]=\frac{d}{d x}\left[x^{6}\right]+\frac{d}{d x}\left[x^{-2}\right]=6 x^{5}-2 x^{-3}$
b. $\frac{d}{d x}\left[5 x^{1 / 3}-x^{2}+3\right]=\frac{d}{d x}\left[5 x^{1 / 3}\right]-\frac{d}{d x}\left[x^{2}\right]+\frac{d}{d x}[3]=\frac{5}{3} x^{-\frac{2}{3}}-2 x$

\section{Teorema 3.4.5}




$$
\frac{d}{d x}[f(x) g(x)]=f(x) \frac{d}{d x}[g(x)]+g(x) \frac{d}{d x}[f(x)]
$$

Bukti.

$$
\frac{d}{d x}[f(x) g(x)]=\frac{f(x+h) g(x+h)-f(x) g(x)}{h}
$$

Jika ditambah dan dikurangi $f(x+h) \cdot g(x)$ pada pembilangnya, maka diperoleh :

$$
\begin{aligned}
& \frac{d}{d x}[f(x) g(x)]=\lim _{h \rightarrow 0} \frac{f(x+h) g(x+h)-f(x+h) g(x)+f(x+h) g(x)-f(x) g(x)}{h} \\
= & \lim _{h \rightarrow 0}\left[f(x+h) \frac{g(x+h)-g(x)}{h}+g(x) \frac{f(x+h)-f(x)}{h}\right] \\
= & \lim _{h \rightarrow 0} f(x+h) \cdot \lim _{h \rightarrow 0} \frac{g(x+h)-g(x)}{h}+\lim _{h \rightarrow 0} g(x) . \lim _{h \rightarrow 0} \frac{f(x+h)-f(x)}{h} \\
= & {[f(x+h)] \frac{d}{d x}[g(x)]+\left[\lim _{h \rightarrow 0} g(x)\right] \frac{d}{d x}[f(x)] }
\end{aligned}
$$$$
\text { Karena } f(x+h)=f(x) \text { dan } g(x)=g(x) \text { diperoleh }
$$$$
\frac{d}{d x}[f(x) g(x)]=f(x) \frac{d}{d x}[g(x)]+g(x) \frac{d}{d x}[f(x)]
$$

\section{Contoh 3.8 :}

Dapatkan Turunan dari fungsi $f(x)=\left(x^{2}-7 x^{1 / 2}\right)\left(3 x^{-3}+2\right)$ !

\section{Penyelesaian :}

$$
\begin{aligned}
& \frac{d}{d x} f(x)=\frac{d}{d x}\left[\left(x^{2}-7 x^{\frac{1}{2}}\right)\left(3 x^{-3}+2\right)\right] \\
& =\left(x^{2}-7 x^{1 / 2}\right) \frac{d}{d x}\left(3 x^{-3}+2\right)+\left(3 x^{-3}+2\right) \frac{d}{d x}\left(x^{2}-7 x^{1 / 2}\right) \\
& =\left(x^{2}-7 x^{1 / 2}\right)\left(-9 x^{-4}\right)+\left(3 x^{-3}+2\right)\left(2 x-\frac{7}{2} x^{-1 / 2}\right) \\
& =\left(-9 x^{-2}+63 x^{-7 / 2}\right)+\left(3 x^{-2}-\frac{21}{2} x^{-\frac{7}{2}}+4 x-7 x^{-1 / 2}\right)
\end{aligned}
$$


$=-6 x^{-2}+\frac{105}{2} x^{-\frac{7}{2}}-7 x^{-\frac{1}{2}}+4 x$

6. Teorema 3.4 .6

$$
\frac{d}{d x}\left[\frac{f(x)}{g(x)}\right]=\frac{g(x) \frac{d}{d x}[f(x)]-f(x) \frac{d}{d x}[g(x)]}{[g(x)]^{2}}
$$

Bukti.

$\frac{d}{d x}\left[\frac{f(x)}{g(x)}\right]=\frac{\frac{f(x+h)}{g(x+h)} g(x)}{h}=\lim _{h \rightarrow 0} \frac{f(x+h) \cdot g(x)-f(x) \cdot g(x+h)}{h \cdot g(x) \cdot g(x+h)}$

Dengan menambahkan dan mengurangkan $f(x) \cdot g(x)$ pada pembilang, diperoleh :

$$
\begin{gathered}
\frac{d}{d x}\left[\frac{f(x)}{g(x)}\right]=\lim _{h \rightarrow 0} \frac{f(x+h) \cdot g(x)-f(x) \cdot g(x)-f(x) \cdot g(x+h)+f(x) \cdot g(x)}{h \cdot g(x) \cdot g(x+h)} \\
=\lim _{h \rightarrow 0} \frac{\left[g(x) \cdot \frac{f(x+h)-f(x)}{h}\right]-\left[f(x) \cdot \frac{g(x+h)-g(x)}{h}\right]}{g(x) \cdot g(x+h)} \\
=\frac{\lim _{h \rightarrow 0} g(x) \cdot \lim _{h \rightarrow 0} \frac{f(x+h)-f(x)}{h} \lim _{h \rightarrow 0} f(x) \cdot \lim _{h \rightarrow 0} \frac{g(x+h)-g(x)}{h}}{\lim _{h \rightarrow 0} g(x) \cdot \lim _{h \rightarrow 0} g(x+h)} \\
=\frac{\lim _{h \rightarrow 0} g(x) \cdot \lim _{h \rightarrow 0}[f(x)]-\lim _{h \rightarrow 0} f(x) \cdot \lim _{h \rightarrow 0}[g(x)]}{\lim _{h \rightarrow 0} g(x) \cdot \lim _{h \rightarrow 0} g(x+h)} \\
\operatorname{Kerana}=g(x)=g(x), \lim _{h \rightarrow 0} f(x)=f(x) \\
\lim _{h \rightarrow 0} g(x+h)=g(x), \operatorname{maka} \\
\frac{d}{d x}\left[\frac{f(x)}{g(x)}\right]=\frac{g(x) \frac{d}{d x}[f(x)]-f(x) \frac{d}{d x}[g(x)]}{[g(x)]^{2}}
\end{gathered}
$$

\section{Contoh 3.9 :}

Misalkan $y=\frac{x^{3}-1}{x^{2}+1}$, dapatkan $\frac{d y}{d x}$ dari fungsi $y$ tersebut!

\section{Penyelesaian :}




$$
\begin{aligned}
& \quad \frac{d y}{d x}=\frac{d}{d x}\left[\frac{x^{3}-1}{x^{2}+1}\right]=\frac{\left(x^{2}+1\right) \frac{d}{d x}\left[x^{3}-1\right]-\left(x^{3}-1\right) \frac{d}{d x}\left[x^{2}+1\right]}{\left(x^{2}+1\right)^{2}} \\
& =\frac{\left(x^{2}+1\right)\left(3 x^{2}\right)-\left(x^{3}-1\right)(2 x)}{\left(x^{2}+1\right)^{2}} \\
& =\frac{3 x^{4}+3 x^{2}-\left(2 x^{4}-2 x\right)}{\left(x^{2}+1\right)^{2}} \\
& =\frac{x^{4}+3 x^{2}+2 x}{\left(x^{2}+1\right)^{2}}
\end{aligned}
$$

\section{SOAL LATIHAN}

1. Gunakan definisi Turunan dengan menggunakan limit fungsi untuk mendapatkan $f^{\prime}(x)$ !
a. $f(x)=x^{1 / 2}$
b. $f(x)=1 / \sqrt{x}$
c. $f(x)=1 / x^{2}$
d. $f(x)=\sqrt[3]{x}$

2. Pergunakan Teorema-Teorema yang sesuai untuk mendapatkan deferensiasi dari fungsi yang diberikan.
a. $y=\left(x^{3}-2 x^{2}+x-3\right)\left(\frac{2 x}{x^{5}}\right)$
b. $y=5 x+\frac{1}{x^{5}}$
c. $f(x)=\left(x^{3}+3 x^{2}\right)^{2}$
d. $f(x)=\left(2 x^{5}-x^{2}\right)\left(\frac{x+1}{x^{2}-1}\right)$
e. $y=\frac{x^{-7}}{x^{3}+2}$
f. $y=\left(\frac{1}{x}+\frac{1}{x^{3}}\right)\left(5 x^{4}+2 x\right)$ 
3. Jika diketahui $f(5)=1, f^{\prime}(5)=6, g(5)=-3$ dan $g^{\prime}(5)=2$, dapatkan $F^{\prime}(5)$ apabila:
a. $F(x)=5 f(x)+3 g(x)$
b. $F(x)=f(x) g(x)$
c. $F(x)=3 f(x)-5 g(x)$
d. $F(x)=f(x) / g(x)$
e. $F(x)=3 f^{\prime}(5)-2 f(5) f(x)+g^{\prime}(5) g(x)$

4. Dapatkan persamaan garis singgung pada grafik dari $y=f(x)$ di titik dengan $x=-3$ jika $f(-3)=2$ dan $f^{\prime}(-3)=5$.

5. Dapatkan persamaan garis yang menyinggung $y=(1-x) /(1+x)$ di titik dengan $x=2$.

6. Dapatkan koordinat- $x$ dari titik pada grafik $y=1-x^{2}$ dengan garis singgungnya di titik tersebut melalui titik $(2,0)$

7. Dapatkan $f^{\prime}(x)$ dari fungsi berikut:
a. $f(x)=\frac{\sin \sin x}{\tan \tan x}$
b. $f(x)=\frac{\operatorname{csccsc} x}{\tan \tan x}$
c. $f(x)=\frac{\sin \sin x \operatorname{secsec} x}{1+x \tan \tan x}$
d. $f(x)=\frac{\operatorname{secsec} x}{1+\tan \tan x}$
e. $f(x)=\frac{\tan \tan x}{\sin \sin x \cos \cos x}$

\subsection{ATURAN RANTAI}

Andaikan diberikan soal $y=\left(x^{2}+3\right)^{11}$ dan kita disuruh untuk menyelesaikan dengan rumus turunan yang telah didefinisikan, maka soal tersebut tidak dapat terselesaikan dan kita tidak dapat menemukan $y^{\prime}$. Apabila diamati, fungsi $y$ tersebut merupakan fungsi komposisi. Andaikan $y=f(u)=u^{11}$ dan $u=g(x)=x^{2}+3$ maka dapat ditulis $y=F(x)=f(g(x))$, yaitu $F(x)=(f \circ g)(x)$. 
Turunan fungsi komposisi merupakan hasil kali turunan $f$ terhadap $u$ dengan turunan $g$ terhadap $x$.

Teorema 3.5. Jika $g$ terdeferensial di titik $x$ dan $f$ terdeferensial di titik $g(x)$, maka komposisi $f o g$ terdeferensialdi titik $x$ dengan

$$
\frac{d y}{d x}=\frac{d y}{d u} \cdot \frac{d u}{d x}
$$

Agar lebih memahami aturan rantai ini, maka diberikan beberapa contoh penggunaan aturan rantai di dalam soal.

\section{Contoh 3.10 :}

Tentukan turunan dari $y=\left(x^{2}+2 x-3\right)^{11}$ !

\section{Penyelesaian :}

Misalkan $u=x^{2}+2 x-3$, maka $y=u^{11}$ akibatnya dengan menggunakan rumus aturan rantai diperoleh

$$
\begin{aligned}
\frac{d y}{d x} & =\frac{d y}{d u} \cdot \frac{d u}{d x} \\
& =\frac{d}{d u}\left(u^{11}\right) \cdot \frac{d}{d x} x^{2}+2 x-3 \\
& =11 u^{10}(2 x+2) \\
& =11\left(x^{2}+2 x-3\right)^{10}(2 x+2)
\end{aligned}
$$

\section{Contoh 3.11 :}

Dapatkan $\frac{d y}{d x}$ Jika $y=\sqrt{x^{2}+3}$ !

\section{Penyelesaian :}


Misal $u=x^{2}+3$, maka $y=\sqrt{u}$

Dengan aturan rantai :

$$
\begin{aligned}
\frac{d y}{d x} & =\frac{d y}{d u} \cdot \frac{d u}{d x}=\frac{d}{d u} \sqrt{u} \cdot \frac{d}{d x} x^{2}+3 \\
& =\frac{1}{2} u^{-\frac{1}{2}}(2 x)=\frac{2 x}{2\left(x^{2}+3\right)^{2}}
\end{aligned}
$$

\section{Contoh 3.12 :}

Dapatkan turunan dari $y=4 \tan \tan \left(x^{2}-1\right)$ !

\section{Penyelesaian :}

Misal $u=\left(x^{2}-1\right)$, maka $y=4 \tan \tan u$, sehingga dengan rumus aturan rantai :

$$
\begin{aligned}
& \frac{d y}{d x}=\frac{d y}{d u} \cdot \frac{d u}{d x}=\frac{d}{d u} 4 \tan \tan u \cdot \frac{d}{d x}\left(x^{2}-1\right)=4 \sec ^{2} u(2 x) \\
& =4 \sec ^{2}\left(x^{2}-1\right) 2 x=8 x \sec ^{2}\left(x^{2}-1\right)
\end{aligned}
$$

\section{Contoh 3.13 :}

Jika $y=\left(\frac{3 x}{x^{2}-1}\right)^{7}$, tentukan $\frac{d y}{d x}$ !

\section{Penyelesaian :}

Misal $u=\frac{3 x}{x^{2}-1}$, maka $y=u^{7}$, dengan menggunakan rumus aturan rantai :

$$
\frac{d y}{d x}=\frac{d y}{d u} \cdot \frac{d u}{d x}=\frac{d}{d u} u^{7} \cdot \frac{d}{d x}\left(\frac{3 x}{x^{2}-1}\right)=7 u^{6}\left(\frac{\left(x^{2}-1\right)(3)-3 x(2 x)}{\left(x^{2}-1\right)^{2}}\right)
$$




$$
=7\left(\frac{3 x}{x^{2}-1}\right)^{6}\left(\frac{3 x^{2}-3-6 x^{2}}{\left(x^{2}-1\right)^{2}}\right)=7\left(\frac{3 x}{x^{2}-1}\right)^{6}\left(\frac{-3 x^{2}-3}{\left(x^{2}-1\right)^{2}}\right)
$$

\section{Contoh 3.14 :}

Dapatkan
a. $\frac{d y}{d x} \sqrt{\sin \sin (5 x+2)}$
b.

$$
\frac{d y}{d x} \cos \cos (\sin \sin (2 x+1))
$$

\section{Penyelesaian :}

Penyelesaian a.

Misal $u=\sin \sin 5 x+2$, maka $y=\sqrt{u}$, dengan aturan rantai diperoleh

$\frac{d y}{d x}=\frac{d}{d u} \sqrt{u} \cdot \frac{d u}{d x}=\frac{1}{2} u^{-1 / 2} \cdot \frac{d u}{d x}$

Dengan cara yang sama menggunakan aturan rantai, maka $u$ menjadi

$\frac{d u}{d x}=\frac{d}{d x} \sin \sin (5 x+2)=(5 x+2)$

Sehingga

$$
\begin{aligned}
& \frac{d y}{d x}=\frac{d}{d u} \sqrt{u} \cdot \frac{d u}{d x}=\frac{1}{2} u^{-\frac{1}{2}} \cdot(5 x+2) \\
& =\frac{5}{2} \sin \sin (5 x+2)^{-1 / 2} \cos \cos (5 x+2)=\frac{5 \cos \cos (5 x+2)}{2 \sqrt{\sin \sin (5 x+2)}}
\end{aligned}
$$

Penyelesaian b.

Misal $u=\sin \sin (2 x+1)$, maka $y=\cos \cos u$, sehingga dengan rumus aturan rantai menjadi : 
$\frac{d y}{d x}=\frac{d}{d u} \cos \cos u \cdot \frac{d}{d x} \sin \sin (2 x+1)=(-\sin \sin u) \cdot(2 \cos \cos (2 x+1)$

$=-2 \sin (\sin \sin (2 x+1)) \cos (2 x+1)$

$=-\sin \sin [2 \sin \sin (2 x+1) \cos \cos (2 x+1)]$

$=-\sin \sin (\sin \sin 2(2 x+1))=-\sin \sin [\sin \sin (4 x+2)]$

\section{SOAL LATIHAN}

Carilat turunan dari fungsi yang diberikan berikut ini :

1. $f(x)=\left(x^{5}-3 x^{3}+2 x+1\right)^{21}$

2. $f(t)=\left(t^{2}-\frac{1}{t^{3}}\right)^{-3}$

3. $f(s)=\frac{1}{\left(s^{3}-2 s-3\right)^{7}}$

4. $f(y)=\sqrt{5+3 \sqrt{y^{3}}}$

5. $f(z)=\cos \cos \left(\frac{1}{1-z^{2}}\right)$

6. $f(x)=x^{3} \tan \tan \left(x^{3}+3\right)^{2}$

7. $y=\tan \tan \sin \sin (3 x)$

8. $y=\left[x+\csc \csc \left(x^{2}+3 x+2\right)\right]^{-2}$

9. $f(x)=\sin ^{3}\left(\frac{x}{x^{2}-1}\right)$

10. $f(x)=\frac{\sin \sin x}{\operatorname{csccsc}(2 x+1)^{2}}$

11. $f(t)=\sqrt[5]{\frac{t^{2}-1}{t^{3}+1}}$

12. $f(x)=\sqrt{x+\sqrt{x+\sqrt{x}}}$

13. $f(x)=\frac{1+\operatorname{cscsc}\left(x^{2}-1\right)}{1+\tan \tan \left(x^{2}+1\right)}$ 
14. $y=\left[x^{3}+\csc c s c\left(x^{3}-2 x\right)\right]^{-3}$

15. $f(t)=\sin ^{3}\left(x^{3}+3 x-1\right)$

\subsection{TURUNAN FUNGSI IMPLISIT}

Fungsi implisit merupakan suatu fungsi dimana peubah tak bebas dan peubah bebas tidak dapat dipisahkan satu sama lain dan dinyatkan dengan $f(x, y)=0$. Dengan demikian, diferensiasi atau turunannya dilakukan pada kedua sisi dengan memandang $y$ sebagai fungsi dari $x$ dan juga tidak dapat dihindarkan bahwa digunakan pula aturan rantai dalam proses perhitungannya. Turunan fungsi implisit ini berguna dalam penerapan Turunan yang nantinya akan diterapkan dalam persoalan yang berkaitan.

\section{Contoh 3.15 :}

Dengan turunan implisit, dapatkan $\frac{d y}{d x}$ jika $6 y^{2}+y=2 x^{2} !$

\section{Penyelesaian :}

Dengan menerapkan turunan pada kedua sisi terhadap $x$ dan $y$ sebagau fungsi dari $x$, diperoleh

$$
\begin{aligned}
& \frac{d}{d x}\left[6 y^{2}+y\right]=\frac{d}{d x}\left[2 x^{2}\right] \\
& \frac{d}{d x}\left[6 y^{2}+y\right] \frac{d y}{d x}=4 x
\end{aligned}
$$

Aturan rantai digunakan disisi kiri karena $y$ fungsi dari $x$, sehingga $(6(2 y)+(3 \cos \cos y)) \frac{d y}{d x}=4 x$

$(12 y+3 \cos \cos y) \frac{d y}{d x}=4 x$

Diselesaikan untuk $\frac{d y}{d x}$, diperoleh 
$\frac{d y}{d x}=\frac{4 x}{12 y+3 \cos \cos y}$

Pada contoh 3.15 diatas, soal memuat peubah $x$ dan $y$ sekaligus.

Untuk memperoleh $\frac{d y}{d x}$ dalam peubah $x$ saja, maka $y$ harus dinyatakan secara eksplisit sebagi fungsi dari $x$. Akan tetapi hal ini tidak dapat dilakukan karena $\frac{d y}{d x}$ tetap memuat peubah $x$ dan $y$. Dalam penerapan turunan, $\frac{d y}{d x}$ biasanya dicari di suatu titik $(x, y)$ yang telah diketahui, sehingga $\frac{d y}{d x}$ dapat ditentukan nilainya.

\section{Contoh 3.16 :}

Dapatkan kemiringan garis singgung di titik $(2,0)$ pada kurva $3 y^{3}+x^{2} y-x^{3}=6$ !

\section{Penyelesaian :}

Tidak mudah menyelesaikan soal diatas apabila $y$ dinyatakan dalam $x$, sehingga turunannya dicari secara implisit.

$$
\begin{aligned}
& \frac{d}{d x}\left[3 y^{3}+x^{2} y-x^{3}\right]=\frac{d}{d x}[6] \\
& \frac{d}{d x}\left[3 y^{3}\right]+\frac{d}{d x}\left[x^{2} y\right]-\frac{d}{d x}\left[x^{3}\right]=0 \\
& \frac{d}{d x}\left[3 y^{3}\right] \frac{d y}{d x}+\left(x^{2} \frac{d y}{d x}+y \frac{d}{d x}\left[x^{2}\right]\right)-\frac{d}{d x}\left[x^{3}\right]=0 \\
& 9 y^{2} \frac{d y}{d x}+x^{2} \frac{d y}{d x}+2 y x-3 x^{2}=0
\end{aligned}
$$

Dengan menyelesaikan ke $\frac{d y}{d x}$, diperoleh

$$
\left(9 y^{2}+x^{2}\right) \frac{d y}{d x}=3 x^{2}-2 x y
$$


$\frac{d y}{d x}=\frac{3 x^{2}-2 x y}{9 y^{2}+x^{2}}$

Di titik (2,0), diperoleh :

$m_{\text {tan }}=\left.\frac{d y}{d x}\right|_{x=2 y=0}=\frac{3 x^{2}-2 x y}{9 y^{2}+x^{2}}=\frac{3(2)^{2}-2(2)(0)}{9(0)^{2}+(2)^{2}}=\frac{12}{4}=3$

\section{Contoh 3.17 :}

Gunakan diferensiasi implisit untuk mendapatkan $\frac{d^{2} y}{d x^{2}}$ jika $x^{2}-4 y^{3}=100 !$

\section{Penyelesaian :}

Dengan diferensiasi pada kedua sisi $x^{2}-4 y^{3}=100$ diperoleh

$\frac{d}{d x}\left[x^{2}-4 y^{3}\right]=\frac{d}{d x}[100]$

$\frac{d}{d x}\left[x^{2}\right]-4 \frac{d}{d x}\left[y^{3}\right]=0$

$2 x-4\left(3 y^{2}\right) \frac{d y}{d x}=0$

$\frac{d y}{d x}=-\frac{2 x}{12 y^{2}}$

Dengan diferensiasi kedua sisi pada $\frac{d y}{d x}$ diatas, diperoleh

$\frac{d^{2} y}{d x^{2}}=-\frac{12 y^{2} \frac{d}{d x}[2 x]-2 x \frac{d}{d x} 12 y^{2}}{\left[12 y^{2}\right]^{2}}=-\frac{21 y^{2}-48 x y \frac{d y}{d x}}{144 y^{4}}$

Karena nilai $\frac{d y}{d x}$ telah diperoleh pada perhitungan sebelumnya, maka disubstitusikan keladam $\frac{d^{2} y}{d x^{2}}$ mejadi 


$$
\frac{d^{2} y}{d x^{2}}=-\frac{21 y^{2}-48 x y\left(-\frac{2 x}{12 y^{2}}\right)}{144 y^{4}}=-\frac{21 y^{2}+8 \frac{x}{y^{2}}}{144 y^{2}}=-\frac{21 y^{4}+8 x}{144 y^{2}}
$$

\section{SOAL LATIHAN}

1. Dengan menggunakan turunan implisit, carilah $y^{\prime}$ pada fungsi yang diberikan berikut ini :
a. $\sqrt{x y}+\sqrt{x}-\sqrt{y}=4$
b. $\frac{1}{x}+\frac{1}{y}=1$
c. $\frac{x}{x+y}=x^{2}-1$
d. $x^{2} y+2 y+3 x^{2}=4$
e. $3 x y-x y^{2}-4=0$

2. Dapatkan $\frac{d y}{d x}$ dengan menggunakan diferensiasi implisit :
a. $x^{2}+y^{2}=100$
b. $3 x^{2} y=\left(x^{2}+y^{3}\right)^{1 / 2}$
c. $\sin \sin x y=x$
d. $\cos \cos x y^{2}=y$
e. $x^{3} y+x y^{3}+5 x y=3 x$
f. $\sqrt{x+y}=10$
g. $\left(x^{2}+3 y^{2}\right)^{99}=x$
h. $\cos \cos \left(x^{2} y^{2}\right)=y$
i. $\sin \sin x+\cos \cos y=\sin \sin x \cos \cos x y$
j. $\quad x^{2}=\frac{\cos \cos y}{1+\sin \sin y}$
k. $\frac{x y^{3}}{1+\tan \tan y}=1+y^{2}$
I. $\frac{\cot \cot y}{1+\operatorname{secsec} y}=x^{3} y$ 

m. $x^{3} y^{2}-5 x^{2} y+x y=1$
n. $\sqrt{x y}+7 y=x$

\section{BAB 4 :}

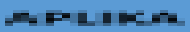

$=$

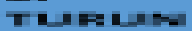

프물

Capaian Perntelajaran Nata Kuliah =

Mahasiswa

dapat:

momahami.

menyelesaikan dan

mengidentifikasi persoalan

dalam bentuk turunan

fungsi

Mahasiswa

dapat

menganalisis

dan

menerapkan

aplikasi

turunan

dalam

permasalahan teknik. 


\subsection{LAJU YANG BERKAITAN}

Pada bab ini dipelajari mengenai laju-laju yang berkaitan antara besaran satu dengan besaran lain yang saling berkaitan sehingga satu sama lain tidak dapat dipisahkan.

\section{Contoh 4.1 :}

Seorang anak minum air dari gelas yang berbentuk seperti kerucut dengan menggunakan sebuah sedotan plastik, yang sumbunya tegak lurus terhadap gelas. Tinggi gelas kerucut adalah $10 \mathrm{dm}$, dan jari-jari dasar gelas $3 \mathrm{dm}$. Mula-mula diasumsikan gelas penuh berisi air, anak menyedot air dari dalam gelas dengan kecepatan $3 \mathrm{dm}^{3} /$ menit. Berapa cepatkah air di dalam gelas berkurag ketika ketinggian air dalam gelas mencapai $5 \mathrm{dm}$ ?

\section{Penyelesaian :}

Langakah 1 : Gambarkan Soal dan beri label besaran yang diketahui pada soal
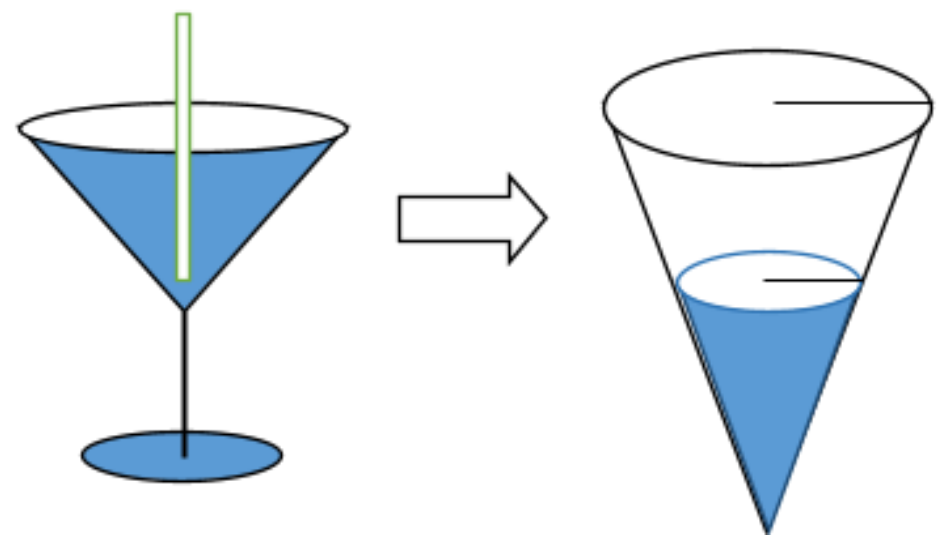
$10 \mathrm{dm}$

$3 \mathrm{~cm}$

$5 \mathrm{dm}$

\section{Gambar 4.1 Volume Air dalam Gelas}

Langkah 2 : identifikasi laju-laju perubahan yang diketahui dan laju perubahan yang akan dicari

Diketahui :

$y_{1}=10 \mathrm{dm}$

$y_{2}=5 \mathrm{dm}$

$x=3 \mathrm{dm}$

$\frac{d V}{d t}=-3 \mathrm{dm}^{3} /$ menit (Tanda minus berarti volume air dalam gelas berkurang)

Langkah 3 : Tuliskan pertanyaan dalam bentuk model matematika berupa turunan fungsi

Ditanya : $\left.\frac{d y}{d t}\right|_{3}$

Langkah 4 : Tentukan persamaan yang mengaitkan kuantitas laju perubahan yang dicari dengan kuantitas yang laju perubahannya diketahui

Jawab :

Dari rumus volume kerucut, volume $\mathrm{V}$, dan jari-jari $x$, kedalaman $y$ dihubungkan oleh : 


$$
V=\frac{1}{3} \pi x^{2} y
$$

Jika kedua sisi diturunkan terhadap $t$ sisi kanan melibatkan besaran $d x / d t$. Karena tidak ada informasi tentang $d x / d t$ maka $x$ perlu dieliminasi sebelum penurunan. Hal ini dapat dikerjakan dengan persamaan segitiga menggunakan rumus perbandingan geometri :

$\frac{x}{y}=\frac{3}{10}$ atau $x=\frac{3}{10} y$

Substitusi persamaaan ini kedalam rumus Volume kerucut, menghasilkan :

$V=\frac{1}{3} \pi\left(\frac{3}{10} y\right)^{2} y$ atau $\quad V=\frac{9}{100} \pi y^{3}$

Langkah 5 : Turunkan kedua sisi persamaan itu terhadap waktu dan selesaikan turunan yang akan memberilaju perubahan yang belum diketahui.

Penurunan kedua sisi terhadap $t$ diperoleh :

$$
\begin{gathered}
\frac{d V}{d t}=\frac{9 \pi}{100}\left(3 y^{2} \frac{d y}{d t}\right)=\frac{27 \pi y^{2}}{100} \frac{d y}{d t} \\
\frac{d y}{d t}=\frac{100}{27 \pi y^{2}} \frac{d V}{d t}
\end{gathered}
$$

Dengan subsitusi nilai $y=3$, diperoleh :

$$
\left.\frac{d y}{d t}\right|_{3}=\frac{-12}{27 \pi}=-\frac{-4}{9 \pi} \mathrm{dm} / \text { menit }
$$

Sehingga kedalaman air dlam gelas berkurang dengan laju sekitar $0.141 \mathrm{dm} /$ menit (tanda minus menandakan air dalam gelas semakin berkurang)

\section{Contoh 4.2 :}


Sebuah kapal pengangkut minyak mengalami kebocoran dan tumpahan minyaknya menyebar di lautan dalam bentuk lingkaran dengan jari-jari yang selalu bertambah dengan laju konstan 2 $\mathrm{m} /$ detik. Seberapa cepatkah luas daerah tumpahan bertambah ketika jari-jari pancaran $70 \mathrm{~m}$ ?

\section{Penyelesaian :}

Petunjuk : Untuk menyelesaikan masalah seperti di atas, dapat dilakukan dengan langkah langkah sebagai berikut :

Langkah 1 : Gambar dan Beri label besaran yang berubah

Penyebaran tumpahan minyak terlihat seperti Gambar 4.2. berikut

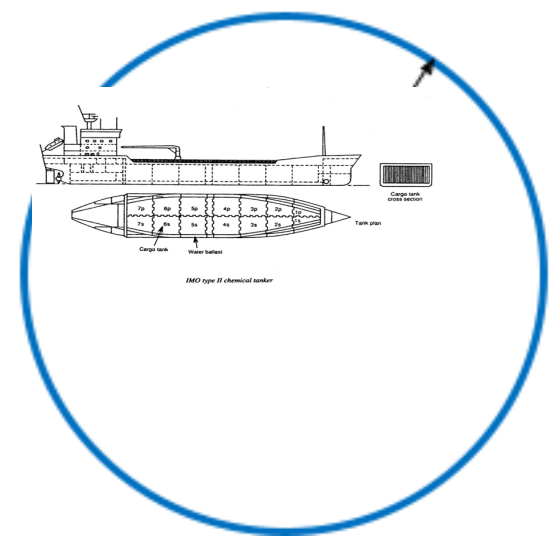

Gambar 4.2. Daerah Tumpahan Minyak

Misalkan :

$t$ = waktu (dalam detik) yang diperlukan untuk menumpahkan minyak

$r$ = jari-jari tumpahan minyak (dalam meter) setelah $t$ detik 
$L=$ Luas daerah tumpahan minyak (dalam meter persegi) setelah $t$ detik

Langkah 2 : Identifikasi laju-laju perubahannya diketahui dari laju perubahan yang akan di cari

Notasi $\frac{d r}{d t}$ menyatakan laju perubahan jari-jari terhadap waktu besarnya $2 \mathrm{~m} /$ detik

Notasi $\frac{d L}{d t}$ menyatakan laju pertamabahan luas terhadap waktu yang akan di cari. Jadi dinyatakan dengan $\left.\frac{d L}{d t}\right|_{r=70}$

Langkah 3 : Tentuka persamaan yang mengaitkan kuantitas yang laju perubahan luasnya dicari dengan kuantitas yang laju perubahannya diketahui. Dari rumus luas lingkaran diperoleh $L=\pi r^{2}$

Langakah 4 : Turunkan kedua sisis persamaan itu kedalam fungsi waktu, dan selesaikan turunnannya yang akan memberi laju perubahan yang tidak diketahui. Bila $L$ dan $r$ adalah fungsi dari $t$, maka kedua sisi dapat diturunkan terhadap $t$ untuk memperoleh

$$
\frac{d L}{d t}=2 \pi r \frac{d r}{d t}
$$

Langkah 5 : Evaluasi turunan dititik yang dimaksud

$$
\left.\frac{d L}{d t}\right|_{r=70}=2 \pi(70)(2)=280 \mathrm{~m}^{2} / \text { det }
$$

Jadi pada saat $r=70$ daerah tumpahan bertambah dengan laju $280 \mathrm{~m}^{2} / \mathrm{det}$

\section{Contoh 4.3 :}


Sebuah tangga yang panjangnya $5 \mathrm{~m}$ bersandar pada tembok. Lantai tersebut licin, sehingga tangga tersebut tergelincir sedemikian hingga bagian bawah tangga bergerak menjauhi dinding dengan laju $3 \mathrm{~m} / \mathrm{s}$ ketika bagian bawah berjarak $4 \mathrm{~m}$ dari dinding. Berapa cepat bagian atas turun ke bawah?

\section{Penyelesaian :}

Misalkan :

$t=$ waktu (dalam detik) setelah tangga mulai tergelincir

$x=$ jarak (dalam meter) bagian bawah tangga ke dinding

$y=$ jarak (dalam meter) bagian atas taangga ke lantai

Setiap saat laju bagian bawah tangga adalah $\frac{d x}{d t}$ sedangkan laju bagian atas $\frac{d y}{d t}$ akan dicari

$\left.\frac{d y}{d t}\right|_{x=4}$ jika diketahui $\left.\frac{d x}{d t}\right|_{x=4}=3 \mathrm{~m} / \mathrm{s}$

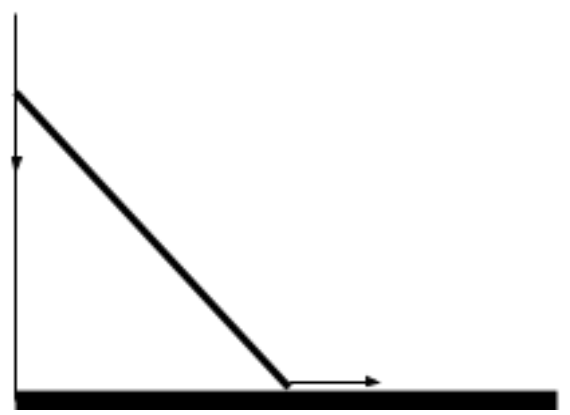

Tembok

Tangga $5 \mathrm{~m}$

$3 \mathrm{~m} / \mathrm{s}$ 
Gambar 4.3. Tangga Bersandar di dinding

Berdasarkan Teorema Pytagoras

$$
x^{2}+y^{2}=25
$$

Penguunaan aturan berantai untuk menurunkan kedua sisi terhadap $t$ menghasilkan

$$
2 x \frac{d x}{d t}+2 y \frac{d y}{d t}=\text { Atau } \frac{d y}{d t}=-\frac{x}{y} \frac{d x}{d t}
$$

Jika $x=4$ maka diperoleh $y=3$, karena $\frac{d x}{d t}=3$, sehingga menghasilkan

$$
\left.\frac{d y}{d t}\right|_{x=4}=-\frac{4}{3}(3)=-4 \mathrm{~m} / \mathrm{s}
$$

Tanda negatif menunjukkan bahwa $y$ berkurang, yang secara fisik berarti puncak tangga pada dinding bergerak ke bawah.

\section{SOAL LATIHAN}

1. Batu dijatuhakn ke kolam tenang menghasilkan riak berbentuk lingkaran yang jari-jarinya bertambah dengan laju $2 \mathrm{~m} / \mathrm{det}$. Berapa cepat laju luas yang akan tertutupi riak bertambah pada akhir 10 detik?

2. Perahu ditarik ke dok dengan tali yang digantungkan pada kerekan dok seperti pada Gambar 5.1.4. Tali digantungkan pada haluan perahu di titik $10 \mathrm{~m}$ dibawah kerekan. Jika tali ditarik melalui kerekan dengan laju $24 \mathrm{~m} /$ menit, dengan laju berapa perahu mendekati dok jika tali yang keluar $125 \mathrm{~m}$ ? 


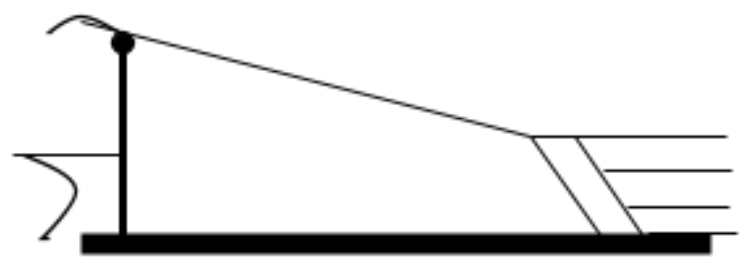

Perahu

kerekan

dok

Gambar 4.4. Perahu ditarik ke dok

3. Balon Bulat membumbung tinggi dan volume balon tersebut bertambang dengan laju $3 \mathrm{~cm}^{3} /$ menit. Berapa cepat laju diameter balon bertambah bila jari jari $8 \mathrm{~cm}$ ?

4. Seorang laki laki tingginya $1,8 \mathrm{~m}$ berjalan dengan laju 0,75 $\mathrm{m} /$ detik menuju lampu jalan dengan ketinggian $18 \mathrm{~m}$ (Gambar 4.5)

a. Berapa laju panjang bayangan bergerak?

b. Berapa cepat ujung bayangannya bergerak?

5. Suatu pesawat terbang pada ketinggian konstan dengan kecepatan $600 \mathrm{mil} / \mathrm{jam}$. Sebuah peluru kendali penangkis pesawat udara ditembankkan pada garis lurus yang tegak lurus lintasan pesawat, sehingga akan menghancurkan pesawat di titik P. Pada saat itu pesawat bergerak 2 mil dari titik $P$, dan peluru kemdali terletak 4 mil dari $P$ terbang dengan kecepatan 1200 mil/jam. Pada saat itu berapa cepat jarak antara pesawat dan peluru kendali berubah? 


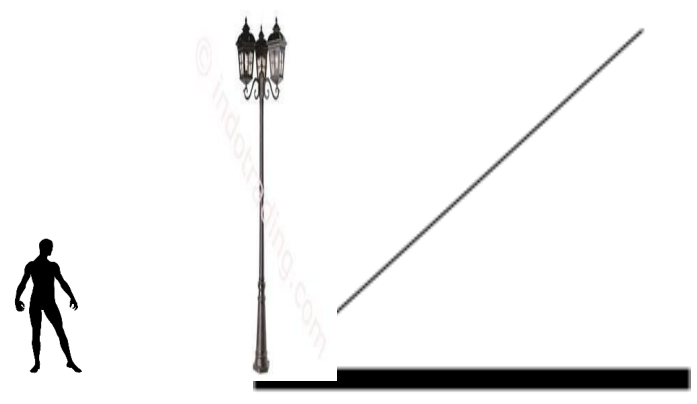

Gambar 4.5. Orang Berjalan Menuju Lampu Jalan

\subsection{SELANG NAIK, SELANG TURUN, DAN KECEKUNGAN FUNGSI}

Selang merupakan himpunan dari titik pada batas bawah suatu titik sampai pada batas atas titik yang menjadi acuan. Penggambaran titik-titik sangat berguna untuk mengetahui bentuk umum suatu grafik fungsi. Akan tetapi bentuk grafik yang diapatkan dari pengeplotan titik-titik hanya memberikan hampiran grafik. Hal ini dikarenakan berapapun titik yang di plotkkan, bentuk grafik hanya berupa perkiraan. Pada sub-bab ini akan ditunjukkan penggunaan turunan untuk menyelesaikan kerumatian seperti penjabaran diatas.

naik

turun 
naik

konstan

0

2

4

5

Gambar 4.6. Fungsi Naik Turun dan Konstan

Dari Gambar 4.6 diatas, terdapat fungsi yang naik, turun dan konstan.

\section{SELANG NAIK DAN SELANG TURUN}

Fungsi naik, turun dan konstan digunakan untuk menggambarkan sifat fungsi pada suatu selang dari kiri ke kanan sepanjang grafik. Pada Gambar 4.6. fungsi naik pada selang $(-\infty, 0]$, turun pada selang $[0,2]$, naik lagi pada selang $[2,5]$, dan fungsi konstan pada selang $[5,+\infty)$.

Berikut ini merupakan gambaran umum tentang naik, turun, dan konstan suatu fungsi.

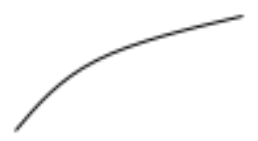


naik

turun

konstan

a

b

$\mathrm{a}$

b

a

$\mathrm{b}$

$f(a)$

$f(a)$

$f(a)$

$f(b)$

$f(b)$

$f(b)$

(a)

(b)

(c)

Gambar 4.7. Definisi Naik Turun dan Konstan

Berdasarkan definisi yang dapat disimpulkan dari Gambar 4.7. diatas adalah : 
Misalkan $f$ didefinisikan pada selang tertentu, dan $a, b$ meyatakan titik-titik pada selang tersebut, maka

a. $\quad f$ naik pada selang itu jika $f(a)<f(b)$ untuk $a<b$

b. $\quad f$ turun pada selang itu jika $f(x)>f(b)$ untuk $a<b$

c. $\quad f$ konstan pada selang itu jika $f(a)=f(b)$ untuk semua $a$ dan $b$

Fungsi $f$ naik pada suatu selang jika grafiknya mempunyai garis singgung dengan kemiringan posotif dan turun jika grafiknya mempunyai garis singgung dengan kemiringan negatif dan konstan jika grafiknya mempunyai garis singgung dengan kemiringan nol.
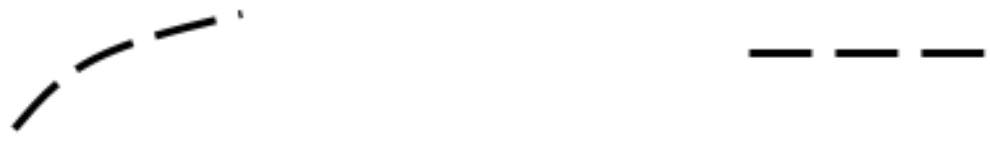

naik

turun

konstan

a

b

a

$\mathrm{b}$ 


$$
\begin{aligned}
& m=+ \\
& m=0 \\
& m=-
\end{aligned}
$$

(a)

(b)

(c)

Gambar 4.8. Kemiringan Garis Singgung Grafik Fungsi

Misalkan $f$ suatu fungsi kontinu pada selang tertutup $[a, b]$ dan dapat diturunkan pada selang terbuka $(a, b)$, maka

a. Jika $f^{\prime}(x)>0$ untuk setiap nilai $x$ dalam $(a, b)$ maka $f$ naik pada $[a, b]$

b. Jika $f^{\prime}(x)<0$ untuk setiap nilai $x$ dalam $(a, b)$ maka $f$ turun pada $[a, b]$

c. Jika $f^{\prime}(x)=0$ untuk setiap nilai $x$ dalam $(a, b)$ maka $f$ konstan pada $[a, b]$

\section{Contoh 4.4 :}

Tentukan selang yang menyebabkan fungsi berikut naik, dan selang yang menyebabkan fungsi turun :
a. $\quad f(x)=x^{2}-3 x-4$
b. $f(x)=x^{3}$

\section{Penyelesaian :}


Penyelesaian a.

Penurunan $f$ akan diperoleh

$$
\begin{gathered}
f^{\prime}(x)=2 x-3 \\
2 x-3=0 \rightarrow x=\frac{3}{2}
\end{gathered}
$$

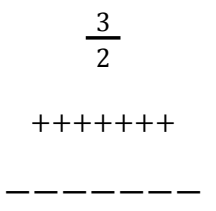

Gambar 4.9. Tanda dari $f^{\prime}(x)$

Selanjutnya, dari analisa pada Gambar 4.9 diperoleh

$f^{\prime}(x)<0$ jika $-\infty<x<3 / 2$

$f^{\prime}(x)>0$ jika $3 / 2<x<+\infty$

Karena $f$ kontinu di $x=3 / 2$ menurut definisi maka

$f$ turun pada $\left(-\infty, \frac{3}{2}\right]$

$f$ naik pada $\left[\frac{3}{2},+\infty\right)$ 


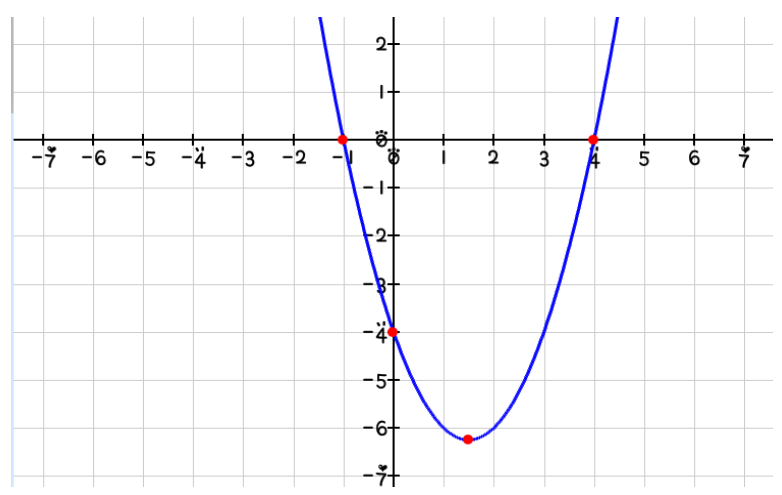

Gambar 4.10. Fungsi $f(x)=x^{2}-3 x-4$

Penyelesaian b.

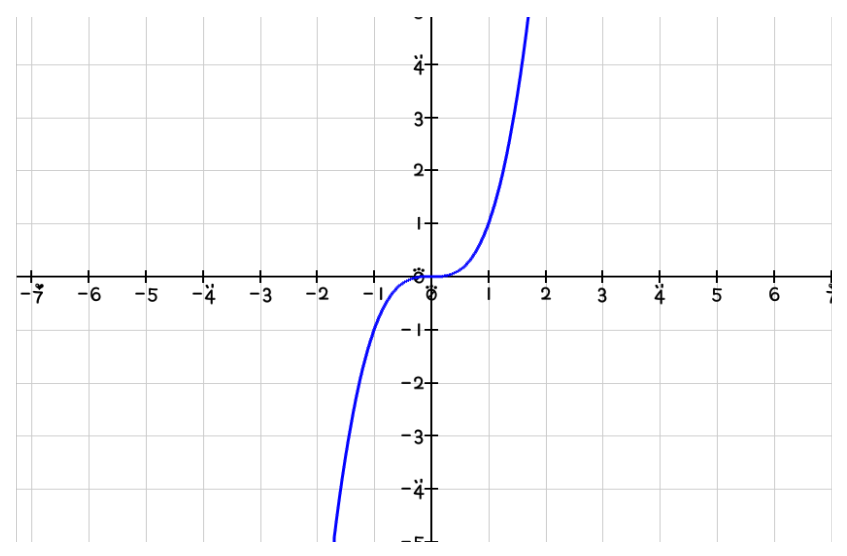

Gambar 4.11. Grafik Fungsi $f(x)=x^{3}$

Turunan pertama dari $f$ adalah $f^{\prime}(x)=3 x^{2}$, dari analisa diperoleh :

$f^{\prime}(x)>0$ jika $-\infty<x<0$

$f^{\prime}(x)>0$ jika $0<x<+\infty$ 
Karena $f$ kontinu di $x=0$ maka

$f$ naik pada $(-\infty, 0]$

$f$ naik pada $[0,+\infty)$

0

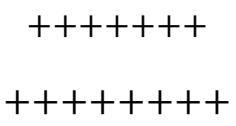

Gambar 4.12. Tanda dari $f^{\prime}(x)$

Gabungan hasil-hasil tersebut menyatakan bahwa $f$ naik pada selang $(-\infty,+\infty)$. Terjadi perubahan di $x=0$, akan tetapi bukan perubahan dari naik ke turun.

\section{KECEKUNGAN FUNGSI}

Misal $f$ dapat diturunkan pada suatu selang

a. $\quad f$ disebut cekung ke atas pada suatu selang jika $f^{\prime}$ naik pada selang tersebut

b. $\quad f$ disebut cekung ke bawah pada suatu selang jika $f^{\prime}$ turun pada selang tersebut 

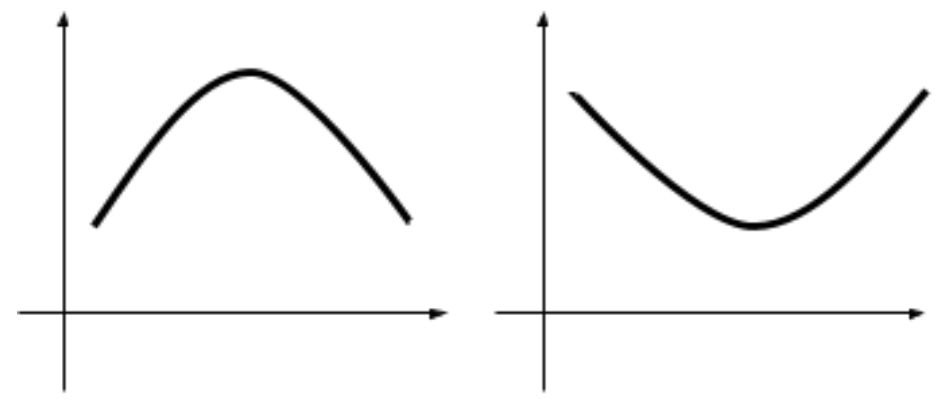

(a)

(b)

Cekung ke bawah

Cekung ke atas

$$
\begin{aligned}
& x \\
& x \\
& y \\
& y
\end{aligned}
$$

\section{Gambar 4.13. Grafik Cekung ke Bawah dan ke Atas}

Pada definisi $f^{\prime}(x)$ diketahui bahwa fungsi dapat berupa fungsi naik atau fungsi turun. Karena $f^{\prime \prime}$ merupakan turunan dari $f^{\prime}$, dimana $f^{\prime}$ naik pada suatu selang terbuka $(a, b)$ jika $f^{\prime \prime}(x)>0$ untuk semua $x$ pada $(a, b)$ dan $f^{\prime}$ turun pada $(a, b)$ jika $f^{\prime \prime}(x)<0$ untuk semua $x$ pada $(a, b)$. Diperoleh definisi sebagai berikut :

Teorema 4.2.1 : 
a. Jika $f^{\prime \prime}(x)>0$ pada suatu selang terbuka $(a, b)$ maka $f$ cekung ke atas pada $(a, b)$

b. Jika $f^{\prime \prime}(x)<0$ pada suatu selang terbuka $(a, b)$ maka $f$ cekung ke bawah pada $(a, b)$

\section{Contoh 4.5 :}

Tentukan selang terbuka yang menyebabkan fungsi-fungsi berikut cekung ke atas dan selang terbuka yang menyebabkan fungsi cekung ke bawah!
a. $f(x)=x^{2}-3 x-4$
b. $f(x)=x^{3}$

\section{Penyelesaian :}

Penyelesaian a.

Perhitungan turunan pertama dan kedua akan diperoleh

$f^{\prime}(x)=2 x-3 \operatorname{dan} f^{\prime \prime}(x)=2$

Karena $f^{\prime \prime}(x)>0$ untuk semua $x$, maka fungsi $f$ cekung ke atas pada $(-\infty,+\infty)$ sesuai Gambar 4.10.

Penyelesaian b.

Perhitungan turunan pertama dan kedua akan diperoleh

$f^{\prime}(x)=3 x^{2} \operatorname{dan} f^{\prime \prime}(x)=6 x$

Karena $f^{\prime \prime}(x)<0$ jika $x<0$ dan $f^{\prime \prime}(x)>0$ jika $x>0$ maka $f$ cekung ke bawah pada $(-\infty, 0)$ dan cekung ke atas pada $(0,+\infty)$ sesuai Gambar 4.11. 


\subsection{NILAI EKSTRIM}

Misalkan $f$ terdefinisi pada selang $I$ yang memuat $c$

1. $f(c)$ merupakan nilai minimum $f$ pada $I$ jika $f(c) \leq f(x)$ untuk semua $x$ dalam $I$.

2. $f(c)$ merupakan nilai maksimum $f$ pada $I$ jika $f(c) \geq f(x)$ untuk semua $x$ dalam $I$.

Nilai minimum dan maksimum suatu fungsi pada selang tertentu disebut sebagai nilai ekstrim suatu fungsi pada selang tersebut. Nilai ekstrim suatu fungsi dapat terjadi pada ujung selang. Nilai ekstrim yang terjadi pada ujung selang disebut nilai ekstrim ujung. Suatu fungsi tidak harus memiliki nilai minimum atau maksimum pada selang tertentu.

\section{Teorema 4.3.1}

Jika $f$ kontinu pada selang tutup $[a, b]$, maka $f$ memiliki nilai minimum dan maksimum pada selang tersebut.

DI MANA TERJADINYA NILAI-NILAI EKSTRIM? Biasanya fungsi yang ingin kita maksimumkan atau minimumkan akan mempunyai suatu selang $I$ sebagai daerah asalnya. Nilai-nilai ekstrim sebuah fungsi yang didefinisikan pada selang tertutup sering kali terjadi pada titik-titik ujung.

\section{Teorema 4.3.2}

(Teorema Titik Kritis). Andaikan $f$ didefinisikan pada selang $I$ yang memuat titik $c$. Jika $f(c)$ adalah titik ekstrim, maka $c$ haruslah suatu titik kritis, yakni $c$ berupa salah satu:

I. titik ujung dari $I$; 

II. $\quad$ titik stasioner dari $f\left(f^{\prime}(c)\right)=0$;
III. titik singular dari $f\left(f^{\prime}(c)\right.$ tidak ada)

\section{Definisi Nilai Ekstrim Lokal}

1. Jika ada selang buka yang memuat $c$ sedemikian sehingga $f(c)$ merupakan nilai maksimum, maka $f(c)$ disebut maksimum local $f$, atau kita dapat menyatakan bahwa $f$ memiliki maksimum local pada $(c, f(c))$.

2. Jika ada selang buka yang memuat $c$ sedemikian sehingga $f(c)$ merupakan nilai minimum, maka $f(c)$ disebut minimum local $f$, atau kita dapat mengatakan bahwa $f$ memiliki minimum local pada $(c, f(c))$.

DI MANA NILAI-NILAI EKSTRIM LOKAL TERJADI? Teorema titik kritis berlaku sebagaimana dinyatakan, dengan ungkapan nilai ekstrim lokal, bukti pada dasarnya sama. (Titik ujung, titik stasioner, dan titik singular) adalah calon untuk titik tempat kemungkinan terjadinya eksstrim lokal.

\section{Toerema 4.3.2.1. (Uji Turunan Pertama untuk Ekstrim Lokal).}

Andaikan $f$ kontinu pada selang terbuka $(a, b)$ yang memuat titik kritis $C$.

I. Jika $f^{\prime}(x)>0$ untuk semua $x$ dalam $(a, c)$ dan $f^{\prime}(x)<0$ untuk semua $x$ dalam $(c, b)$, maka $f(c)$ adalah nilai maksimum lokal $f$.

II. Jika $f^{\prime}(x)<0$ untuk semua $x$ dalam $(a, c)$ dan $f^{\prime}(x)<0$ untuk semua $x$ dalam $(c, b)$, maka $f(c)$ adalah niali minimum local $f$.

III. Jika $f^{\prime}(x)$ bertanda sama pada kedua pihak $c$, maka $f(c)$ bukan nilai ekstrim lokal $f$. 


\section{Teorema 4.3.2.2. (Uji Turunan Kedua Untuk Ekstrim Lokal).}

Andaikan $f^{\prime}$ dan $f^{\prime \prime}$ ada pada setiap titik dalam selang terbuka $(a, b)$ yang memuat $c$, dan andaikan $f^{\prime}(c)=0$
I. Jika $f^{\prime \prime}(c)<0, f(c)$ adalah nilai maksimum lokal $f$.
II. Jika $f(c)>0, f(c)$ adalah nilai minimum lokal $f$.

\subsection{NILAI MAKSIMUM DAN MINIMUM FUNGSI}

Maksimum Lokal dan minimum lokal secara berturut-turut kadang disebut sebagai maksimum relative dan minimum relative.

\section{A. Maksimum dan Minimum fungsi pada Interval tertutup}

Definisi Maksimum dan Minimum Jika $c$ adalah interval tertutup $[a, b]$, maka $f(c)$ dikatakan nilai minimum dari $f(c)$ pada $[a, b]$ jika $f(c) \leq f(x)$ untuk semua $x$ pada $[a, b]$. Jika $d$ dalam interval tertutup $[a, b]$, maka $f(d)$ dikatakan maksimum dari $f(x)$ pada $[a, b]$ Jika $f(x) \leq f(d)$ untuk semua $x$ dalam $[a, b]$.

\section{Teorema 4.3.3.}

Jika $f$ kontinu pada selang tertutup $[a, b]$, maka $f$ mencapai nilai maksimum dan nilai minimum.

\section{Contoh 4.6 :}

Carilah nilai-nilai maksimum dan minimum dari fungsi

$f(x)=x^{2}-4 x$ pada $(-2,0)$ !

\section{Penyelesaian :}

Karena polinomial terdeferensial dimana-mana, maka $f$ terdeferensial pada selang $(-2,0)$. Jadi, jika nilai ekstrim terletak 
pada selang $(-2,0)$ maka nilai tersebut berada pada titik dimana turunannya nol. Karena $f^{\prime}(x)=2 x-4$ dan $f^{\prime}(x)=0$ maka diperoleh

$$
x^{2}-4 x=0
$$

Atau

$$
(x+2)(x-2)=0
$$

Turunan fungsi $f^{\prime}(x)=2 x-4$

Titik kritis $f(x)=2 x-4=0 \quad 2 x=4 \quad x=2$

Titik kritisnya $\{-2,0,2\}$

Untuk $x=-2$ maka $f(-2)=(-2)^{2}-4(-2)=4+8=12$

Untuk $x=0$ maka $f(0)=(0)^{2}-4(0)=0$

Untuk $x=2$ maka $f(2)=(2)^{2}-4(2)=4-8=-4$

Jadi, nilai fungsi maksimum di $f(-2)=12$ dan nilai fungsi minimum di $f(2)=-4$

\section{Contoh 4.7 :}

Carilah titik-titik kritis dari $f(x)=-2 x^{3}+3 x^{2}$ pada $\left[\frac{1}{2}, 2\right]$ serta nilai minimum dan maksimum fungsinya!

\section{Penyelesaian :}

Titik ujung $\quad: \frac{1}{2}$ dan 2

Titik stasioner $: f^{\prime}(x)=0$ 


$$
\begin{aligned}
& -6 x^{2}+6 x=0 \\
& -6 x(x-1)=0 \\
& x=0 \text { dan } x=1
\end{aligned}
$$

Titik ada titik singular

Titik kritis $\quad: \frac{1}{2}, 0,1,2$

Evaluasi $f(x)$ di titik-titik kritis tersebut diperoleh

$$
\begin{gathered}
f\left(\frac{1}{2}\right)=-2\left(\frac{1}{2}\right)^{3}+3\left(\frac{1}{2}\right)^{2}=-2\left(\frac{1}{8}\right)+3\left(\frac{1}{4}\right)=-\frac{2}{8}+\frac{3}{4}=\frac{4}{8}=\frac{1}{2} \\
f(0)=-2(0)^{3}+3(0)^{2}=0 \\
f(1)=-2(1)^{3}+3(1)^{2}=1 \\
f(2)=-2(2)^{3}+3(2)^{2}=-16+12=-4
\end{gathered}
$$

Jadi, nilai minimum -4 terjadi di $x=2$ dan nilai maksimum 1 terjadi di $x=1$.

\section{SOAL LATIHAN}

1. Tentukan nilai-nilai maksimum dan minimum $f$ pada selang tertutup yang diberikan dan nyatakan dimana nilai-nilai itu terjadi.
a. $f(x)=6 x-x^{2} ;[0,4]$
b. $f(x)=2 x^{3}-3 x^{2}-12 x ;[-3,3]$
c. $f(x)=\sin \sin x+\cos ^{2} x ; \quad[-\pi, \pi]$
d. $f(x)=(x-2)^{3} ;[0,4]$
e. $f(x)=\cos \cos x-\sin \sin x ; \quad[0, \pi]$ 
2. Tentukan nilai-nilai maksimum dan minimum $f$ pada selang yang diberikan, jika ada.
a. $f(x)=2 x^{3}-3 x^{4} ;(-\infty,+\infty)$
b. $f(x)=1-\frac{1}{x} ;(0,+\infty)$
c. $f(x)=\frac{2 x}{x^{2}+1} ; \quad(0,+\infty)$

3. Tentukan nilai maksimum dan minimum dari

$$
f(x)=\{4 x-2(x-2)(x-3) x<1 x \geq 1
$$

Pada $\left[\frac{1}{2}, \frac{7}{2}\right]$.

Note : Gunakan fungsi sesuai dengan batasan yang diketahui.

\subsection{APLIKASI MASALAH MAKSIMUM \& MINIMUM}

Aplikasi masalah maksimum dan minimum dapat dikelompokkan dalam dua kategori yaitu

a. Masalah-masalah yang termasuk kedalam masalah maksimum dan minimum pada selang tertutup berhingga,

b. Masalah-masalah maksimum atau minimum suatu fungsi kontinu pada selang tak berhingga yang tidak tertutup.

Untuk masalah pada kategori pertama dimana kita ingin memaksimumkan atau meminimumkan suatu fungsi yang berada pada selang tertutup.

\section{MASALAH-MASALAH YANG TERKAIT DENGAN SELANG TERTUTUP BERHINGGA}

Langkah-langkah yang harus dilakukan apabila menemukan persoalan yang berkaitan dengan aplikasi masalah maksimum atau minimum dengan selang tertutup berhingga antara lain : 
1. Buatlah definisi, inisiasi atau permisalan untuk setiap variabel yang diketahui pada soal

2. Buatlah suatu gambar untuk masalah yang ada pada persoalan dengan memberikan variabel-varibel yang telah didefinisikan.

3. Menentukan hubungan antar variabel, sehingga dapat dibentuk suatu fungsi pada persoalan yang diberikan.

4. Tuliskan rumus untuk besaran yang harus dimaksimumkan atau diminimumkan dalam bentuk variabel-variabel yang telah didefinisikan.

5. Gunakan kondisi-kondisi pada masalah yang ada dan nyatakan dalam satu variabel, misalnya $x$ atau $y$

6. Tentukan himpunan nilai-nilai $x$ yang mungkin, biasanya berupa suatu selang

7. Tentukan titik-titik kritis yaitu titik ujung, titik stationer, titik singular, dengan menghitung turunan dari fungsi $f$

8. Gunakan titik-titik kritis yang telah dihitung untuk menentukan titik kritis mana yang memberikan nilai maksimum dan minimum.

\section{Contoh 4.8 :}

Sebuah kotak kardus makanan dibuat dari selembar kertas karton yang berukuran $10 \mathrm{~cm} \times 20 \mathrm{~cm}$ dengan menggunting ke empat sudutnya sehingga membentu bujur sangkar yang berukuran sama dan melipatnya ke sisi bagian atas. Berapa ukuran bujur sangkar agar dapat diperoleh kotak dengan isi terbesar?

\section{Penyelesaian :}

Dimisalkan :

$x \quad=$ panjang $($ dalam $\mathrm{cm}$ ) sisi bujur sangkar yang digunting

$V \quad=$ isi (dalam $\mathrm{cm}^{3}$ ) kotak kardus yang dihasilkan 
Sketsa Gambar :
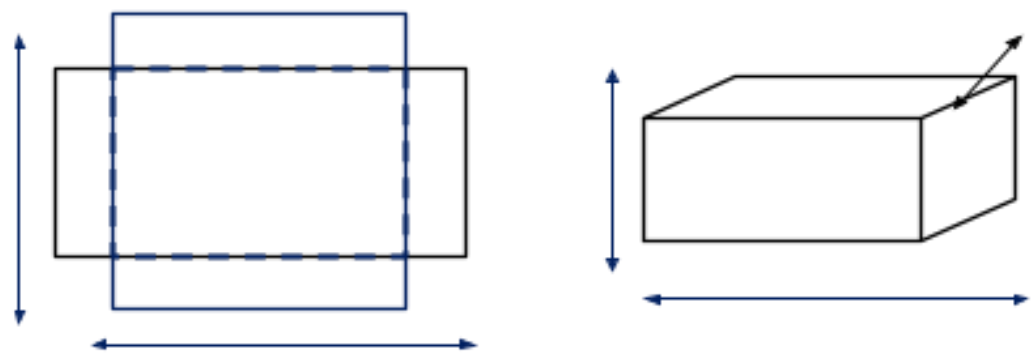

$20 \mathrm{~cm}$

X

X

X

X

X

X

X

X

$10 \mathrm{~cm}$

$20-2 x$

$10-2 x$

(a)

(b)

$\mathrm{X}$

Gambar 4.14. Bujur Sangkar yang dipotong sebanyak $x$ 
Karena bujur sangkar bersisi $x$ dibuang dari masing-masing sudut, kotak yang dihasilkan mempunyai ukuran $(10-2 x)(20-2 x) \mathrm{x}$ (Gambar 4.14. (b)), maka diperoleh

$$
V=(10-2 x)(20-2 x) x=200 x-60 x^{2}+4 x^{3}
$$

Dalam hal ini $x$ mempunyai batasan, yang artinya $x$ adalah suatu nilai potong (dalam hal ini kedalaman atau tinggi), sehingga nilai $x$ tidak bisa negatif. Dan ukuran pemotongannya pun tidak boleh lebih dari setengah dari lebarnya, sehingga peubah $x$ dalam (4.5.1) mempunyai batasan sebagai berikut

$$
0 \leq x \leq 5
$$

Karena sisi kanan pada (4.5.1) polinomial dalam $x$ yang kontinu pada selang tertutup $[0,5]$, dan akibatnya dapat digunakan metode pasa sub bab sebelumnya untuk menemukan nilai maksimum.

$$
\frac{d V}{d x}=200-120 x+12 x^{2}=4\left(50-30 x+3 x^{2}\right)
$$

Dengan $\frac{d V}{d x}=0$, sehingga diperoleh

$$
\left(50-30 x+3 x^{2}\right)=0
$$

Yang dapat diselesaikan dengan menemukan akar-akarnya dengan rumus abc sebagai berikut :

$$
x_{1,2}=30 \pm \frac{\sqrt{(-30)^{2}-4(3)(50)}}{2(3)}=30 \pm 25.98
$$

Didapatkan nilai akar yaitu $x_{1}=4$ dan $x_{2}=50,98$, karena $x=50,98$ diluar selang $[0,5]$ maka nilai maksimum $V$ hanya terjadi di $x=4$ atau salah satu titik $x=0, x=5$. Substitusi nilai $x$ tersebut pada (4.5.1) menghasilkan 


$$
\begin{gathered}
V(0)=200(0)-60(0)+4(0)=0 \\
V(4)=200(4)-60(4)^{2}+4(4)^{3}=96 \\
V(5)=200(5)-60(5)^{2}+4(5)^{3}=0
\end{gathered}
$$

Dengan melihat nilai diatas, isi $V$ terbesar adalah $V=96 \mathrm{~cm}^{3}$ dengan memotong bujur sangkar pada sisi $x=4 \mathrm{~cm}$.

\section{Contoh 4.9 :}

Apabila ada sebuah silinder yang berada didalam suatu kerucut dengan jari-jari kerucut $7 \mathrm{~cm}$ dan tinggi $14 \mathrm{~cm}$. Tentukan volume silinder terbesar yang didapat dari memksimalkan ukuran kerucut yang dapat ditempati oleh silinder!

\section{Penyelesaian :}

Dimisalkan :

$r \quad$ = jari-jari (dalam $\mathrm{cm}$ ) silinder

$h \quad=$ tinggi $($ dalam $\mathrm{cm})$ silinder

$V \quad=$ volume $\left(\right.$ dalam $\left.\mathrm{cm}^{3}\right)$ silinder

Rumus untuk Volume silinder adalah

$$
V=\pi r^{2} h
$$

Agar variabel pada rumus menjadi satu variabel, maka diperlukan hubungan antara $r$ dan $h$. Dengan menggunakan perbandingan pada Gambar 4.15 (b) diperoleh

$$
\begin{aligned}
& \frac{14-h}{r}=\frac{14}{7} \text { atau } \\
& h=14-2 r
\end{aligned}
$$



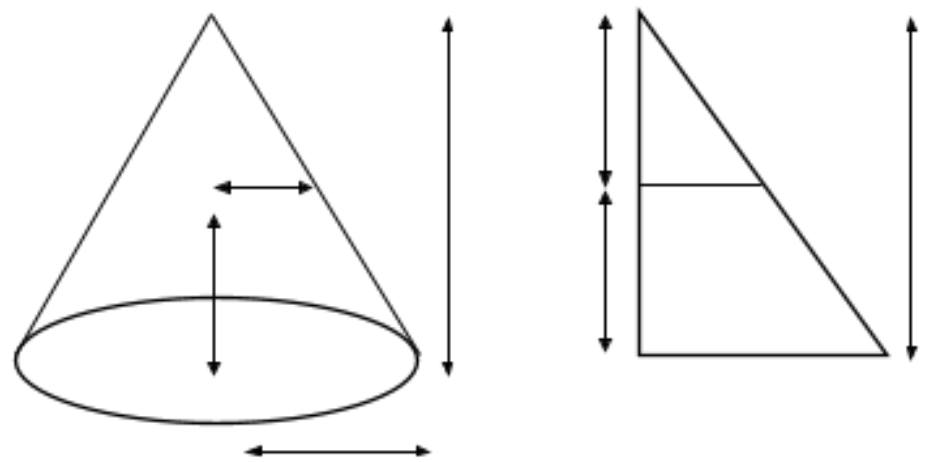

$14 \mathrm{~cm}$

$7 \mathrm{~cm}$

h

$\mathrm{r}$

$\mathrm{h}$

14-h

$14 \mathrm{~cm}$

(a)

(b)

Gambar 4.15. Silinder didalam Kerucut

Substitusi persamaan (4.5.3) kedalam persamaan (4.5.2) diperoleh :

$V=\pi r^{2}(14-2 r)=14 \pi r^{2}-2 \pi r^{3}$

Yang menyatakan $V$ dalam $r$. Karena $r$ adalah jari-jari, jelas $r$ tidak boleh negatif, sehingga variabel $r$ harus memenuhi 


\section{$0 \leq r \leq 7$}

Agar nilai $V$ menjadi maksimum. Dengan metode-metode yang telah dipelajari sebelumnya, maka nilai maksimum diperoleh jika

$$
\frac{d V}{d r}=28 \pi r-8 \pi r^{2}=4 \pi r(7-2 r)=0
$$

Sehingga didapatkan

$$
4 \pi r(7-2 r)=0
$$

Nilai $r=7 / 2$. Karena nilai ini berada pada selang [0,7], maka nilai maksimum terjadi di salah satu titik sebagai berikut :

$$
r=0, r=\frac{7}{2}, r=7
$$

Substitusi nilai $r$ pada persamaan (4.5.4) menghasilkan nilai sebagai berikut :

$$
\begin{gathered}
r=0 \rightarrow V=14 \pi r^{2}-2 \pi r^{3}=14 \pi(0)-2 \pi(0)=0 \\
r=\frac{7}{2} \rightarrow V=14 \pi r^{2}-2 \pi r^{3}=14 \pi\left(\frac{7}{2}\right)^{2}-2 \pi\left(\frac{7}{2}\right)^{3}=85.75 \\
r=7 \rightarrow V=14 \pi r^{2}-2 \pi r^{3}=14 \pi(7)^{2}-2 \pi(7)^{3}=0
\end{gathered}
$$

Dengan demikian Volume maksimumnya adalah 85,75 terjadi jika $r=\frac{7}{2}$, dan ukuran ketinggian silinder yang diperlukan adalah

$$
h=14-2 r=14-2\left(\frac{7}{2}\right)=7
$$

Note : Melihat persoalan ini, apabila ketinggian kerucut merupakan 2 kali dari jari-jarinya, maka ukuran maksimal suatu benda didalam kerucut yang diperlukan agar volume menjadi maksimal adalah setengah dari ukuran kerucut itu sendiri. 
Aplikasi masalah maksimum dan minimum, yang mana kita ingin memaksimumkan atau meminimumkan suatu fungsi berupa selang tertutup dapat kita selesaikan. Tetapi, selang-selang yang muncul tidak selalu tertutup. Terkadang terbuka atau bahkan setengah terbuka dan setengah tetutup. Kita akan menangani aplikasi masalah ini jika kita menerapkan langkah-langkahnya secara benar pada sub bab selanjutnya.

\section{MASALAH-MASALAH YANG TERKAIT DENGAN SELANG YANG TIDAK BERHINGGA ATAU SELANG BERHINGGA YANG TIDAK TERTUTUP}

\section{Contoh 4.10 :}

Apabila kaleng berbentuk silinder diisi dengan cairan pembersih sebanyak 1 It $\left(1000 \mathrm{~cm}^{3}\right)$ cairan. Berapa tinggi dan jari-jari yang dipilih untuk meminimumkan banyaknya bahan yang diperlukan untuk pembuatannya?

\section{Penyelesaian :}

Dimisalkan :

$h \quad=$ tinggi $($ dalam $\mathrm{cm})$ kaleng

$r \quad=$ jari-jari (dalam $\mathrm{cm}$ ) kaleng

$S \quad=$ luas permukaan (dalam $\mathrm{cm}^{2}$ ) kaleng

Kaleng berupa silinder dapat terdiri dari dua lempengan bulat berbentuk lingkaran dengan jari-jari $r$ dan sebuah empat persegi 
panjang dengan ukuran $h$ kali $2 \pi r$. Dengan demikian luas permukaan kaleng menjadi

$S=2 \pi r^{2}+2 \pi r h$

Eliminasi salah satu variabel pada (4.5.5) sehingga $S$ dinyatakan sebagai persamaan yang mengandung satu variabel. Karena isi kaleng $1000 \mathrm{~cm}^{3}$, dengan rumus silinder yaitu $V=\pi r^{2} h$ untuk isi tabung diperoleh

$$
1000=\pi r^{2} h
$$

$h=\frac{1000}{\pi r^{2}}$

Substitusi (4.5.6) kedalam persamaan (4.5.5), sehingga menghasilkan

$S=2 \pi r^{2}+2 \pi r\left(\frac{1000}{\pi r^{2}}\right)=2 \pi r^{2}+\frac{2000}{r}$

Karena jari-jari harus positif, masalah ini direduksi dengan menentukan nilai $r$ pada $(0,+\infty)$ yang menyebabkan (4.5.7) minimum. Oleh karena $S$ merupakan fungsi kontinu dari $r$ pada $(0,+\infty)$ dengan

$$
\frac{d S}{d r}=4 \pi r-\frac{2000}{r^{2}}
$$

Dengan $\frac{d S}{d r}=0$, maka diperoleh

$$
4 \pi r-\frac{2000}{r^{2}}=0 \rightarrow r=\frac{10}{\sqrt[3]{2 \pi}}
$$


Karena $r$ pada (4.5.8) merupakan satu-satunya titik kritis pada selang $(0,+\infty)$, nilai $r$ menghasilkan nilai minimum $S$. Dari nilai $h$ yang berhubungan ke $r$ ini adalah

$$
h=\frac{1000}{\pi(10 / \sqrt[3]{2 \pi})^{2}}=2 r
$$

bukan kebetulan bahwa tinggi kaleng sama dengan diameter dari dasarnya, yaitu sekitar $r=\frac{10}{\sqrt[3]{2 \pi}} \approx 5,4$. Atau cara lain dapat menggunakan uji turunan kedua dari $S$, dengan catatan bahwa nilainya positif unutk $r>0$ dan $r=\frac{10}{\sqrt[3]{2 \pi}} \mathrm{cm}$.

\section{SOAL LATIHAN}

1. Alkohol dibuat oleh perusahaan farmasi dan dijual borongan dengan harga Rp 200 per unit (takaran botol). Jika total produksi untuk $x$ unit adalah

$$
C(x)=5.000 .000+80 x+0.003 x^{2}
$$

Dan jika kapasitas produksi terbesar dari perusahaan 30.000 unit dalam suatu waktu tertentu. Berapa banyak unit alkohol yang harus diproduksi dan dijual agar memperoleh keuntungan yang maksimal?

2. Segiempat mempunyai dua sudut bawah pada sumbu $x$ dan dua sudut atas pada kurva $y=4-x^{2}$. Berapa ukuran segiempat dengan luas terbesar?

3. Suatu segiempat dilukiskan dalam segitiga yang mempunyai sisi saling tegak lurus dengan panjang $6 \mathrm{~cm}$ dan $10 \mathrm{~cm}$. Tentukan ukuran dari segiempat tersebut agar diperoleh luas 
terbesar dengan asumsi bahwa segitiga diposisikan seperti pada Gambar 4.16.
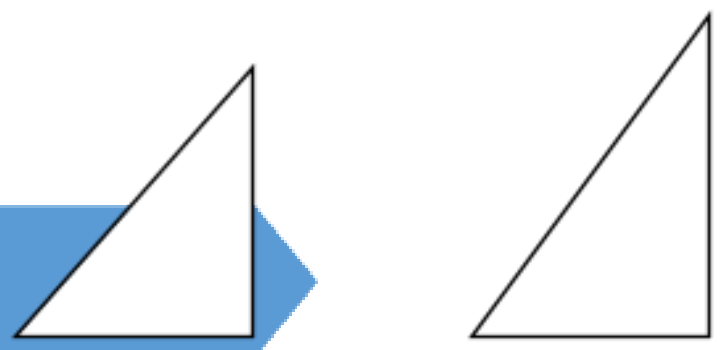

$6 \mathrm{~cm}$

$8 \mathrm{~cm}$

$6 \mathrm{~cm}$

$10 \mathrm{~cm}$

(a)

(b)

Gambar 4.16. Segitiga

\section{BAB 5 :}

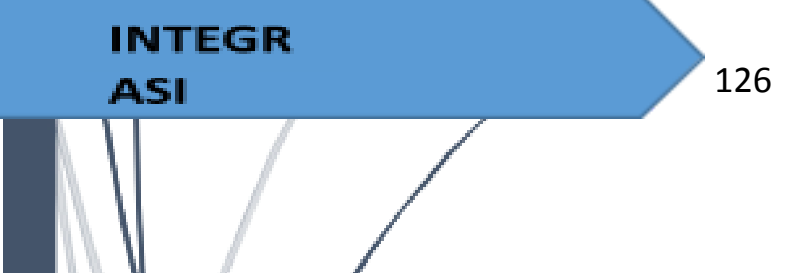


Capaian Pembelajaran Mata Kuliah :

- Mahasiswa

mampu

memahami

dan

menyelesaikan persoalan

yang berkaitan dengan

integral tak tentu

- Mahasiswa

menerapkan

dapat

integral dalam kaitannya

dengan

permasalahan

teknik.

Dalam bab ini dibahas mengenai Kalkulus Integral beserta sifat-sifatnya dan proses perhitungannya secara luas. Pada dasarnya konsep integral sebagai kebalikan dari operasi differensial yaitu merupakan bentuk umum dari operasi antiturunan. Dan integral dapat pula diilustrasikan sebagai bentuk limit jumlahan Riemann yang merupakan pendekatan dari proses perhitungan luas pada masing-masing sub luasan.

\subsection{KONSEP DASAR INTEGRAL}


Turunan atau differensial adalah materi kalkulus yang banyak sekali diterapkan dalam bidang teknik dan ekonomi. Oleh karena itu, integral invers atau kebalikan dari turunan juga menjadi bagian yang tak kalah pentingnya. Penerapannya di bidang teknik dan ekonomi tidak dapat dipungkiri. Di bidang teknik, integral digunakan untuk menghitung luas bidang datar dan volume benda putar. Dan tentunya integral sangat berguna di kehidupan sehari-hari, misalnya banyak ditemui di bidang-bidang yang tidak teratur yang tidak dapat dihitung menggunakan rumus yang sudah dikenal sebelumnya, seperti luas persegi, segitiga, lingkaran dan sebagainya. Pada konsep dasar integral ini, dibahas mengenai integral dengan pendekatan luas oleh suatu kurva lengkung.

Fungsi $F$ disebut sebagai anti turunan dan anti differensial atau integral dari fungsi $f$ pada selang $I$, jika berlaku $F(x)=f(x)$ untuk setiap $x$ di $I$.

Jika $f$ suatu turunan dari $F$, maka notasinya adalah $F^{\prime}(x)=f(x)$ atau dapat juga dituliskan sebagai $d F(x)=f(x) d x$. Sebaliknya, $F$ adalah anti turunan dari $f$ dan notasi atau simbol untuk operasi pengintegralannya adalah $\int$. Kita dapat menuliskan sebagai

$$
\int f(x) d x=F(x)+C
$$

\section{Dengan}

- $F(x)$ adalah fungsi integral umum yang bersifat $F^{\prime}(x)=f(x)$

- $f(x)$ disebut fungsi integral

- $C$ adalah konstanta real sembarang

\section{MASALAH LUAS}


Dalam bagian ini diberikan pengertian mengenai luas yang akan ditunjukkan dengan cara menghitung luas menggunakan limit dan dikembangkan dengan menggunakan definisi luas dibawah kurva tertentu. Diberikan fungsi $f$ yang kontinu tak negatif pada selang $[a, b]$, tentukan luas antara grafik yang dibatasi oleh fungsi $f$ dan selang $[a, b]$, pada sumbu $x$ seperti ditunjukkan pada Gambar 5.1.

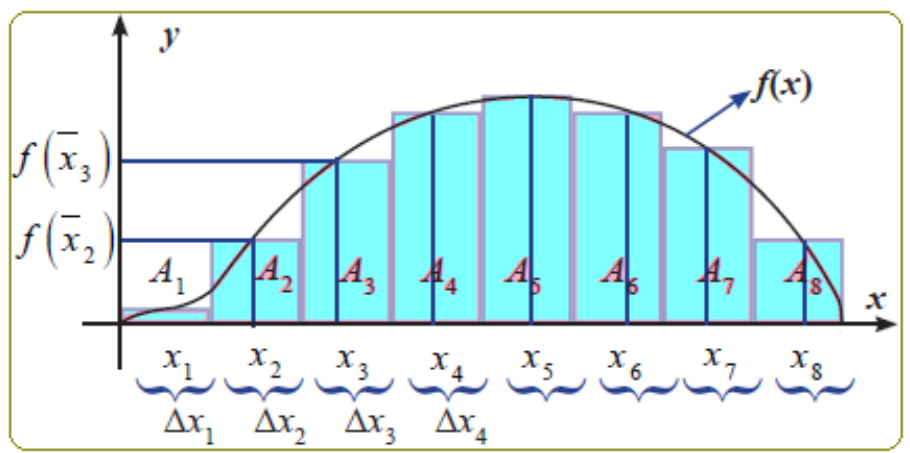

Gambar 5.1. Luas Dalam Pendekatan (limit) fungsi

Pada Gambar 5.1. diatas menunjukkan bahwa luas daerah yang dibatasi dari $x=p$ sampai $x=q$, sedangkan bagian atas dibatasi oleh kurva $v=f(x)$, dengan $f$ kontinu dan tak negatif pada $[p, q]$.

\section{DEFINISI LUAS}

Teorema 5.1.1. jika suatu fungsi $f$ kontinu pada $[p, q]$, dan jika $f(x) \geq 0$ untuk semua $x$ pada $[p, q]$, maka luas dibawah kurva $y=f(x)$ sepanjang selang $[p, q]$ didefinisikan sebagai

$$
L=\sum_{k=1}^{n} f\left(x_{k}^{*}\right) \Delta x_{k}
$$

Jadi integral $f(x)$ pada selang $[a, b]$ adalah luas di atas selang $[a, b]$, tetapi dibawah $y=f(x)$ dikurangi luas dibawah $[a, b]$ tetapi diatas $y=f(x)$ sehingga dapat didefiniskan dengan Gambar 5.2. berikut ini, dengan $S$ sebagai daerah yang ditanyakan luas daerahnya. 


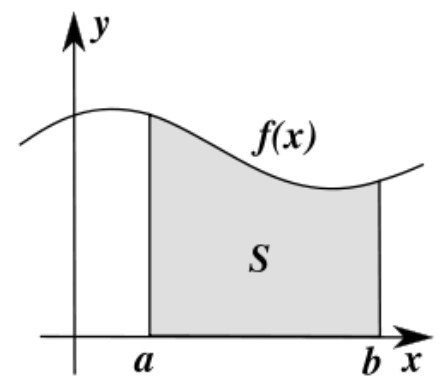

Gambar 5.2. Luas Kurva Dalam Selang $[a, b]$

Teorema 5.1.2. Jika fungsi $f$ kontinu dalam selang $[a, b]$ yang bernilai positif, dan negatif, maka nilai integral tertentu dari $y=f(x)$ pada selang $[a, b]$ didefinisikan sebagai

$$
\int_{a}^{b} f(x) d x=\sum_{k=1}^{n} f\left(x_{k}^{*}\right) \Delta x_{k}
$$

\section{Contoh 5.1.}

Hitunglah $\int_{2}^{4}(1-x) d x$

\section{Penyelesaian :}

Integrannya negatif sepanjang selang $[2,4]$, sehingga integral tersebut merupakan negatif dari luas trapesium yang di arsir pada gambar berikut ini. Luas Trapesium tersebut adalah 4, sehingga 


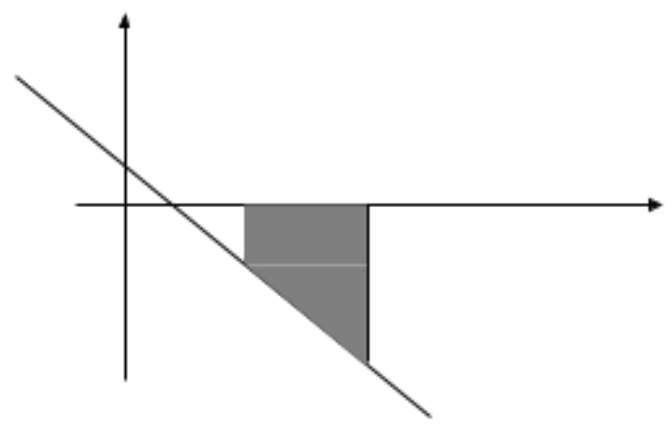

$\mathbf{X}$

$\mathbf{y}$

2

4

$$
y=1-x
$$

Gambar 5.3. Luas Trapesium

\subsection{INTEGRAL TAK TENTU}

Integral atau anti diferensial merupakan operasi invers atau kebalikan dari diferensial atau turunan. Oleh karena itu, rumus-rumus integral dapat diturunkan dari rumus-rumus turunan. Berikut merupakan rumus dasar integral tak tentu fungsi aljabar.

1. $\int x^{n} d x=\frac{1}{n+1} x^{n+1}+C$

\section{Contoh 5.2. :}

Dapatkan integral pada fungsi $f(x)=x^{5}$ 
Penyelesaian :

$$
f(x)=\int x^{5} d x=\frac{1}{6} x^{6}+C
$$

2. $\int k x^{n} d x=\frac{k}{n+1} x^{n+1}+C, \mathrm{k}=$ konstanta tertentu

\section{Contoh 5.3. :}

Dapatkan integral pada fungsi $f(x)=3 x^{10}$.

\section{Penyelesaian :}

$$
f(x)=\int 3 x^{10} d x=3 \int x^{10} d x=\frac{3(1)}{11} x^{11}=\frac{3}{11} x^{11}+C
$$

3. $\int d x=x+C$

Contoh 5.4. :

Dapatkan integral pada fungsi $f(x)=-2$

Penyelesaian :

$$
f(x)=\int-2 d x=-2 x+C
$$

4. $\int k d x=k x+C$

$\int k f(x) d x=k \int f(x) d x=k F(x)+C$

\section{Contoh 5.5. :}

Dapatkan anti turunan dari fungsi $-\frac{1}{100}$

Penyelesaian :

$$
\int-\frac{1}{100} d x=-\frac{1}{100} x+C
$$


5. $\int f(x)+g(x) d x=\int f(x) d x+\int g(x) d x=F(x)+G(x)+C$

\section{Contoh 5.6. :}

Dapatkan anti turunan dari $x^{2}+2 x+1$

Penyelesaian :

$$
\int x^{2}+2 x+1 d x=\frac{1}{3} x^{3}+\frac{2}{2} x^{2}+x=\frac{x^{3}}{3}+x^{2}+x+C
$$

6. $\int f(x)-g(x) d x=\int f(x) d x-\int g(x) d x=F(x)-G(x)+C$

\section{Contoh 5.7. :}

Dapatkan integral dari fungsi $x^{3}-3 x^{2}-3 x-1$

Penyelesaian :

$$
\int x^{3}-3 x^{2}-3 x-1 d x=\frac{1}{3} x^{3}-\frac{3}{3} x^{3}-\frac{3}{2} x^{2}+C
$$

7. $\int \frac{1}{x} d x=\ln \ln |x|+C$

\section{Contoh 5.8. :}

Dapatkan penyelesaian integral pada fungsi berikut $-5 / x$

Penyelesaian : $\int-\frac{5}{x} d x=-5 \ln \ln x+C$

8. (Integral Sebagian / By Part)

Jika $f$ dan $g$ adalah fungsi fungsi yang terdeferensial, maka dengan aturan perkalian diperoleh

$$
\frac{d}{d x}[f(x) g(x)]=f(x) g^{\prime}(x)+g(x) f^{\prime}(x)
$$

Dengan mengintegralkan kedua ruas, diperoleh 


$$
\int \frac{d}{d x}[f(x) g(x)] d x=\int f(x) g^{\prime}(x) d x+\int g(x) f^{\prime}(x) d x
$$

Atau

$$
f(x) g(x)+C=\int f(x) g^{\prime}(x) d x+\int g(x) f^{\prime}(x) d x
$$

Atau

$$
\int f(x) g^{\prime}(x) d x=f(x) g(x)-\int g(x) f^{\prime}(x) d x+C
$$

Karena integral ruas kanan menghasilkan suatu konstanta integrasi lain, maka tidak perlu menambah konstanta $C$ dalam persamaan terakhir sehingga diperoleh :

$$
\int f(x) g^{\prime}(x) d x=f(x) g(x)-\int f^{\prime}(x) g(x) d x
$$

Rumus diatas merupakan rumus integrasi sebagian/by part atau integral parsial. Untuk menyederhanakan penulisan, dengan pengambilan

$$
\begin{array}{ll}
u=f(x), & d u=f^{\prime}(x) d x \\
v=g(x), & d v=g^{\prime}(x) d x
\end{array}
$$

Diperoleh bentuk alternatif persamaan sebagai berikut :

$$
\int u d v=u v-\int v d u
$$

\section{Contoh 5.9 :}

Selesaikan $\int x e^{x} d x$

\section{Penyelesaian :}


Untuk menerapkan integrasi parsial atau sebagian, persoalan integrasi pada kasus ini harus ditulis dengan

$$
\int u d v
$$

Salah satu cara untuk menyelesaikan masalah ini adalah dengan mengambil

$u=x$ dan $d v=e^{x} d x$

Sehingga

$d u=d x \operatorname{dan} v=\int d v=\int e^{x} d x=e^{x}$

Jadi berdasarkan rumus diatas diperoleh

$$
\int x e^{x} d x=x e^{x}-\int e^{x} d x=x e^{x}-e^{x}+C
$$

9. Integral Trigonometri

a. $\int \cos \cos x d x=\sin \sin x+C$

b. $\int \sin \sin x d x=-\cos \cos x+C$

c. $\int \sec ^{2} x d x=\tan \tan x+C$

d. $\int \operatorname{cosec}^{2} x d x=x+C$

e. $\int \tan \tan x \sec \sec x d x=\sec \sec x+C$

f. $\int \cot \cot x x d x=x+C$ 


\section{Contoh 5.10 :}

Tentukan integral tak tentu berikut :

a. $\int 2 \cos \cos x-3 \sin \sin x d x$

b. $\int 2 \sec ^{2} x-5 \tan \tan x \sec \sec x d x$

\section{Penyelesaian :}

Penyelesaian (a)

$\int 2 \cos \cos x-3 \sin \sin x d x=2 \int \cos \cos x d x-3 \int \sin \sin x d x=2 \sin$

Penyelesaian (b)

$\int 2 \sec ^{2} x-5 \tan \tan x \sec \sec x d x=2 \int \sec ^{2} x d x-5 \int \tan \tan x \sec \sec$

10. Integrasi Fungsi Rasional dan Pecahan Parsial

Sebagaimana telah diketahui bahwa fungsi rasional adalah hasil bagi polinomial. Pada umumnya, fungsi rasional sukar untuk di integralkan. Pada sub bab ini diberikan suatu metode untuk menyajikan fungsi rasional sebagai jumlahan fungsi rasional sederhana yang dapat di integrasikan dengan metode yang telah dipelajari sebelumnya.

\section{PECAHAN PARSIAL}


Sebagai ilustrasi, sebelum sampai pada pokok pembahasan, terlebih dahulu perlu diperhatikan fungsi berikut :

$$
\frac{2}{x-4}+\frac{3}{x+1}=\frac{2(x+1)+3(x-4)}{(x-4)(x+1)}=\frac{5 x-10}{x^{2}-3 x-4}
$$

Terlihat bahwa sisi sebelah kiri lebih mudah untuk diintegralkan daripada sisi sebelah kanan.

$$
\begin{gathered}
\int \frac{5 x-10}{x^{2}-3 x-4} d x=\int \frac{2}{x-4}+\frac{3}{x+1} d x=\int \frac{2}{x-4} d x+\int \frac{3}{x+1} d x \\
=2 \ln \ln |x-4|+3 \ln \ln |x+1|+C
\end{gathered}
$$

Jadi untuk menyelesaikan integral pecahan parsial diperlukan suatu metode untuk mendapatkan sisi kiri, jika sisi sebelah kanan sudah diketahui. Untuk itu faktorkan penyebutnya pada sisi kanan dan diasumsikan ada konstanta yang tidak diketahui misal A dan B sedemikian hingga

$$
\frac{5 x-10}{x^{2}-3 x-4}=\frac{A}{x-4}+\frac{B}{x+1}
$$

Untuk mendapatkan konstanta A dan B, pertama kalikan dengan $(x-4)(x+1)$ untuk menghilangkan penyebut.

$$
5 x-10=A(x-1)+B(x-4)
$$

Dengan metode substitusi diperoleh $A=2$ dan $B=3$.

Metode alternatif untuk mendapatkan $A$ dan $B$ dilakukan untuk menghasilkan sisi kanan dan $x$ dengan pangkat yang sama dikumpulkan sehingga diperoleh :

$$
\begin{gathered}
A+B=5 \\
A-4 B=-10
\end{gathered}
$$

Dengan eliminasi atau subsitusi persamaan di atas sehingga diperoleh nilai $A=2$ dan $B=3$. 
Suatu teorema dalam aljabar lanjutan menyatakan bahwa setiap fungsi rasional $P(x) / Q(x)$ dengan derajat pembilang lebih kecil dari pada derajat penyebut dapat dinyatakan dengan

$$
\frac{P(x)}{Q(x)}=F_{1}(x)+F_{2}(x)+\ldots+F_{n}(x)
$$

Dengan $F_{1}(x)+F_{2}(x)+\ldots+F_{n}(x)$ fungsi fungsi Rasional dalam bentuk

$$
\frac{A_{1}}{(a x+b)^{k}}
$$

Atau

$$
\frac{A x+B}{\left(a x^{2}+b x+c\right)^{k}}
$$

Dengan $a, b, c \in R, k=1,2,3, \ldots$

Suku suku $F_{1}(x)+F_{2}(x)+\ldots+F_{n}(x)$ pada sisi kanan persamaan pertama disebut pecahan parsial dan semua sisi kanan disebut dekomposisi pecahan parsial dari sisi kiri.

\section{Contoh 5.11 :}

Tuliskan bentuk dekomposisi pecahan parsial dan selesaikan integralnya!

$$
\int \frac{x}{x^{2}-5 x+4} d x
$$

\section{Penyelesaian :}

Integran diatas dapat ditulis kembali sebagai

$$
\frac{x}{x^{2}-5 x+4}=\frac{x}{(x-4)(x-1)}
$$

Sehingga bentuk dekomposisi pecahan parsialnya adalah

$$
\frac{x}{x^{2}-5 x+4}=\frac{A}{(x-4)}+\frac{B}{(x-1)}
$$


Kalikan silang antara pembilang dan penyebut dari bentuk yang telah didekomposisi menjadi

$$
\begin{gathered}
x=A(x-1)+B(x-4) \\
x=A x-A+B x-4 B
\end{gathered}
$$

Masing-masing kelompokkan sesuai dengan variabel dan yang tidak ada variabelnya menjadi

$$
x=(A+B) x+(-A-4 B)
$$

Untuk menentukan nilai $A$ dan $B$, menyamakan nilai konstanta disisi sebelah kiri dan sisi sebelah kanan, dengan demikian menjadi $(A+B)=1$ dan $(-A-4 B)=0$

Dengan eliminasi dan substitusi diperoleh

$$
A=\frac{4}{3}, B=-\frac{1}{3}
$$

Masukkan ke soal kembali pada persamaan (5.11.1) menjadi

$$
\frac{x}{x^{2}-5 x+4}=\frac{4 / 3}{(x-4)}-\frac{1 / 3}{(x-1)}
$$

Dengan mengintegralkan fungsi menjadi

$$
\int \frac{x}{x^{2}-5 x+4} d x=\int \frac{4 / 3}{(x-4)}-\frac{1 / 3}{(x-1)} d x=\frac{4}{3} \int \frac{1}{(x-4)} d x-\frac{1}{3} \int \frac{1}{x-1} d x=\frac{4}{3} \ln \ln (
$$

\section{Note :}

Pengurangan fungsi $\ln \ln x$ sama dengan pembagian fungsinya, sedangkan penjumlahan fungsi $\ln \ln x$ sama dengan perkalian fungsinya.

\section{SOAL LATIHAN}

1. Hitunglah integralnya dan periksalah hasilnya dengan mencari turunan dari jawaban yang diperoleh! 

a. $\int \frac{1}{x^{5}} d x$
b. $\int \frac{5}{t^{\frac{3}{2}}} d t$
c. $\int \sqrt[3]{x^{2} d x}$
d. $\int x^{2}\left(1+x^{2}\right) d x$
e. $\int\left(2-y^{2}\right)^{2} d x$ f. $\int \frac{1-2 t^{3}}{t^{3}} d t$
g. $\int\left(1+x^{2}\right)^{2 / 3} d x$
h. $\int \frac{1}{t^{2}}-\cos \cos t$ i. $\int x^{1 / 3}\left(2-x^{2 / 3}\right) d x$

2. Dapatkan turunannya dan nyatakanlah rumus integrasi yang bersesuaian!
j. $\frac{d}{d x}\left[\sqrt{x^{2}+5}\right]$
k. $\frac{d}{d x}\left[\frac{x}{x^{2}+3}\right]$
I. $\frac{d}{d x}[\sin \sin x-x \cos$

3. Tentukan fungsi $f$ sedemikian hingga $f^{\prime \prime}(x)=x+\cos \cos x$ dan $f(0)=1, f^{\prime \prime}(0)=2$. (petunjuk : integrasikan kedua sisi dua kali)

4. Tuliskan bentuk dekomposisi pecahan parsial (tanpa harus menentukan nilai numerik dari koefisien)
a. $\frac{4 x-1}{(x-3)(x+2)}$
b. $\frac{1-3 x^{2}}{x^{3}\left(x^{2}+4\right)}$
C. $\frac{x+2}{x^{2}(x+2)}$
$d \frac{1-3 \theta^{4}}{(\theta-2)\left(\theta^{2}+1\right)^{3}}$
$e \frac{2 t^{3}-t}{\left(t^{2}+5\right)^{2}}$
$f \frac{2 t^{3}-t^{2}+t-3}{t(t-1)(t-2)^{2}}$

5. Selesaikan integral berikut :
a. $\int \frac{4 x-1}{(x-3)(x+2)} d x$
b. $\int \frac{1-3 x^{2}}{x^{3}\left(x^{2}+4\right)} d x$
C. $\int \frac{x+2}{x^{2}(x+2)} d x$ 

d $\int \frac{1-3 \theta^{4}}{(\theta-2)\left(\theta^{2}+1\right)^{3}} d \theta$
e $\int \frac{2 t^{3}-t}{\left(t^{2}+5\right)^{2}} d t$
$f \int \frac{2 t^{3}-t^{2}+t-3}{t(t-1)(t-2)^{2}} d t$

g. $\int \frac{t^{2}+1}{\left(t^{2}+2 t+3\right)^{2}} d t$

h. $\int \frac{\cos \cos x}{\sin ^{2} x-4 \sin \sin x-5} d x$ i. $\int \frac{e^{x}}{e^{2 x}+4} d x$

j. $\int \frac{x^{5}+2 x^{2}+1}{x^{3}+x} d x$

k. $\int \frac{t^{3}}{t^{2}-3 t+2} d t$

I. $\int \frac{5 \theta-4}{\theta^{2}-4 \theta} d \theta$

m. $\int \frac{2 t^{2}}{(t+1)^{3}} d t$

n. $\int \frac{1}{1+e^{x}} d x$

o. $\int \frac{\sec ^{2} \theta}{\tan ^{3} \theta-\tan ^{2} \theta} d \theta$

\subsection{INTEGRAL DENGAN SUBSITUSI}

Integral dengan teknik substitusi digunakan untuk mempermudah dalam pengerjaan integrasi. Tidak semua soal dapat dengan mudah dikerjakan, ada yang membutuhkan teknik substitusi terlebih dahulu untuk pengerjaan integral selanjutnya.

\section{SUBSTITUSI- $u$}

Metode substitusi bergantung pada rumus berikut, dengan $u$ merupakan suatu fungsi dari $x$ yang diferensiabel.

$\int\left[f(u) \frac{d u}{d x}\right] d x=\int f(u) d u$

Untuk memperlihatkan kebenaran dari rumus (5.3.1), maka dimisalkan $F$ sebagai anti turunan dari $f$, sehingga

$$
\frac{d}{d u}[F(u)]=f(u)
$$

$\int f(u) d u=F(u)+C$ 
Jika $u$ adalah fungsi dari $x$ yang diferensiabel, maka dengan aturan rantai

$$
\frac{d}{d x}[F(u)]=\frac{d}{d u}\left[F^{\prime}(u)\right] \frac{d u}{d x}=f(u) \frac{d u}{d x}
$$

Atau

$$
\int\left[f(u) \frac{d u}{d x}\right] d x=F(u)+C
$$

\section{Contoh 5.12 :}

Carilah $\int\left(x^{2}-2 x+1\right)^{25} \cdot(2 x-2) d x$

\section{Penyelesaian :}

Jika diambil $u=x^{2}-2 x+1$, maka $\frac{d u}{d x}=2 x-2 \rightarrow d x=\frac{d u}{2 x-2}$ sehingga integral yang diberikan dapat ditulis menjadi

$$
\begin{aligned}
& \int\left(x^{2}-2 x+1\right)^{25} \cdot(2 x-2) d x=\int(u)^{25}(2 x-2) \frac{d u}{(2 x-2)} \\
= & \int(u)^{25} d u \\
= & \frac{1}{26} u^{26}+C=\frac{\left(x^{2}-2 x+1\right)^{26}}{26}+C
\end{aligned}
$$

\section{Contoh 5.13 :}

Tentukan integral berikut $\int \cos \cos (3 x+1) d x$ !

\section{Penyelesaian :}

Misal $u=3 x+1$, sehingga $\frac{d u}{d x}=3$, dengan demikian 


$$
\begin{aligned}
& \int \cos \cos (3 x+1) d x=\int \cos \cos u d x=\int \cos \cos u \frac{d u}{3} \\
& =\frac{1}{3} \int \cos \cos u d u \frac{1}{3} \sin \sin u+C \\
& =\frac{1}{3} \sin \sin (3 x+1)+C
\end{aligned}
$$

\section{Contoh 5.14 :}

Selesaikan $\int \cos ^{2} x \sin \sin x d x$ !

\section{Penyelesaian :}

Misalkan $\quad u=\cos \cos x, \frac{d u}{d x}=(-\sin \sin x) \rightarrow d x=\frac{d u}{-\sin \sin x}$ dengan demikian

$\int \cos ^{2} x \sin \sin x d x=\int u^{2} \sin \sin x d x=\int u^{2} \sin \sin x \frac{d u}{-\sin \sin x}=\int u^{2} d u$

\section{Contoh 5.15 :}

Selesaikan $\int \frac{2 t}{\left(t^{2}+2\right)^{50}} d t$ !

\section{Penyelesaian :}

Misal $u=t^{2}+2, \frac{d u}{d t}=2 t \rightarrow d t=\frac{d u}{2 t}$ dengan demikian

$$
\int \frac{2 t}{\left(t^{2}+2\right)^{50}} d t=\int \frac{2 t}{u^{50}} d t=\int \frac{2 t}{u^{50}} \frac{d u}{2 t}=\int \frac{1}{u^{50}} d u=-\frac{1}{49 u^{49}}+C=-\frac{1}{49\left(t^{2}+2\right)^{49}}
$$

\section{SOAL LATIHAN}


1. Hitunglah integral dibawah ini dengan memilih substitusi yang ditunjukkan!

a. $\int 2 x^{2}\left(x^{3}+1\right)^{17} d x ; u=x^{3}+1$

b. $\int \frac{1}{\sqrt{x}} \sin \sin \sqrt{x} d x ; u=\sqrt{x}$

c. $\int \frac{3 x}{\sqrt{4 x^{2}+5}} d x ; u=4 x^{2}+5$

d. $\int \sec ^{2}(4 x+2) d x ; \quad u=4 x+2$

e. $\int(2 x+7)\left(x^{2}+7 x+3\right)^{2 / 3} d x ; u=x^{2}+7 x+3$

f. $\int x^{2}(1+x)^{1 / 2} d x ; u=(1+x)$

g. $\int(1+\cos \cos t)^{11} \sin \sin t d t ; u=1+\cos \cos t$

h. $\int \cot \cot x \csc ^{2} x d x ; u=\cot \cot x$

i. $\int \sqrt{\sin \sin \pi \theta} \cos \cos \pi \theta d \theta ; u=\sin \sin \pi \theta$

2. Hitunglah integral-integral berikut :
a. $\int \frac{2 t+2}{\left(t^{2}+2 t+3\right)^{2}} d t$
b. $\int \frac{\cos \cos x}{\sin ^{2} x-4 \sin \sin x-5} d x$
c. $\int \frac{e^{x}}{e^{2 x}+4} d x$
d. $\int \frac{3 x^{2}+1}{x^{3}+x} d x$
e. $\int \frac{2 t-3}{t^{2}-3 t+2} d t$
f. $\int \frac{2 \theta-4}{\theta^{2}-4 \theta} d \theta$ 

g. $\int \frac{2 t^{2}}{\left(t^{3}+1\right)^{3}} d t$
h. $\int \frac{\sin \sin x}{1+\cos \cos x} d x$
i. $\int \frac{\sec ^{2} \theta}{\tan ^{3} \theta-\tan ^{2} \theta} d \theta$

3. Hitung integralnya
a. $\int \frac{y}{\sqrt{y+1}} d y$
b. $\int \sin ^{3} 2 \theta d \theta$ (note : gunakan kesamaan

$$
\sin ^{2} x+\cos ^{2} x=1
$$

\subsection{INTEGRAL TERTENTU}

Pada bab sebelumnya dibahas mengenai antiturunan (integral tak tentu) melalui definisi luas. Dalam hal ini akan ditunjukkan cara menghitung luas dengan menggunakan limit dan akan dikembangkan suatu definisi luas dibawah suatu kurva.

\section{DEFINISI LUAS}

Menunjuk pada definisi pada Teorema 5.1.1 dan Teorema 5.1.2 bahwa integral $f(x)$ pada selang $[p, q]$ adalah luas di atas selang $[p, q]$, tetapi dibawah $y=f(x)$ dikurangi luas dibawah $[p, q]$ tetapi diatas $y=f(x)$ sehingga dapat didefiniskan dengan Gambar 5.2. berikut ini, dengan $S$ sebagai daerah yang ditanyakan luas daerahnya.

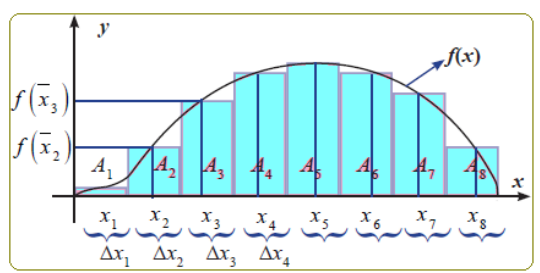

(a)

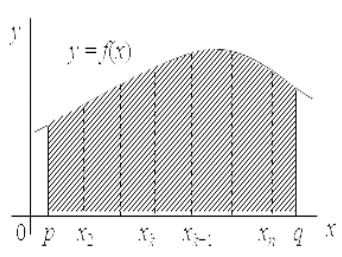

(b)

Gambar 5.4. Luas Kurva Dalam Selang $[p, q]$ 
Contoh 5.16: Hitunglah $\int_{0}^{2}(x-1) d x$ !

\section{Penyelesaian :}

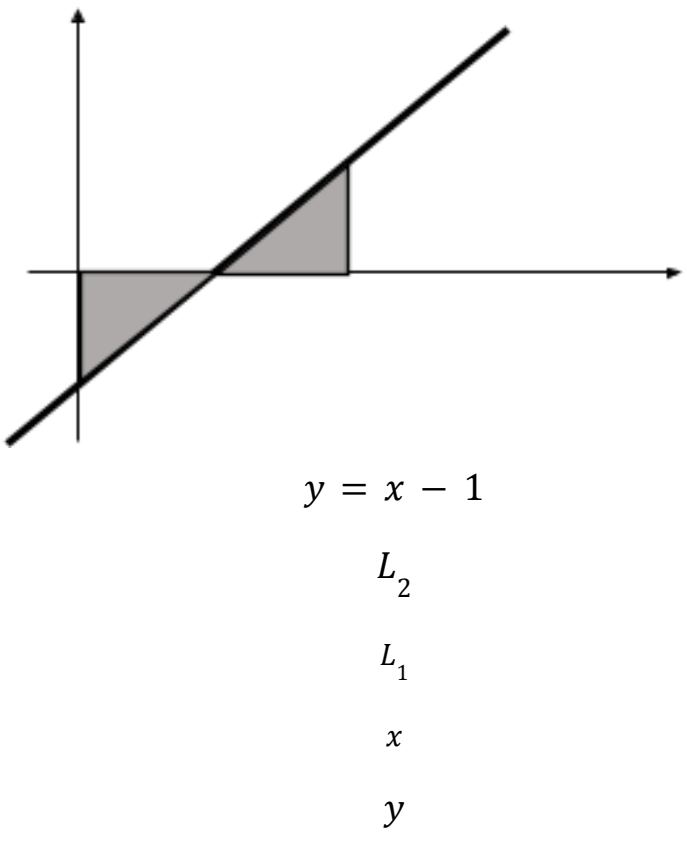

Gambar 5.5. Luas Bidang Geometri

Kurva berbentuk segitiga dengan alas berukuran 1 dan tinggi 1, sehingga luas segitiga dengan geometri bidang adalah $\frac{1}{2} \cdot a \cdot t=\frac{1}{2} \cdot 1 \cdot 1=\frac{1}{2}$, dengan demikian

$$
\int_{0}^{2}(x-1) d x=L_{1}+L_{2}=\frac{1}{2}+\left(-\frac{1}{2}\right)=0
$$

\section{Teorema 5.4.1}

1. Jika $a$ berada dalam domain $f$, maka didefiniskan

$$
\int_{a}^{a} f(x) d x=0
$$


2. Jika $f$ terintegral pada $[a, b]$, maka didefinisikan

$$
\int_{b}^{a} f(x) d x=-\int_{a}^{b} f(x) d x
$$

\section{SIFAT-SIFAT INTEGRAL TERTENTU}

Teorema 5.4.2. Sifat sifat integral tertentu berikut ini berdasarkan definisi integral tertentu.

- Jika $f$ dan $g$ terintegral pada $[a, b]$ dan jika $c$ suatu konstanta, maka $c f, f+g$, dan $f-g$ semuanya terintegral pada $[a, b]$ dan
a. $\quad \int_{a}^{b} c(f(x)) d x=c \int_{a}^{b} f(x) d x$
b. $\quad \int_{a}^{b}[f(x)+g(x)] d x=\int_{a}^{b} f(x) d x+\int_{a}^{b} g(x) d x$
c. $\quad \int_{a}^{b}[f(x)-g(x)] d x=\int_{a}^{b} f(x) d x-\int_{a}^{b} g(x) d x$

- $\quad$ Jika $f$ terintegral pada suatu selang tertutup yang memuat tiga titik a, b dan c, maka

$$
\int_{a}^{b} f(x) d x=\int_{a}^{c} f(x) d x+\int_{c}^{b} f(x) d x
$$

\section{Contoh 5.17 :}

Misalkan

$$
\int_{1}^{3} f(x) d x=2, \int_{-2}^{1} f(x) d x=5, \quad \int_{1}^{5} f(x)=-2, \int_{1}^{3} g(x) d x=-1
$$

Dapatkan 

a. $\int_{1}^{3}[3 f(x)+2 g(x)] d x$
b. $\quad \int_{-2}^{5} 3 f(x) d x$

\section{Penyelesaian :}

Penyelesaian (a). Dari Teorema 5.4.2

$$
\begin{aligned}
& \int_{1}^{3}[3 f(x)+2 g(x)] d x=3 \int_{1}^{3} f(x) d x+2 \int_{1}^{3} g(x) d x \\
& \quad=3(2)+2(-1)=4
\end{aligned}
$$

Penyelesaian (b). Dari Teorema 5.4.2 yang memuat a,b, dan c

$$
\begin{aligned}
\int_{-2}^{5} 3 f(x) d x & =3\left[\int_{-2}^{1} f(x) d x+\int_{1}^{5} f(x) d x\right] \\
& =3[5+(-2)]=9
\end{aligned}
$$

\section{SOAL LATIHAN}

1. Hitunglah integral tertentu berikut dengan menggunakan luas geometri bidang jika diperlukan!
a. $\int_{-2}^{0} x^{2} d x$
b. $\int_{0}^{2}(2-4 x) d x$
c. $\int_{0}^{2} \sqrt{4-x^{2}} d x$
d. $\int_{-2}^{1}|3 x-1| d x$
e. $\int_{1}^{3} 1-\frac{1}{2} x d x$
f. $\int_{-2}^{0} \sqrt{1+x^{2}} d x$
g. $\int_{0}^{\pi} \cos \cos x d x$
h. $\int_{0}^{\pi} \sin \sin x d x$
i. $\int_{0}^{3} x^{2}-4 d x$ 


\subsection{TEOREMA FUNDAMENTAL KALKULUS PERTAMA}

Dalam subbab sebelumnya, telah dibahas mengenai konsep integral tertentu tetapi belum dibahas mengenai bagaimana cara menghitungnya. Untuk menghitung integral tertentu ini, hal mendasar yang perlu diperhatikan adalah

\section{Teorema 5.5.1. Teorema Fundamental Kalkulus Pertama}

Jika $f$ kontinu pada $[a, b]$ dan $F$ adalah antiturunan dari $f$ pada $[a, b]$ , maka,

$$
\int_{a}^{b} f(x) d x=F(b)-F(a)
$$

\section{Contoh 5.18 :}

Hitunglah $\int_{0}^{2} x^{2} d x$ !

\section{Penyelesaian :}

Antiturunan atau integral dari $x^{2}$ adalah $\frac{1}{3} x^{3}$, jadi sesuai dengan Teorema 5.5.1

$$
\left.\int_{0}^{2} x d x=\frac{1}{3} x^{3}\right]_{0}^{2}=\frac{1}{3}\left(2^{3}\right)-\frac{1}{3}\left(0^{3}\right)=\frac{8}{3}
$$

\section{Contoh 5.19 :}

Gunakan Teorema Fundamental Kalkulus Pertama untuk menyelesaikan
a. $\int_{-1}^{2} x^{3}-3 x^{2}+3 x-1 d x$
b. $\quad \int_{1}^{3} x^{1 / 2}+\frac{1}{x^{2}} d x$ 


\section{Penyelesaian :}

Penyelesaian (a).

$$
\begin{aligned}
& \int_{-1}^{2} x^{3}-3 x^{2}+3 x-1 d x=\left[\frac{1}{4} x^{4}-x^{3}+\frac{3}{2} x^{2}-x\right]_{-1}^{2} \\
& \left(\frac{16}{4}-8+\frac{12}{2}-2\right)-\left(\frac{1}{4}+1+\frac{3}{2}+1\right)=(0)-\left(\frac{15}{4}\right)=-\frac{15}{4}
\end{aligned}
$$

Penyelesaian (b).

$$
\begin{aligned}
& \int_{1}^{3} x^{\frac{1}{2}}+\frac{1}{x^{2}} d x=\left[\frac{2}{3} x^{\frac{3}{2}}-\frac{1}{x}\right]_{1}^{3} \\
& =\left(\frac{2}{3}\left(3^{3 / 2}\right)-\frac{1}{3}\right)-\left(\frac{2}{3}\left(1^{\frac{3}{2}}\right)-1\right)=\frac{6}{3} \sqrt{3}
\end{aligned}
$$

\section{SOAL LATIHAN}

1. Hitung integral tertentu berikut menggunakan Teorema Fundamental Kalkulus Pertama
a. $\int_{-1}^{2} x^{3}-2 x d x$
b. $\int_{-1}^{1} x\left(x^{2}+1\right) d x$
c. $\int_{-2}^{0}\left(x^{2}-5 x+6\right) d x$
d. $\int_{1}^{2} \frac{1}{x^{8}} d x$
e. $\int_{0}^{4} x^{-3 / 5} d x$
f. $\int_{2}^{4} 2 y \sqrt{y} d y$
g. $\int_{1}^{4} u^{2}-u^{-\frac{3}{2}} d u$
h. $\int_{1}^{3}\left(2 x^{\frac{2}{3}}-3 x\right) d x$
i. $\int_{0}^{\pi / 4} \sec ^{2} \theta d \theta$
j. $\int_{0}^{\pi} \sin \sin \theta d \theta$
k. $\int_{-\pi / 4}^{\pi / 4} \cos \cos x d x$
I. $\int_{0}^{2}|3 x-2| d x$ 

m. $\int_{1}^{5}|x-2| d x$
n. $\int_{1}^{4} \frac{3}{\sqrt{x}}-5 \sqrt{x} d x$
o. $\int_{0}^{2} u^{3 / 2}-5 \sqrt{u^{3}+1} d u$

2. Gunakan Teorema 5.4.2 untuk menghitung integral-integral tertentu berikut :

a. $\quad \int_{-2}^{3} f(x) d x$ dengan $f(x)=\left\{-2 x^{2}-4 \quad x \geq 0 x<0\right.$

b. $\quad \int_{0}^{4} f(x) d x$ dengan $f(x)=\left\{\sqrt{x} 1 / x^{2} \quad 0 \leq x<1 x \geq 1\right.$

3. Hitunglah integral trigonometri berikut :

$$
\int_{\pi / 6}^{\pi / 2}\left(x+\frac{2}{\sin ^{2} x}\right) d x
$$

\subsection{TEOREMA FUNDAMENTAL KALKULUS KEDUA}

Pada Teorema Fundamental Kalkulus Pertama dibahas mengenai perhitungan integral dengan adanya batas bawah dan batas atas berupa nilai atau angka. Sedangkan pada Teorema Fundamental Kalkulus Kedua ini batasnya (salah satunya atau keduanya) berupa variabel atau peubah.

Untuk menghindari kesalahan dalam perhitungan, maka peubah dibuat berbeda dengan peubah integrasinya, misalkan

$$
\int_{a}^{x} f(x) d x
$$

dapat ditulis menjadi

$$
\int_{a}^{x} f(t) d t
$$

\section{Contoh 5.20 :}


Hitunglah $\int_{0}^{x} t^{2}-4 t d t$ !

\section{Penyelesaian :}

$$
\int_{0}^{x} t^{2}-4 t d t=\left[\frac{1}{3} t^{3}-2 t^{2}\right]_{0}^{x}=\frac{x^{3}}{3}-2 x^{2}
$$

Melihat Contoh 5.20, bahwa penyelesaian akhir bukan berupa nilai atau angka melainkan berupa fungsi dari $x$ saja.

\section{Teorema 5.6.1 . Teorema Fundamental Kalkulus Kedua}

Misal $f$ fungsi kontinu pada selang $I$, dan misal $a$ sebarang titik pada I. Jika $F$ didefinisikan dengan

$$
F(x)=\int_{a}^{x} f(t) d t
$$

Maka $F^{\prime}(x)=f(x)$ pada setiap titik $x$ pada selang $I$.

Teorema ini dapat disajikan dengan rumus :

$$
\frac{d}{d x}\left[\int_{a}^{x} f(t) d t\right]=f(x)
$$

Note : Apabila integrannya kontinu, turunan dari integral tertentu terhadap batas atasnya sama dengan nilai integran di batas atas tersebut.

\section{Contoh 5.21 :}

Kerana $f(x)=x^{3}$ suatu fungsi kontinu, berdasarkan rumus pada Teorema 5.6.1 bahwa 


$$
\frac{d}{d x}\left[\int_{1}^{x} t^{3} d t\right]=x^{3}
$$

Untuk memerikasa, dihitung integralnya, kemudian diturunkan :

$$
\int_{1}^{x} t^{3} d t=\left[\frac{t^{4}}{4}\right]_{t=1}^{x}=\frac{x^{4}}{4}-\frac{1}{4}
$$

Penurunan diatas menghasilkan $x^{3}$ seperti diatas.

\section{SOAL LATIHAN}

1. Diberikan $\int_{-1}^{5} f(x) d x=3$, dapatkan
a. $\int_{-1}^{5} f(t) d t$
b. $\int_{-1}^{5} f(u) d u$

2. Gunakan Teorema Fundamental Kalkulus Kedua untuk memperoleh turunannya!
a. $\frac{d}{d x} \int_{0}^{x} \frac{d t}{1+\sqrt{t}}$
b. $\frac{d}{d x} \int_{1}^{x} \sin \sin \sqrt{t} d t$
c. $\frac{d}{d x} \int_{0}^{x} \frac{t}{\cos \cos t} \mathrm{dt}$
d. $\frac{d}{d x} \int_{0}^{x} \frac{\cos \cos t}{t^{2}+3} d t$ 
Anton, H., CALCULUS. A New Horizon, $6^{\text {th }}$ edition. John Wiley \& Sons, Inc. New York, 1999.

Dosen Jurusan Matematika FMIPA ITS. Buku Ajar Kalkulus 2 Untuk Kalangan Sendiri. Surabaya: Jurusan Matematika FMIPA ITS Sukolilo Surabaya, 2000. $\int_{a}^{b}[f(x)-g(x)] d x$

Purcell, J.E., Dele Varberg.Kalkulus dan Geometri Analisa jilid 1. Jakarta: Erlangga.1999.

Purcell, J.E., Rigdon, S.E., CALCULUS, $8^{\text {th }}$ edition, Prentice-Hall, New Jersey, 2000.

Purwanto, Heri, dkk. KALKULUS. Jakarta: Biang Prestasi. 2005. 


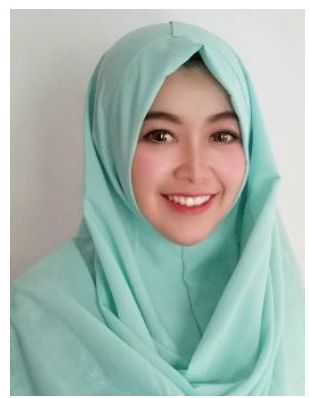

Nuril Lutvi Azizah, S.Si., M.Si. dilahirkan di Lumajang, 29 April 1989. Pada tahun 2011, penulis mendapatkan gelar Sarjana Sains Matematika dari Institut Teknologi Sepuluh Nopember Surabaya. Penulis melanjutkan studi S2 pada tahun yang sama yaitu tahun 2011 di Program Pascasarjana Matematika melalui beasiswa Freshgraduate dari Institut Teknologi Sepuluh Nopember Surabaya. Tahun 2013, penulis secara resmi mendapatkan gelar M.Si. Penulis mengawali karirnya sebagai Dosen tetap pada tahun 2015 di fakultas Teknik prodi Informatika Universitas Muhammadiyah Sidoarjo. Selain pendidikan dan pengajaran, penulis juga terlibat dalam penelitian dan pengabdian kepada masyarakat. Beberapa yang pernah dilakukan oleh penulis adalah tentang aplikasi matematika dalam bidang teknik dan penerapannya.

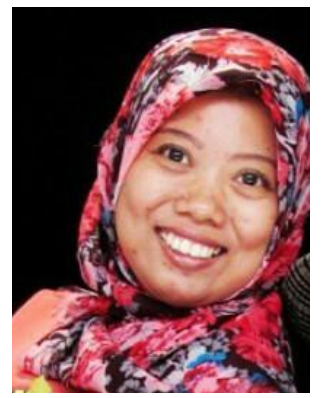

Novia Ariyanti, S.Si., M.Pd. lahir di Surabaya, 10 Nopember 1983. Lulus Sarjana Matematika Universitas Negeri Surabaya tahun 2007 dengan gelar S.Si. Penulis melanjutkan studi S2 di Prodi Pendidikan Matematika Program Pascasarjana Universitas Negeri Surabaya lulus tahun 2014 dengan gelar M.Pd. Karir pendidikan dan pengajaran dimulai tahun 2015 di fakultas Teknik Prodi Informatika Universitas Muhammadiyah Sidoarjo. Selain pengajaran, penulis juga ikut berperan serta dalam kegiatan penelitian dan pengabdian. Penulis juga aktif dalam mengikuti kegiatan-kegiatan penunjang akademik seperti seminar, workshop/ lokakarya, pelatihan dan kegiatan akademik lainnya. 